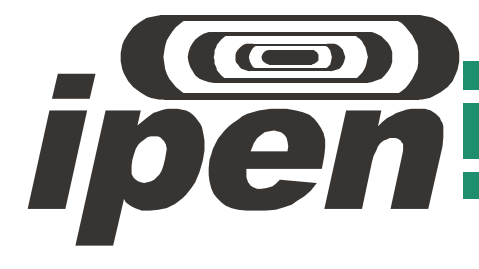

AUTARQUIA ASSOCIADA À UNIVERSIDADE DE SÃO PAULO

AVALIAÇÃO DO PROCESSO DE DESENVOLVIMENTO DE DESMINERALIZAÇÃO EM ESMALTE DENTAL HUMANO UTILIZANDO A TÉCNICA DE TOMOGRAFIA POR COERÊNCIA ÓPTICA

ANA CLAUDIA BALLET DE CARA

Dissertação apresentada como parte dos requisitos para obtenção do Grau de Mestre em Ciências na área de Tecnologia Nuclear - Materiais.

Orientador:

Prof. Dr. Anderson Zanardi de Freitas

São Paulo

2012 
IPEN - INSTITUTO DE PESQUISAS ENERGÉTICAS E NUCLEARES AUTARQUIA ASSOCIADA À UNIVERSIDADE DE SÃO PAULO

\author{
AVALIAÇÃO DO PROCESSO DE DESENVOLVIMENTO DE \\ DESMINERALIZAÇÃO EM ESMALTE DENTAL HUMANO UTILIZANDO A \\ TÉCNICA DE TOMOGRAFIA POR COERÊNCIA ÓPTICA
}

ANA CLAUDIA BALLET DE CARA

\begin{abstract}
Dissertação apresentada como parte dos requisitos para obtenção do Grau de Mestre em Ciências na área de Tecnologia Nuclear - Materiais.
\end{abstract}

Orientador:

Prof. Dr. Anderson Zanardi de Freitas

São Paulo

2012 


\section{DEDICATÓRIA}

Aos meus queridos pais (Felicio e Cleonice), por todo o carinho e empenho na nossa educação;

À minha avó Flávia (in memoriam), por estar sempre presente na minha vida;

À minha irmã Fabiana, meu exemplo de dedicação aos estudos;

Ao meu querido sobrinho Gabriel. 


\section{AGRADECIMENTOS}

À Deus, por estar sempre comigo, por seu infinito amor e bondade.

Ao meu orientador Dr. Anderson Zanardi de Freitas, pela paciência e dedicação, pelos ensinamentos transmitidos, pela amizade e pela participação sempre presente.

À Drª . Denise Maria Zezell, pela dedicação e carinho que teve comigo e por sua imensurável colaboração. Muito obrigada!

À Drâ. Patricia Aparecida da Ana, por sua disposição em ajudar-me desde a minha chegada ao IPEN, pela amizade e pelos vários dias que me auxiliou na realização dos experimentos.

Ao Instituto de Pesquisas Energéticas e Nucleares (IPEN) e ao Centro de Lasers e Aplicações (CLA), por permitir a utilização de seus equipamentos e dependências.

À Fundação de Amparo a Pesquisa do Estado de São Paulo (FAPESP) pelo suporte financeiro e pela bolsa concedida.

À Drª . Gláucia Bueno Benedetti Berbel, por sua amizade e pelas muitas análises estatísticas.

A Daniel Rosa Franzini, por ter me ajudado durante todo o curso da pósgraduação com os infindáveis cálculos e planilhas. Obrigada pela paciência, carinho e dedicação.

Aos amigos do Laboratório de Biofotônica, Carol, Cláudia, Marcelo, Moisés, Paulo, Thiago e Viviane, pelo convívio agradável e pela ajuda com a realização dos experimentos.

Ao técnico do Laboratório de Biofotônica, Valdir de Oliveira, pelo auxílio e pela consideração com os usuários do laboratório e pelos lanchinhos da tarde que muitas vezes oferece aos alunos.

Aos amigos do Laboratório de Tomografia por Coerência Óptica, Danilo, Marcello e Marcus, pela colaboração. 
Aos Srs. Luís e Rubens, que além de nos receberem bem todos os dias, ajudaram-me com as trocas de soluções das amostras aos finais de semana. Muito obrigada!

Ao Dr. Marcos Scapim, pelo auxílio com o preparo das soluções empregadas no estudo.

Ao meu tio João (in memoriam), por ter cuidado dos sobrinhos como se fossem seus filhos e a Daniel Barbosa pela colaboração.

Aos meus queridos amigos da pós-graduação, Débora, Leticia, Danilo, Ivanildo e Renato Ribamar, por serem meus amigos de todas as horas.

Aos meus amigos do Centro de Lasers e Aplicações, Mateus, Rosa, Tânia, IIKa, Renato, Eliane, Walter, Ediliene, Rosa , Andréia e Lídia.

A todos os amigos e funcionários do Centro de Lasers e Aplicações que contribuíram de alguma forma para a realização desse trabalho.

A todos os meus professores, que desde a infância participaram da minha formação. 


\title{
AVALIAÇÃO DO PROCESSO DE DESENVOLVIMENTO DE DESMINERALIZAÇÃO EM ESMALTE DENTAL HUMANO UTILIZANDO A TÉCNICA DE TOMOGRAFIA POR COERÊNCIA ÓPTICA
}

\author{
ANA CLAUDIA BALLET DE CARA
}

\section{RESUMO}

A detecção de lesões cariosas nos estágios iniciais possibilita a escolha de tratamentos baseados na preservação da estrutura dental. Dessa forma, a utilização de exames capazes de diagnosticar precocemente essas lesões, como a Tomografia por Coerência Óptica (OCT - Optical Coherence Tomography) é adequada. Assim, o objetivo do trabalho foi avaliar a capacidade da OCT em quantificar os estágios de desmineralização do esmalte durante o desenvolvimento de lesões simuladas de cárie, tendo como padrão de referência o teste de microdureza seccional. Foram utilizados 53 dentes terceiros molares hígidos, os quais tiveram as coroas seccionadas para obtenção de 210 amostras. Para avaliar as possíveis alterações sofridas por cada amostra, essas foram examinadas através da técnica de OCT no início do experimento e novamente examinadas após o término do período de ciclagem estabelecido para cada grupo, utilizando os coeficientes de atenuação óptica total e o cálculo de área em gráficos de intensidade de sinal de OCT, como parâmetros de análise. Posteriormente, as amostras foram submetidas a testes de microdureza seccional. A diferença entre os coeficientes de atenuação óptica obtidos antes e depois da ciclagem de $\mathrm{pH}$ apresentou elevado grau de correlação com os resultados de microdureza seccional. Por meio da análise das áreas provenientes de gráficos de intensidade de sinal de OCT e microdureza Knoop, ambos em função da profundidade, foi observada relação de linearidade entre os resultados e elevada correlação entre as técnicas avaliadas $(\rho=0,99)$. De acordo com os resultados, a técnica de OCT foi capaz de detectar diferentes graus de desmineralização do esmalte dental humano em lesões simuladas de cárie. 


\title{
HUMAN DENTAL ENAMEL DEMINERALIZATION PROCESS ASSESSMENT USING THE OPTICAL COHERENCE TOMOGRAPHY TECHNIQUE
}

\author{
ANA CLAUDIA BALLET DE CARA
}

\begin{abstract}
The detection of carious lesions in early stages enables treatment choose based on dental structure preservation. This way, the utilization of exams capable of early diagnosis of these lesions, like OCT (Optical Coherence Tomography), is appropriate. Therefore, the objective of this work was to assess the capability of OCT in quantifying the enamel demineralization stages during the development of simulated caries lesions, having as reference standard the sectional microhardness test. There were used 53 sound third molars, which had their crowns sectioned to obtain 210 samples. To assess possible changes in each sample, these were examined by the OCT technique in the beginning of the experiment and again in the end of the cycling period established to each group, using the total optical attenuation coefficient and the area calculations using OCT signal intensity as analysis parameters. After that, the samples were submitted to sectional microhardness test. The difference between optical attenuation coefficients taken before and after the $\mathrm{pH}$ cycling, showed a high level of correlation with the microhardness results. Through areas analysis of OCT signal intensity and Knoop microhardness against depth, it was observed linearity relation between results and high correlation among assessed techniques $(\rho=0,99)$. According to the results, the OCT technique was capable of detecting different degrees of demineralization of the human enamel in carious simulated lesions.
\end{abstract}




\section{SUMÁRIO}

1. INTRODUÇÃO__ 14

2. OBJETIVOS__ 17

3. FUNDAMENTOS TEÓRICOS __ 18

3.1 Estrutura do esmalte dental ___ 18

3.2 Processo de desmineralização do esmalte dental humano ___ 19

3.3 Tomografia por coerência óptica (OCT)___ 21

3.4 Microdureza seccional ___ 24

4. MATERIAIS E MÉTODOS__ 26

4.1 Delineamento experimental ___ 26

4.2 Preparação das amostras __ 27

4.3 Simulação do desafio cariogênico in vitro ___ 29

4.4 Exame das amostras através do emprego da Tomografia por Coerência Óptica (OCT) _ 33

4.5 Avaliação das amostras por teste de microdureza seccional___ 36

5. RESULTADOS E DISCUSSÃO___ 41

5.1 Resultados do Experimento Piloto ___ 41

5.1.1 Resultados de OCT__ 41

5.1.2 Resultados de Microdureza Seccional ___ 44

5.1.3 Comparação entre os resultados de OCT e Microdureza seccional ___ 50

5.2 Resultados do Experimento Final __ 57

5.2.1 Resultados de OCT__ 58

5.2.2 Resultados de Microdureza seccional___ 69

5.2.3 Comparação entre os resultados de OCT e Microdureza seccional ___ 73

6. CONCLUSÕES _ 83

7. APÊNCICES _ 84

7.1 Apêndice A__ 84

7.2 Apêndice $B$

7.3 Apêndice $C$

REFERÊNCIAS BIBLIOGRÁFICAS___ 87 


\section{Lista de figuras}

FIGURA 1: Processos de desmineralização e remineralização do esmalte dental na presença de biofilme. Para valores de $\mathrm{pH}$ abaixo de 5,5 ocorre desmineralização e para valores acima deste, há predomínio do processo inverso.

FIGURA 2: llustração esquemática de um arranjo OCT. A fonte ilumina os dois braços do interferômetro. A posição do espelho de referência determina a profundidade a ser "observada" na amostra pelo tempo de vôo dos fótons. Junto ao detector, está ilustrada a formação de uma imagem OCT. A linha curva projeta o tamanho do braço de referência sobre o braço da amostra, e relaciona ambos com a imagem formada.

FIGURA 3: Interface do programa associado ao microdurômetro para obtenção dos valores de dureza Knoop. As linhas (em vermelho) são posicionadas nas extremidades da indentação e, então, o valor de dureza é fornecido automaticamente (no exemplo, o valor é $460 \mathrm{Kgf.mm}^{-2}$ ). 24

FIGURA 4: Esquema do delineamento experimental. 27

FIGURA 5: Esquema de corte da coroa dental para obtenção das amostras. Os planos de secção estão indicados pelas linhas azuis.

FIGURA 6: Posicionamento das amostras nas placas utilizadas para o exame de OCT.

FIGURA 7: Fotografia de caixa para armazenamento refrigerado, com amostras cobertas por algodão umedecido em água Milli-Q. .29

FIGURA 8: Tubos acondicionados em suportes acrílicos para ciclagem de $\mathrm{pH}$...32 FIGURA 9: Suporte das amostras para ciclagem de $\mathrm{pH}$. Os fios ortodônticos contendo as amostra fixadas nas extremidades, presos a haste metálica por alças confeccionadas nos fios.

FIGURA 10: Fotografia do equipamento de OCT para exame das amostras. .......33

FIGURA 11: Região central utilizada para análise dos dados de OCT.

FIGURA 12: Interface do programa utilizado para análise das imagens. 35

FIGURA 13: Amostra fixada com cera pegajosa à placa acrílica para secção. ....37 FIGURA 14: Imagem do equipamento utilizado para secção das amostras em fatias. 
FIGURA 15: Equipamentos utilizados para embutir (a) e polir amostras (b) para exame de microdureza seccional.

FIGURA 16 - Preparo das amostras para teste de microdureza. a) Planos de secção empregados para obtenção de fatias a serem analisadas por microdureza.

b) Amostra preparada para avaliação por microdureza seccional.

FIGURA 17: Equipamento utilizado para realizar os testes de microdureza seccional Knoop.

FIGURA 18: Sequência de indentações. Observa-se a presença de 3 colunas e maior distância entre as indentações de uma mesma coluna a partir da profundidade de $100 \mu \mathrm{m}$ com relação à borda de esmalte dental.

FIGURA 19- Imagens de OCT para as amostras sadia (a) e desmineralizada após 15 dias de ciclagem (b).

FIGURA 20: Gráfico dos coeficientes de atenuação óptica em função dos grupos antes (controle) e após a desmineralização provocada pela ciclagem de $\mathrm{pH}$. $\mathrm{O}$ sinal negativo das medidas indica o decaimento exponencial da intensidade do sinal de OCT.

FIGURA 21: Gráfico da diferença entre os coeficientes de atenuação obtidos antes e depois da simulação do desafio cariogênico, para cada um dos grupos avaliados.

FIGURA 22: Gráfico dos valores de microdureza em função da profundidade das indentações no esmalte dental, para a amostra 6 do grupo 3 . 46

FIGURA 23: Gráfico dos valores médios de microdureza em função da profundidade para os grupos de análise. Maior variação dos valores de microdureza é observada até a profundidade de $120 \mu \mathrm{m}$.

FIGURA 24: Média de valores de microdureza seccional de cada um dos grupos, para profundidades de 10 a $120 \mu \mathrm{m}$

FIGURA 25: Valores de microdureza em função da profundidade para amostra 1 do grupo 4. A área contida entre a linha preta (valor médio de microdureza da região saudável) e a linha vermelha (valores de microdureza para regiões desmineralizadas) representa o conteúdo mineral perdido pela amostra após desafio cariogênico. 
FIGURA 26 - Desmineralização obtida pela diferença de áreas sobre e sob a curva em gráficos de microdureza por profundidade, para cada grupo. Maior perda mineral foi observada no grupo 4 . 50

FIGURA 27: Resultados médios de microdureza seccional obtidos até a profundidade de $120 \mu \mathrm{m}$ e de coeficientes de atenuação óptica normalizados pelo maior valor apresentados para cada técnica. .51

FIGURA 28: Comparação entre os resultados provenientes de testes de microdureza seccional e de OCT, para avaliação de conteúdo de perda mineral.52 FIGURA 29: Resultados médios de microdureza seccional obtidos até a profundidade de $120 \mu \mathrm{m}$ e de coeficiente de atenuação óptica para a profundidade de 40 a $700 \mu \mathrm{m}$. O sinal negativo associado aos valores de coeficiente de atenuação óptica refere-se ao decaimento exponencial da intensidade do sinal de OCT. .53

FIGURA 30: Comparação entre os resultados provenientes de testes de microdureza seccional, para a profundidade de 10 a $120 \mu \mathrm{m}$ e de OCT de 40 a $700 \mu \mathrm{m}$, para avaliação de conteúdo de perda mineral. .54 FIGURA 31: Valores médios de microdureza seccional e de coeficiente de atenuação óptica total, para a profundidade de 40 a $120 \mu \mathrm{m}$. O sinal negativo associado aos valores de coeficiente de atenuação óptica refere-se ao decaimento exponencial da intensidade do sinal de OCT. .55 FIGURA 32: Comparação entre os resultados provenientes de testes de microdureza seccional e OCT, ambos para a profundidade de 40 a $120 \mu \mathrm{m}$ para avaliação de alteração de conteúdo de perda mineral. 56 FIGURA 33: a) Sinal original do OCT em dB, b) Sinal de OCT corrigido para a linha base. .57

FIGURA 34: Valores do coeficiente de atenuação óptica para diferentes profundidades de análise, para todos os grupos estudados. O sinal negativo dos valores representa o decaimento exponencial da amplitude do sinal elétrico da OCT.

FIGURA 35: Gráfico dos coeficientes de atenuação óptica em função dos grupos antes (controle) e após a desmineralização provocada pela ciclagem de $\mathrm{pH}$. A profundidade avaliada nas amostras foi de 40 a $120 \mu \mathrm{m}$. O sinal negativo das medidas indica o decaimento exponencial da intensidade do sinal de OCT. 60 
FIGURA 36: Gráfico da diferença entre os coeficientes de atenuação obtidos antes e depois da simulação do desafio cariogênico, para cada um dos grupos avaliados. A profundidade das amostras analisadas foi de 40 a $120 \mu \mathrm{m}$.

FIGURA 37: Distribuição dos valores de coeficiente de atenuação óptica total, obtidos a partir da análise da profundidade de 40 a $120 \mu \mathrm{m}$. A linha verde representa o valor do limiar de coeficiente de atenuação óptica de $2,67 \mathrm{E}^{-2} \mu \mathrm{m}^{-1}$. O sinal negativo associado aos valores de coeficiente de atenuação óptica refere-se ao decaimento exponencial da intensidade do sinal de OCT. 62 FIGURA 38: Gráfico de intensidade de sinal de OCT em função da profundidade, para cada um dos grupos de análise, após a simulação do desafio cariogênico..63 FIGURA 39: Gráfico dos coeficientes de atenuação óptica antes e após a ciclagem de $\mathrm{pH}$, para a profundidade de $25 \mathrm{a} 120 \mu \mathrm{m}$. O sinal negativo associado aos valores de coeficiente de atenuação óptica refere-se ao decaimento exponencial da intensidade do sinal de OCT.

FIGURA 40: Gráfico da diferença entre os coeficientes de atenuação obtidos antes e depois da simulação do desafio cariogênico, para a profundidade de análise de 25 a $120 \mu \mathrm{m}$

FIGURA 41: Distribuição dos valores de coeficiente de atenuação óptica total, obtidos a partir da análise da profundidade de 25 a $120 \mu \mathrm{m}$. A linha verde representa o valor do limiar de coeficiente de atenuação óptica de $2,74 \mathrm{E}^{-2} \mu \mathrm{m}^{-1}$. O sinal negativo associado aos valores de coeficiente de atenuação óptica refere-se ao decaimento exponencial da intensidade do sinal de OCT. 66

FIGURA 42: Gráfico da intensidade do sinal médio de OCT em função da profundidade para o grupo 1. As regiões demarcadas correspondem às áreas analisadas.

FIGURA 43: Área sob a curva para a profundidade de 25 a $120 \mu \mathrm{m}$, obtida a partir do gráfico de sinal de OCT por profundidade, para cada um dos grupos avaliados.

FIGURA 44: Área sob a curva para a profundidade de 40 a $120 \mu \mathrm{m}$, obtida a partir do gráfico de sinal de OCT por profundidade, para cada um dos grupos avaliados. 
FIGURA 45: Gráfico dos valores médios de microdureza em função da profundidade para os grupos de análise. Maior variação dos valores de microdureza é observada até a profundidade de $120 \mu \mathrm{m}$. .70

Figura 46: Média de valores de microdureza seccional de cada grupo, para profundidades de 25 a $120 \mu \mathrm{m}$ e 40 a $120 \mu \mathrm{m}$ .71

FIGURA 47: Valores de microdureza em função da profundidade para amostra 2 do grupo 3. A área contida entre a linha vermelha (valor médio de microdureza da região saudável) e a linha preta (valores de microdureza para regiões desmineralizadas) representa o conteúdo mineral perdido pela amostra após desafio cariogênico, para as profundidades de 20 a $120 \mu \mathrm{m}$ (hachurado em verde) de 40 a $120 \mu \mathrm{m}$ (azul).

FIGURA 48: Valores de área relacionada à perda mineral obtidos pela diferença de áreas sob a curva da região sadia e desmineralizada em gráficos de microdureza por profundidade, para cada grupo. Maior valor de área relativa à perda mineral é observada no grupo 3 , submetido ao maior tempo de ciclagem de $\mathrm{pH}$. .73

FIGURA 49: Resultados médios de microdureza e de coeficiente de atenuação óptica para a profundidade de 40 a $120 \mu \mathrm{m}$. O sinal negativo associado aos valores de coeficiente de atenuação óptica refere-se ao decaimento exponencial da intensidade do sinal de OCT. .74 FIGURA 50: Resultados médios de microdureza e de coeficiente de atenuação óptica para a profundidade de 25 a $120 \mu \mathrm{m}$. O sinal negativo associado aos valores de coeficiente de atenuação óptica refere-se ao decaimento exponencial da intensidade do sinal de OCT. .75

FIGURA 51: Comparação entre os resultados provenientes de testes de microdureza seccional e de OCT, para avaliação de alteração do conteúdo mineral, para a profundidade de análise de 40 a $120 \mu \mathrm{m}$ em esmalte dental.......76 FIGURA 52: Comparação entre os resultados provenientes de testes de microdureza seccional e de OCT, para avaliação de alteração do conteúdo mineral, para a profundidade de análise de $20 \mu \mathrm{m}$ (para microdureza) ou $25 \mu \mathrm{m}$ (para OCT) a $120 \mu \mathrm{m}$ em esmalte dental. 
FIGURA 53: Comparação entre as áreas, obtidas, respectivamente, a partir de gráficos de microdureza e de intensidade do sinal de OCT, ambos em função da profundidade, em relação ao tempo de ciclagem de $\mathrm{pH}$ de cada grupo. As áreas comparadas referem-se à profundidade de 20 a $120 \mu \mathrm{m}$ para microdureza e de 25 a $120 \mu \mathrm{m}$ para OCT. As barras de erro representam o erro padrão. .....................78 FIGURA 54: Comparação entre as áreas obtidas a partir de gráficos de microdureza e de intensidade do sinal de OCT, ambos em função da profundidade, em relação ao tempo de ciclagem de $\mathrm{pH}$ de cada grupo. As áreas comparadas referem-se à profundidade de 40 a $120 \mu \mathrm{m}$ para microdureza e OCT. As barras de erro representam o erro padrão. .79 FIGURA 55: Gráfico de área sob a curva de OCT em função da diferença de áreas de microdureza entre a região sadia e desmineralizada (relacionada à perda mineral) para a profundidade aproximada de 20 a $120 \mu \mathrm{m}$ em esmalte dental. A linha vermelha representa a relação linear entre as técnicas avaliadas. .80

FIGURA 56: Gráfico de área sob a curva de OCT em função da diferença de áreas de microdureza entre a região sadia e desmineralizada (relacionada à perda mineral), para a profundidade de 40 a $120 \mu \mathrm{m}$ em esmalte dental. A linha vermelha representa a relação linear entre as técnicas avaliadas. .81 


\section{INTRODUÇÃO}

O diagnóstico precoce de lesões cariosas possibilita a adoção de procedimentos conservadores no tratamento da estrutura dental, visando estabilizar ou reverter as lesões, como terapia com flúor, antibacterianos, mudanças nos hábitos alimentares e de higiene, além da terapia com laser de baixa potência, o que, dessa forma, evita o enfraquecimento do elemento dental causado pela intervenção cirúrgico-restauradora".

Várias técnicas diagnósticas têm sido desenvolvidas para detecção de cáries incipientes, uma vez que os métodos visual-táctil e radiográfico apresentam-se limitados para esta aplicação ${ }^{2,3}$. Dentre essas técnicas, destacamse as que se baseiam em princípios ópticos, como espalhamento da luz (DiFOTI $\AA$, QLF e OCT) e fluorescência (DIAGNOdent $\left.{ }^{4}\right)^{4}$. O método de transiluminação por fibra óptica, comercializado sob o nome DiFOTI, caracterizase pela emissão de luz branca de alta intensidade sobre a estrutura dental e as regiões desmineralizadas aparecem como áreas escuras devido ao maior espalhamento da luz. Sua utilização é limitada pela impossibilidade de quantificação da intensidade da luz espalhada, logo, a análise é subjetiva ${ }^{5}$. O DIAGNOdent@ utiliza luz para fluorescer as porfirinas bacterianas, não permitindo verificar a severidade das lesões, já que a avaliação é indireta. Além disso, esse método apresenta a quantidade de resultados falso-positivos como outro inconveniente à sua aplicação prática ${ }^{4,6}$. Através do emprego da Fluorescência Quantitativa Induzida por Luz (QLF - Quantitative Light-induced Fluorescence) é possível quantificar a perda mineral do esmalte, por diminuição da sua fluorescência, porém, a presença de placa bacteriana ou saliva interfere nos resultados $^{7}$ e não permite avaliar as faces interproximais dos dentes ${ }^{4}$.

Considerando as limitações dos métodos diagnósticos acima descritos, vários estudos têm apresentado a Tomografia por Coerência Óptica (OCT Optical Coherence Tomography), como uma alternativa para detecção de cáries em estágios iniciais ${ }^{4,7,8}$. A OCT caracteriza-se por ser uma técnica não invasiva e não ionizante que fornece imagens seccionais de alta resolução de estruturas espalhadoras de luz, em tempo real ${ }^{9}$. 
A técnica de OCT aplicada a tecidos biológicos foi descrita inicialmente por Huang et al. ${ }^{10}$ e teve como precursor a Reflectometria Óptica no domínio da Coerência (OCDR - Optical Coherence Domain Reflectometry) utilizada na detecção de falhas em fibras ópticas ${ }^{11}$.

A oftalmologia é uma das principais aplicações clínicas da técnica de OCT, para análise de alterações na retina, uma vez que as estruturas transparentes do olho favorecem a penetração da luz e a chegada de luz retroespalhada por esse tipo de tecido ao detector, além de ser ainda hoje a única técnica capaz de realizar imagens de altíssima resolução das camadas internas da retina ${ }^{10}$. A OCT também é empregada na dermatologia para análise da subsuperfície da pele ${ }^{12,13}$, na gastroenterologia, para obter imagens da mucosa do trato gastro-intestinal ${ }^{14}$, para biópsia óptica ${ }^{15}$ e na odontologia para avaliação de tecidos moles e duros da cavidade bucal ${ }^{9,48}$, assim como no diagnóstico de alterações de esmalte, fraturas dentais, falhas de restaurações, doença periodontal e patologias de tecido mole ${ }^{48}$.

A capacidade diagnóstica da OCT para lesões simuladas de cárie tem sido reportada em vários estudos ${ }^{7,8,16,17,18,19,20}$, muitos deles utilizando uma variação da técnica convencional, denominada Tomografia por Coerência Óptica Sensível à Polarização (PS-OCT) ${ }^{16,17,18}$. Essa técnica utiliza uma fonte geradora de luz linearmente polarizada e detecta a radiação refletida em dois estados de polarização ortogonais ${ }^{9,21}$. Seu emprego permite melhor visualização da camada mais externa do esmalte, uma vez que, através da escolha da polarização, a reflexão na superfície pode ser controlada melhorando o contraste da imagem ${ }^{2,9}$, 22. Para análise in vitro de desmineralização de esmalte dental é importante que a superfície do mesmo seja mantida íntegra para simular as alterações iniciais que ocorrem durante o processo de desenvolvimento da cárie em meio bucal. $O$ modelo de ciclagem de $\mathrm{pH}$ descrito por Featherstone et al. (1986) ${ }^{23}$ é bastante utilizado para simular cáries em dentes humanos para análise através da OCT $^{16,17}$. Em 2003, Argenta et al..$^{24}$ sugeriram modificações deste modelo como forma de evitar a erosão da superfície e assim possibilitar a avaliação de alterações nesta região.

O potencial da técnica de OCT em mensurar o grau de mineralização da estrutura dental é um fator relevante para seu emprego no estudo de lesões 
cariosas, pois permite avaliar a severidade e evolução destas lesões ${ }^{17}$. Amaechi et al.(2003) ${ }^{17}$, compararam a técnica de OCT e QLF para quantificação de perda mineral em esmalte dental bovino e encontraram alta correlação entre os métodos analisados. Jones e Fried (2006) ${ }^{22}$ observaram que a OCT também é capaz de detectar os ganhos minerais, promovidos por procedimentos de remineralização do esmalte, através da diminuição da refletividade. No entanto, estes estudos não fizeram comparação entre os sinais de intensidade de luz retroespalhada da OCT com alterações minerais detectadas por ensaios de microdureza transversal. A dureza Knoop é um método bem estabelecido para avaliar alterações minerais em esmalte e dentina, sendo utilizada em vários estudos in vitro ${ }^{24,25,26,27}$ já que o grau de mineralização da estrutura está relacionado ao valor da medida de dureza obtido. Desse modo, o objetivo deste trabalho foi avaliar a correlação entre os valores encontrados para os testes de microdureza, durante diferentes níveis de desmineralização dental a que os dentes foram submetidos, com a capacidade da técnica de OCT em quantificar o grau de desmineralização dos mesmos. 


\section{OBJETIVOS}

O objetivo do trabalho foi avaliar a capacidade da técnica de tomografia por coerência óptica em detectar diferentes estágios de desmineralização do esmalte dental humano, tendo como método de comparação o teste de microdureza seccional e identificar um padrão de comportamento do sinal de espalhamento da luz por OCT para o esmalte desmineralizado, correlacionando-o com a perda mineral determinada pela técnica de microdureza seccional. 


\section{FUNDAMENTOS TEÓRICOS}

\subsection{Estrutura do esmalte dental}

O esmalte dental é o tecido mais mineralizado do organismo, constituído por aproximadamente $97 \%$ de material inorgânico representado, sobretudo por cristais de apatita. O conteúdo mineral é responsável por propriedades como a elevada dureza e translucide $z^{28}$.

Os cristais de apatita apresentam-se geralmente na forma de hidroxiapatita $\left[\mathrm{Ca}_{10}\left(\mathrm{PO}_{4}\right)_{6}(\mathrm{OH})_{2}\right]$, contendo carbonatos, sódio, magnésio, cloreto, potássio e flúor, entre outros ${ }^{29}$. A maior parte da inclusão desses íons nos cristais de apatita ocorre por substituição de radicais hidroxila, sendo que $30 \%$ desses são substituídos por carbonatos, acarretando o aumento da solubilidade da apatita $^{30}$. Quando ocorre substituição dos íons hidroxila por íons flúor, há diminuição da solubilidade dos cristais por formação de fluorhidroxiapatita ou hidroxiapatitas fluoretadas ${ }^{31}$.

Os cristais de hidroxiapatita apresentam-se na forma de bastões, com aproximadamente $50 \mathrm{~nm}$ de largura e $25 \mathrm{~nm}$ a $1 \mathrm{~mm}$ de comprimento. $O$ grupamento de cerca de 1000 cristais compõe os prismas de esmalte, representando a maior parte da estrutura do esmalte dental ${ }^{32}$.

Quanto à sua estrutura, o esmalte dental pode ser prismático ou aprismático. No processo de formação do esmalte, a secreção de matriz orgânica pelos ameloblastos é seguida por deposição de cristais de hidroxiapatita diretamente sobre a dentina, perpendicularmente à superfície da mesma, constituindo uma camada aprismática de aproximadamente $30 \mu \mathrm{m}$ de espessura). Após a formação dessa camada de esmalte, a secreção de matriz orgânica e a consequente mineralização é guiada pelos prolongamentos do citoplasma dos ameloblastos, chamados processos de Tomes, formando-se o esmalte prismático. Ao término da fase secretora, ainda pode ocorrer a formação de mais algumas camadas de esmalte superficial, novamente aprismático, devido à involução do processo de Tomes $^{28}$.

A porção prismática do esmalte apresenta os cristais de hidroxiapatita dispostos paralelamente ao longo eixo de cada prisma na sua porção central e inclinados em direção à periferia desses ${ }^{33}$. Transversalmente, os prismas 
apresentam forma de buraco de fechadura, com aproximadamente 4-5 $\mu \mathrm{m}$ de diâmetro, com distância de $0,1 \mu \mathrm{m}$ entre eles, que correspondem aos espaços interprismáticos ${ }^{32}$. Os espaços interprismáticos e intraprismáticos (espaços de 1-2 $\mathrm{nm}$ entre os cristais de hidroxiapatita) são preenchidos por água e material orgânico, e representam as principais vias de difusão do esmalte dental ${ }^{34}$.

\subsection{Processo de desmineralização do esmalte dental humano}

A troca de minerais entre o esmalte dental e o meio bucal ocorre frequentemente, devido a alterações de acidez do meio. Quando o pH do meio circundante ao esmalte está abaixo de 5,5 , considerado valor crítico para as trocas minerais do esmalte dental, ocorre a dissolução de cristais de hidroxiapatita e consequente perda de minerais do esmalte dental (desmineralização). Quando o pH está acima do valor crítico, ocorre o processo de remineralização do esmalte, por deposição de minerais na estrutura dental ${ }^{24,35}$.

Sucessivos processos de desmineralização e remineralização, com predomínio de perdas minerais é observado no desenvolvimento da cárie dental, que se caracteriza pela destruição da estrutura dental, sendo a doença mais prevalente da cavidade oral ${ }^{35}$.

A presença de biofilme dental é necessária para o desenvolvimento de lesões de cárie. O biofilme origina-se a partir da adsorção de proteínas salivares, lipídeos e componentes do fluido gengival sobre a superfície do dente, formando uma película, conhecida por película adquirida ${ }^{36}$. A película é então inicialmente colonizada por bactérias, dentre elas Streptococcus sanguis e oralis, que propiciam condições de colonização por bactérias cariogênicas, como Streptococcus mutans e sobrinus, além de Lactobacillus $^{37}$. A ingestão de carboidratos fermentáveis (sacarose, glicose, frutose, lactose, etc) é acompanhada pelo aumento da acidez do biofilme aderido à superfície dental, devido à metabolização desses carboidratos pelas bactérias cariogênicas, com consequente formação de ácido láctico, acético, fórmico e butírico ${ }^{33,37}$. Os ácidos produzidos se difundem para o interior do esmalte, ocasionando dissolução parcial dos cristais de hidroxiapatita e consequentemente a perda de Cálcio e Fosfato para o biofilme ${ }^{38}$ (FIGURA 1). 


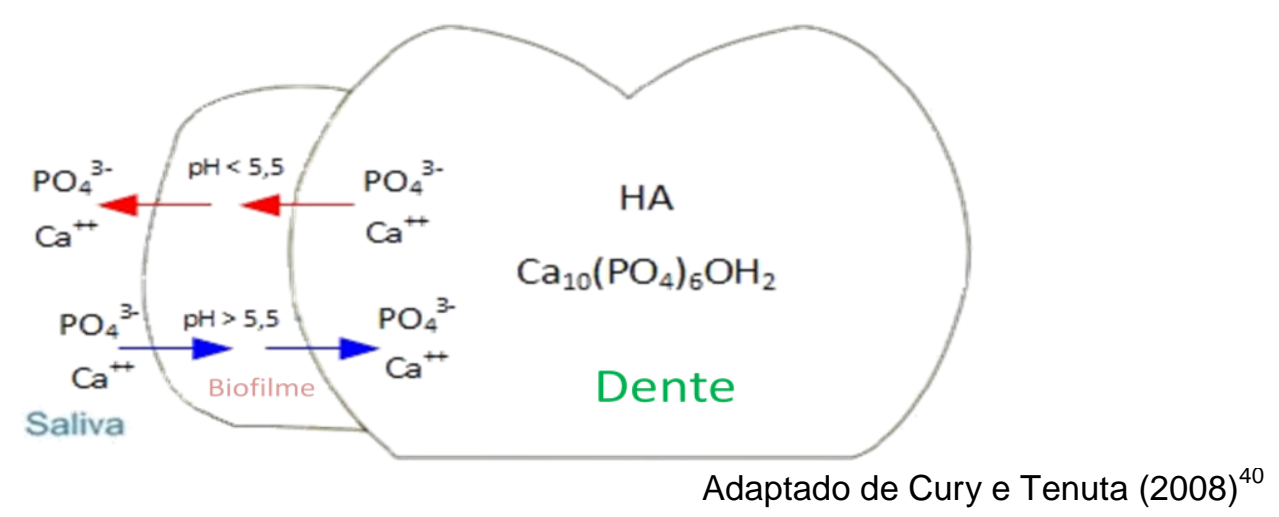

FIGURA 1: Processos de desmineralização e remineralização do esmalte dental na presença de biofilme. Para valores de $\mathrm{pH}$ abaixo de 5,5 ocorre desmineralização e para valores acima deste, há predomínio do processo inverso.

Os ácidos do biofilme são neutralizados por sistemas tampão salivares (bicarbonato/carbonato, proteínas e fosfato), após, aproximadamente, 20 minutos ${ }^{39}$.

Nas situações em que a frequência de consumo de carboidratos fermentáveis é alta, as condições de higiene bucal são inadequadas e/ou há alterações salivares, o processo de desmineralização é predominante sobre a remineralização, iniciando a formação de lesões de cárie ${ }^{40}$. Nessas lesões, o aumento da porosidade do esmalte promovido pela desmineralização inicial facilita a difusão dos ácidos bacterianos e a progressão das lesões. A remineralização insuficiente limita-se à superfície do esmalte, o que possibilita 0 surgimento de uma região subsuperficial, denominada corpo da lesão, que é menos mineralizada que a camada mais externa do esmalte. Essa perda mineral é clinicamente perceptível através da presença de mancha branca, ocasionada pela mudança do índice de refração ${ }^{1}$. A evolução do processo de desmineralização leva à perda de suporte mecânico da superfície remineralizada e, então, ocorre cavitação ${ }^{41}$.

Os modelos de ciclagem de $\mathrm{pH}$, como o desenvolvido por Feathestone et al. (1986) ${ }^{23}$ são bastante utilizados para simular o processo de cárie, por reproduzir os períodos de desmineralização e remineralização que ocorrem no meio bucal ${ }^{17,18,42}$. O emprego dessa metodologia preconiza a imersão das amostras em solução desmineralizante, com pH 4,5 por 6 horas e em solução remineralizante com $\mathrm{pH} 7,0$ por 17 horas $^{23}$. 
Argenta et al. $(2003)^{24}$, em seu estudo sobre ciclagens de pH para avaliar o efeito de fluoretos na desmineralização do esmalte, propuseram modificações na metodologia desenvolvida por Featherstone et al. $(1986)^{23}$, de forma a evitar a erosão da superfície. $O$ tempo de desmineralização foi reduzido para 3 horas e o de remineralização aumentado para 20 horas. Além das alterações de tempo, o modelo preconiza o acréscimo de flúor em ambas as soluções. Dessa maneira, esse método de ciclagem possibilita a obtenção de lesões com camada superficial mineralizada, com maior semelhança às lesões naturais em estágios iniciais.

\subsection{Tomografia por coerência óptica (OCT)}

O sistema de OCT baseia-se no interferômetro de Michelson, sendo empregada uma fonte de luz com grande largura espectral, com comprimento de onda próximo ao infravermelho, por ser essa região do espectro a que sofre menos absorção pelos principais componentes dos tecidos biológicos. São utilizados como fonte de luz, por exemplo, lasers de Titânio-Safira, LEDs Superluminescentes e lasers com varredura em comprimento de onda (swept sources) $)^{43}$. A FIGURA 2 apresenta um diagrama esquemático do sistema de OCT.

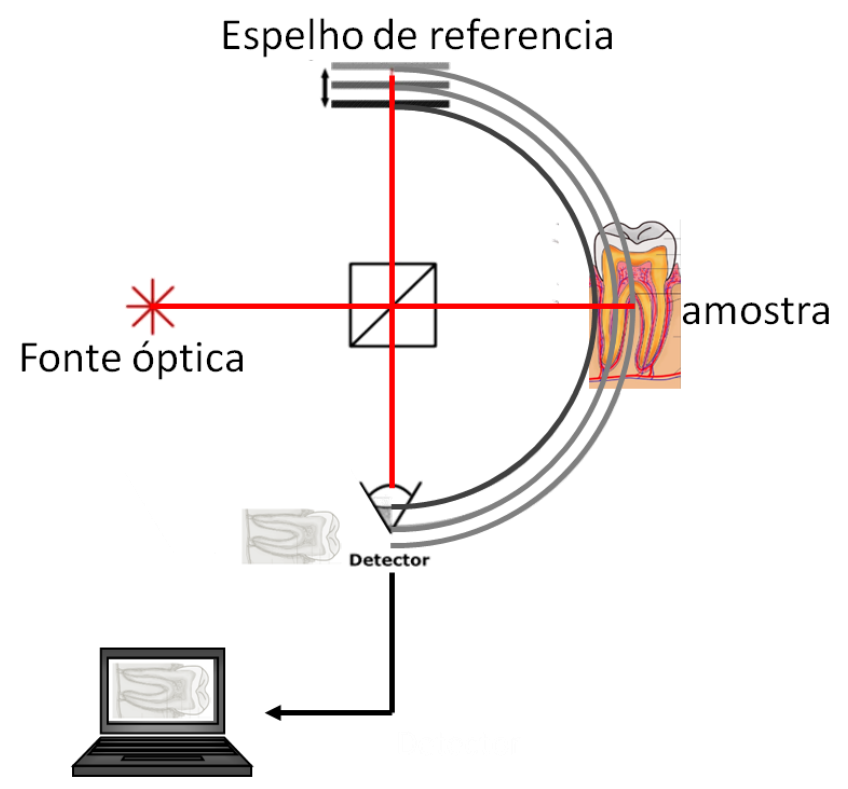

FIGURA 2: Ilustração esquemática de um arranjo OCT. A fonte ilumina os dois braços do interferômetro. A posição do espelho de referência determina a profundidade a ser "observada" na amostra pelo tempo de vôo dos fótons. Junto ao detector, está ilustrada a formação de uma imagem OCT. A linha curva projeta o tamanho do braço de referência sobre o braço da amostra, e relaciona ambos com a imagem formada. 
A luz emitida atravessa um elemento óptico que divide o feixe em duas partes iguais, sendo uma parte direcionada para o espelho do braço de referência do aparelho e outra parte para a amostra. A luz refletida do espelho presente no braço de referência e a luz retroespalhada da amostra são recombinadas no divisor de feixe, ocorrendo interferência entre elas. A intensidade do feixe recombinante é mensurada por um detector óptico, a qual é proporcional ao quadrado do campo elétrico resultante ${ }^{21}$.

Para obtenção de sinais de interferência, o caminho óptico da luz do braço de referência e o caminho óptico do braço da amostra devem ser iguais, ou a diferença entre eles deve menor que o comprimento de coerência da fonte. Desse modo, através da modificação do caminho óptico percorrido pela luz até o espelho do braço de referência é possível obter informações oriundas de diferentes profundidades do objeto em estudo ${ }^{44,45}$. Os sinais de intensidade captados pelo detector são transmitidos a um computador, onde são analisados.

No processo de formação das imagens, cada sinal de OCT corresponde a uma varredura axial da amostra (denominada A-scan) e sua amplitude é proporcional à intensidade da luz retroespalhada em função da profundidade. A translação do feixe de luz em relação à amostra gera uma série destes sinais em função da posição transversal (B-scan) ${ }^{46}$. Dessa forma, um sinal de intensidade de luz retroespalhada é captado para cada posição axial e transversal associadas. A conversão dos valores de intensidade do B-scan em tonalidades numa escala de cores falsas possibilita a obtenção de imagens bidimensionais da amostra ${ }^{47}$ Através da associação de imagens bidimensionais é possível obter a reconstrução da imagem em três dimensões ${ }^{48}$.

A profundidade da amostra avaliada pela OCT varia de 1 a $3 \mathrm{~mm}$ para a maioria dos tecidos biológicos, pois devido à natureza destes tecidos, como coeficiente de espalhamento, coeficiente de absorção e suas dependências com o comprimento de onda, a quantidade de luz retroespalhada é insuficiente para ser detectada em profundidades maiores que as descritas ${ }^{44}$.

A primeira aplicação da técnica de OCT em Odontologia foi descrita em $1998^{48}$, para obtenção de imagens de tecidos moles e duros da cavidade oral, para a detecção de lesões de cárie, fraturas dentais, patologias de tecido mole e doenças periodontais. Vários trabalhos têm aplicado a técnica para diagnóstico de 
lesões de cárie ${ }^{7,8,16,17,19}$ devido às alterações ópticas sofridas pelo esmalte em decorrência da desmineralização ${ }^{49}$. A amplitude do sinal de OCT detectado é maior para o esmalte desmineralizado quando comparado ao esmalte sadio ${ }^{2,46}$.

As imagens obtidas através do sistema de OCT podem ser avaliadas qualitativamente $^{19,47}$ e quantitativamente através da análise de parâmetros da amplitude do sinal, como refletividade integrada ${ }^{17}$ e coeficiente de atenuação óptica total ${ }^{46,21,50}$.

Em seu estudo, Fried et al. (2002) ${ }^{2}$, utilizando uma variação da técnica de OCT sensível à polarização da luz incidente, concluíram ser possível detectar diferença no grau de mineralização do esmalte dental em dentes humanos submetidos a 3 e 14 dias de ciclagens de $\mathrm{pH}$ (seguindo a metodologia proposta por Featherstone et al. em $1986^{23}$ ), através do cálculo da área obtida em gráficos de intensidade do sinal retroespalhado em função da profundidade (refletividade integrada). Utilizando metodologia de análise semelhante à anteriormente descrita, Jones e Fried (2006) demonstraram que a remineralização do esmalte promove diminuição do sinal de retroespalhamento detectado. A técnica de Tomografia por coerência óptica sensível à polarização empregada nesses estudos, caracteriza-se pela utilização de uma fonte de luz linearmente polarizada, com comprimento de onda central de $1310 \mathrm{~nm}$ e o sinal de retroespalhamento é detectado em dois canais ortogonais de polarização ${ }^{9,22}$. Seu emprego permite melhor visualização da camada mais externa do esmalte, uma vez que através da escolha da polarização a reflexão na superfície pode ser controlada ${ }^{2,9,21}$. Além disso, seu emprego possibilita verificar alterações na birrefringência do esmalte sadio, devido à organização prismática deste ${ }^{51}$.

Popescu et al.(2008) ${ }^{46}$ e Sowa et al.(2011) ${ }^{52}$ observaram menor atenuação do sinal de OCT para esmalte dental desmineralizado quando comparado ao esmalte sadio, através da análise quantitativa do coeficiente de atenuação óptica total, calculado a partir do decaimento exponencial da intensidade da luz detectada (retroespalhada). 


\subsection{Microdureza seccional}

A microdureza seccional é uma técnica de análise quantitativa amplamente empregada para avaliação de perda mineral do esmalte dental em profundidade. Por ser um método diagnóstico destrutivo, não tem aplicações clínicas ${ }^{26}$.

Os ensaios de microdureza podem ser do tipo Vickers ou Knoop, de acordo com o formato da ponta indentadora. Devido à proximidade das indentações, nos trabalhos da área odontológica a microdureza Knoop é mais utilizada. Nesse tipo de teste, o valor de dureza é calculado com base na medida do comprimento da maior largura da indentação ${ }^{24,25,26}$ (FIGURA 3).

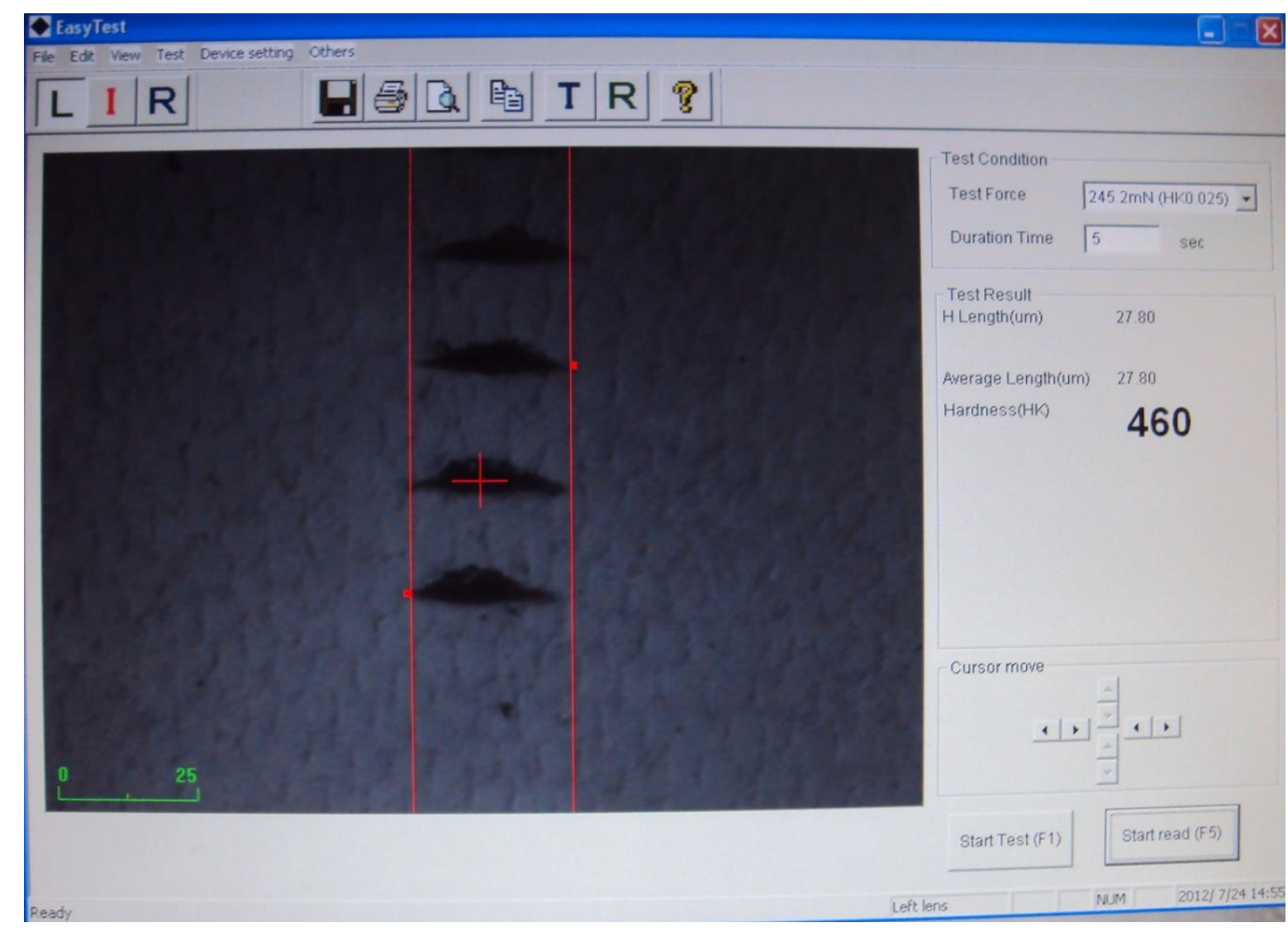

FIGURA 3: Interface do programa associado ao microdurômetro para obtenção dos valores de dureza Knoop. As linhas (em vermelho) são posicionadas nas extremidades da indentação e, então, o valor de dureza é fornecido automaticamente (no exemplo, o valor é $460 \mathrm{Kgf.} \mathrm{mm}^{-2}$ ).

Os valores de microdureza estão relacionados com a quantidade de minerais na região do esmalte dental analisada. Featherstone et al. (1983) ${ }^{53}$ Kielbassa et al.(1999) ${ }^{26}$ demonstraram a existência de elevada correlação entre 
as técnicas de microdureza e microrradiografia, a qual foi considerada padrão de referência para avaliação de perda mineral. 


\section{MATERIAIS E MÉTODOS}

Para o estudo foram utilizados 53 dentes terceiros molares doados pelo Banco de dentes da Faculdade de Odontologia da Universidade de São Paulo (APÊNDICE A), sob aprovação do comitê de Ética em Pesquisa da mesma Faculdade (número do projeto aprovado: FR360665 - protocolo153/2010 APÊNDICE B).

O estudo foi dividido em 2 etapas: um estudo piloto, onde foram utilizados 13 dentes e o experimento final, realizado com os 40 dentes restantes.

\subsection{Delineamento experimental}

Para o estudo piloto, as amostras foram divididas em sete grupos com 7 amostras cada, assim classificados:

- Grupo 0 (grupo controle) - amostras hígidas, não submetidas a tratamento;

- Grupo 1 -amostras submetidas a 5 dias de ciclagem de pH;

- Grupo 2 - amostras submetidas a 10 dias de ciclagem de pH;

- Grupo 3 -amostras submetidas a 15 dias de ciclagem de pH;

- Grupo 4-amostras submetidas a 20 dias de ciclagem de pH;

- Grupo 5-amostras submetidas a 25 dias de ciclagem de pH;

- Grupo 6 - amostras submetidas a 30 dias de ciclagem de $\mathrm{pH}$.

Após avaliação dos resultados obtidos no experimento piloto de variação de conteúdo mineral verificada pela microdureza, considerando o desvio padrão da média apresentado por cada grupo, foram estabelecidos, para o experimento final, 4 grupos com 40 amostras cada, assim classificados:

- Grupo 0 (grupo controle) - amostras hígidas, não submetidas a tratamento;

- Grupo 1 - amostras submetidas a 7 dias de ciclagem de pH;

- Grupo 2 - amostras submetidas a 14 dias de ciclagem de pH;

- Grupo 3 - amostras submetidas a 21 dias de ciclagem de pH.

As amostras de ambos os experimentos foram examinadas pela técnica de OCT no início dos experimentos, submetidas a ciclos de desmineralização e remineralização e novamente examinadas por OCT. Após o exame, as amostras foram seccionadas, embutidas e submetidas a testes de 
microdureza seccional. O delineamento experimental é apresentado na FIGURA 4.

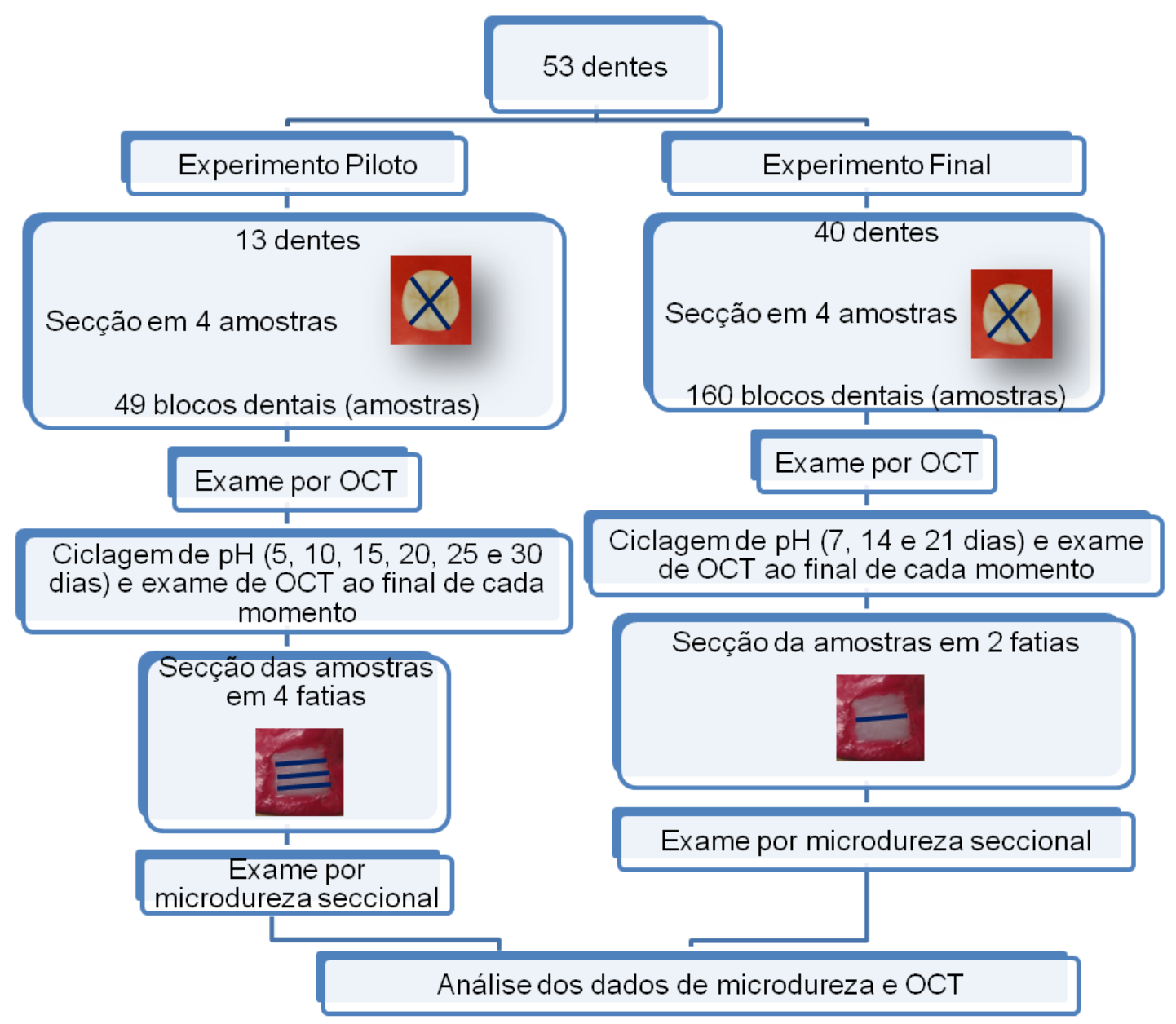

FIGURA 4: Esquema do delineamento experimental.

A alocação das amostras nos grupos foi aleatória para ambos os experimentos.

\subsection{Preparação das amostras}

Os dentes foram fixados em placas acrílicas com cera pegajosa (kota, SP, Brasil) e cortados, com o auxílio de uma cortadeira (Accuton 5-Struers, UK) de forma a remover as raízes dentais e posteriormente seccionar as coroas em 4 partes, seguindo planos de corte apresentados na FIGURA 5. Dessa maneira, foi possível obter 212 blocos, os quais foram limpos e avaliados para assegurar a ausência de sinais de desmineralização do esmalte (ausência de mancha 
branca). A limpeza foi realizada utilizando um aparelho de ultrassom (Cristófoli, PR, Brasil) e escovação com escova de Robinson (KG Sorensen, SP, Brasil) usando micromotor de baixa-rotação (Dabi Atlante, SP, Brasil), com pedra-pomes (SS-White, SP, Brasil) e água. A seguir, as amostras foram secas com lenço de papel e posteriormente com jatos de ar, para então serem avaliadas clinicamente, com o auxílio de lupa estereoscópica com aumento de 10 vezes (Nikon Instrument group). Foram selecionadas 49 amostras para o experimento piloto e 160 amostras para o experimento final.

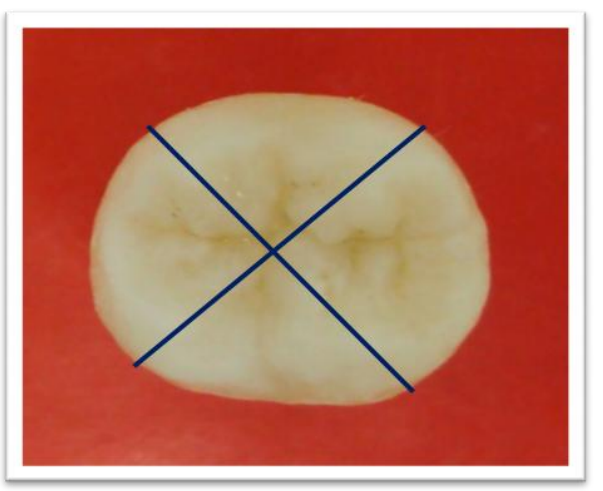

FIGURA 5: Esquema de corte da coroa dental para obtenção das amostras. Os planos de secção estão indicados pelas linhas azuis.

Para padronização das amostras, cada bloco teve delimitada uma área de $6,25 \mathrm{~mm}^{2}$, onde foram induzidas lesões simuladas de cárie e foram realizados exames de OCT e microdureza seccional. A delimitação da referida área foi obtida através da colagem de etiquetas (Pimaco - Bic, RJ, Brasil) quadradas, com 2,5 $\mathrm{mm}$ de lado, sobre o esmalte dental, as quais foram removidas após recobrimento do remanescente das amostras por um verniz ácido resistente (esmalte de unha Revlon, NY, USA).

As amostras foram fixadas com cera de uso odontológico (Cera Utilidade - Epoxiglass, SP, Brasil) em placas de resina acrílica polimerizante (Classico-Jet SP, Brasil), conforme apresentado na FIGURA 6, para facilitar armazenagem e posicionamento das mesmas durante os exames de OCT. 


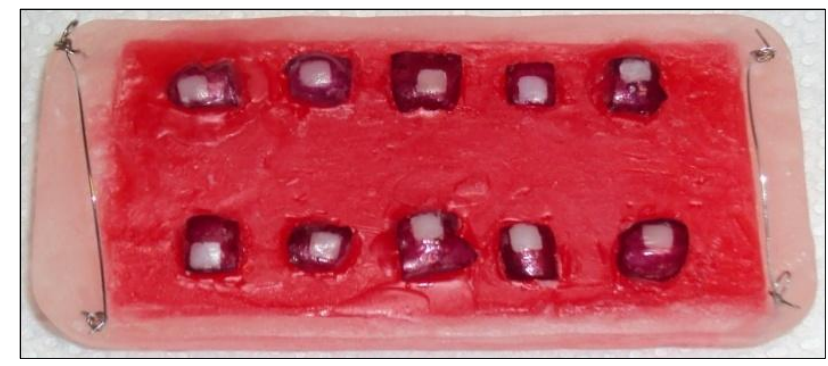

FIGURA 6: Posicionamento das amostras nas placas utilizadas para o exame de OCT.

Durante o tempo em que não estavam sendo processadas, as amostras foram acondicionadas em meio úmido e sob refrigeração (cerca de $5^{\circ} \mathrm{C}$ ) para evitar a proliferação de microorganismos (Figura 7).

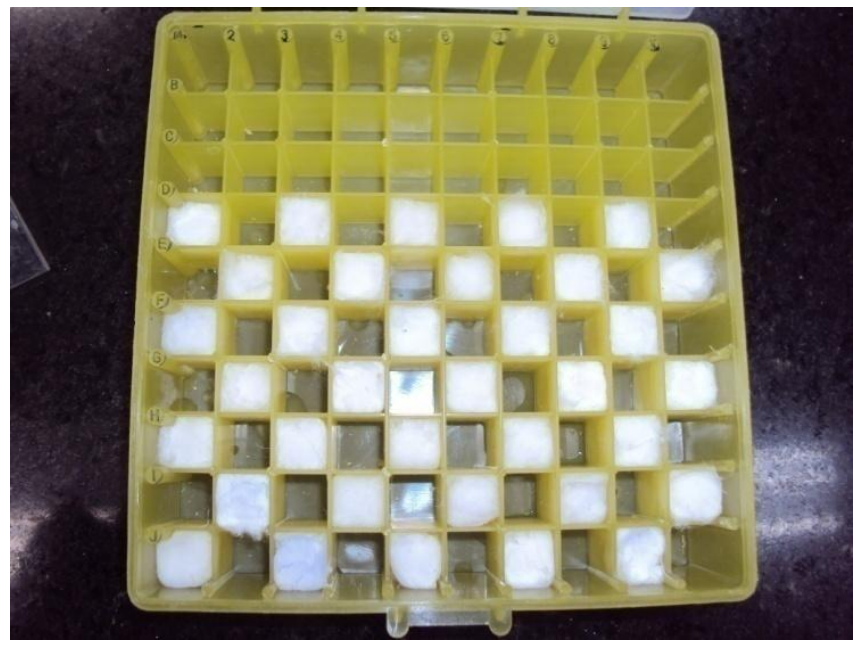

FIGURA 7: Fotografia de caixa para armazenamento refrigerado, com amostras cobertas por algodão umedecido em água Milli-Q.

\subsection{Simulação do desafio cariogênico in vitro}

Para simular lesões de cárie de diferentes graus de desmineralização, foi adotado o método de ciclagem de $\mathrm{pH}$ de acordo com a modificação proposta por Argenta et al.(2003) ${ }^{24}$ da metodologia desenvolvida por Feathestone et al.(1986) $)^{23}$. As amostras ficaram diariamente imersas em solução desmineralizante por 3 horas e remineralizante durante 20 horas, mantidas a temperatura de $37^{\circ} \mathrm{C}$, sendo 1 hora reservada à preparação das amostras para troca de soluções durante a ciclagem (lavagem das amostras com água Milli-Q e secagem com lenço de papel). A solução desmineralizante foi composta por 2,0 mmol L $\mathrm{L}^{-1}$ de cálcio, $2,0 \mathrm{mmol} \mathrm{L}^{-1}$ de fosfato, 0,03 ppm de flúor e solução tampão 
de acetato $0,075 \mathrm{~mol} \mathrm{~L}^{-1}$, com pH 4,3, enquanto a solução remineralizante foi composta por $1,5 \mathrm{mmol} \mathrm{L}^{-1}$ de cálcio, $0,9 \mathrm{mmol} \mathrm{L}^{-1}$ de fosfato, $150 \mathrm{mmol} \mathrm{L}^{-1}$ de cloreto de potássio, $0,05 \mathrm{ppm}$ de flúor e $20 \mathrm{mmol} \mathrm{L}^{-1}$ de tampão cacodilato em pH 7,4 .

Para preparo de $1 \mathrm{~L}$ das soluções desmineralizante e remineralizante, os reagentes foram adicionados a aproximadamente $900 \mathrm{~mL}$ de água destilada e bideionizada. $\mathrm{O}$ pH das soluções foi ajustado através do uso do pHmetro (Orion DualStar - ThermoScientific) e então, foi acrescida quantidade de água suficiente, para completar $1 \mathrm{~L}$ de cada solução. Foram empregadas, na sequência abaixo descrita, as seguintes quantidades de reagentes:

- Solução desmineralizante

- 0,4723 g Nitrato de Cálcio tetrahidratado $\left[\mathrm{Ca}\left(\mathrm{NO}_{3}\right)_{2} \cdot 4 \mathrm{H}_{2} \mathrm{O}\right]$ - Merck S.A, São Paulo, Brasil;

- 0,3558 g Fosfato de Sódio diidratado $\left[\mathrm{Na}_{2}\left(\mathrm{PO}_{4}\right) \cdot 2 \mathrm{H}_{2} \mathrm{O}\right]$ - Merck S.A, São Paulo, Brasil;

- 0,3 mL padrão de flúor de 100 ppm - ThermoOrion Inc., MA, USA;

- 4,28927 mL solução ácido acético glacial $\left[\mathrm{CH}_{3} \mathrm{COOH}\right]$ - Merck S.A, São Paulo, Brasil.

- Solução Remineralizante

- 0,35422 g Nitrato de Cálcio tetra-hidratado $\left[\mathrm{Ca}\left(\mathrm{NO}_{3}\right)_{2} \cdot 4 \mathrm{H}_{2} \mathrm{O}\right]$ - Merck S.A, São Paulo, Brasil;

- $\quad$,16017 g Fosfato de Sódio diidratado $\left[\mathrm{Na}_{2}\left(\mathrm{PO}_{4}\right) \cdot 2 \mathrm{H}_{2} \mathrm{O}\right]$ - Merck S.A, São Paulo, Brasil;

- 11,1825 g Cloreto de Potássio [KCl] - Merck S.A, São Paulo, Brasil;

- $0,5 \mathrm{~mL}$ solução padrão de flúor de 100 ppm - ThermoOrion Inc., MA, USA;

- 4,4134 g Ácido dimetilarsínico $\left[\left(\mathrm{CH}_{3}\right)_{2} \mathrm{As}(=\mathrm{O}) \mathrm{ONa}\right]$ - Merck S.A, São Paulo, Brasil.

Seguindo o método, foram necessários $40 \mathrm{~mL}$ de solução desmineralizante e $20 \mathrm{~mL}$ de solução remineralizante por amostra, para cada intervalo de 5 dias de ciclagem (TABELA 1). 
TABELA 1 - Soluções utilizadas de desmineralização e remineralização

\begin{tabular}{l|l|}
\hline $\begin{array}{l}\text { Volume por } \\
\text { amostra }\end{array}$ & $40 \mathrm{~mL}$ \\
\hline Composição & $\begin{array}{l}2,0 \mathrm{mM} \text { de cálcio, } \\
2,0 \mathrm{mM} \text { de fosfato, } \\
0,03 \mathrm{ppm} \text { de flúor e } \\
\text { solução tampão de } \\
\text { acetato } 0,075 \mathrm{M}, \\
\text { com pH 4,3 }\end{array}$ \\
\hline tempo & 3 horas \\
\hline
\end{tabular}

\begin{tabular}{|l|l|}
\hline $\begin{array}{l}\text { Volume por } \\
\text { amostra }\end{array}$ & $20 \mathrm{~mL}$ \\
\hline Composição & $\begin{array}{l}1,5 \mathrm{mM} \text { de cálcio, } \\
0,9 \mathrm{mM} \text { de fosfato, } \\
150 \mathrm{mM} \text { de cloreto } \\
\text { de potássio, } 0,05 \\
\text { ppm de flúor e } 20 \\
\mathrm{mM} \text { de tampão } \\
\text { cacodilato em pH7,4 }\end{array}$ \\
tempo & 20 horas \\
\hline
\end{tabular}

Assim, para o estudo piloto, considerando o tempo de ciclagem de cada grupo, foi necessário preparar aproximadamente $6 \mathrm{~L}$ de solução desmineralizante e $3 \mathrm{~L}$ de solução remineralizante. Para o experimento final foram necessários aproximadamente $16 \mathrm{~L}$ de solução desmineralizante e $8 \mathrm{~L}$ de solução remineralizante. Devido ao elevado volume de soluções empregadas no experimento final, essas foram preparadas em pequenas quantidades e então acondicionadas em recipientes plásticos de $20 \mathrm{~L}$ de volume, para que houvesse homogeneização das soluções.

As amostras foram cicladas individualmente, para que não houvesse troca de minerais entre elas. Para cada amostra, foram utilizados 2 tubos Falcon de $50 \mathrm{~mL}$ a cada 5 dias, quando as soluções eram trocadas para evitar saturação das mesmas. Assim foram utilizados 294 tubos para o estudo piloto e 800 tubos para o experimento final, os quais foram acondicionados em suportes acrílicos, conforme apresentado na FIGURA 8. 


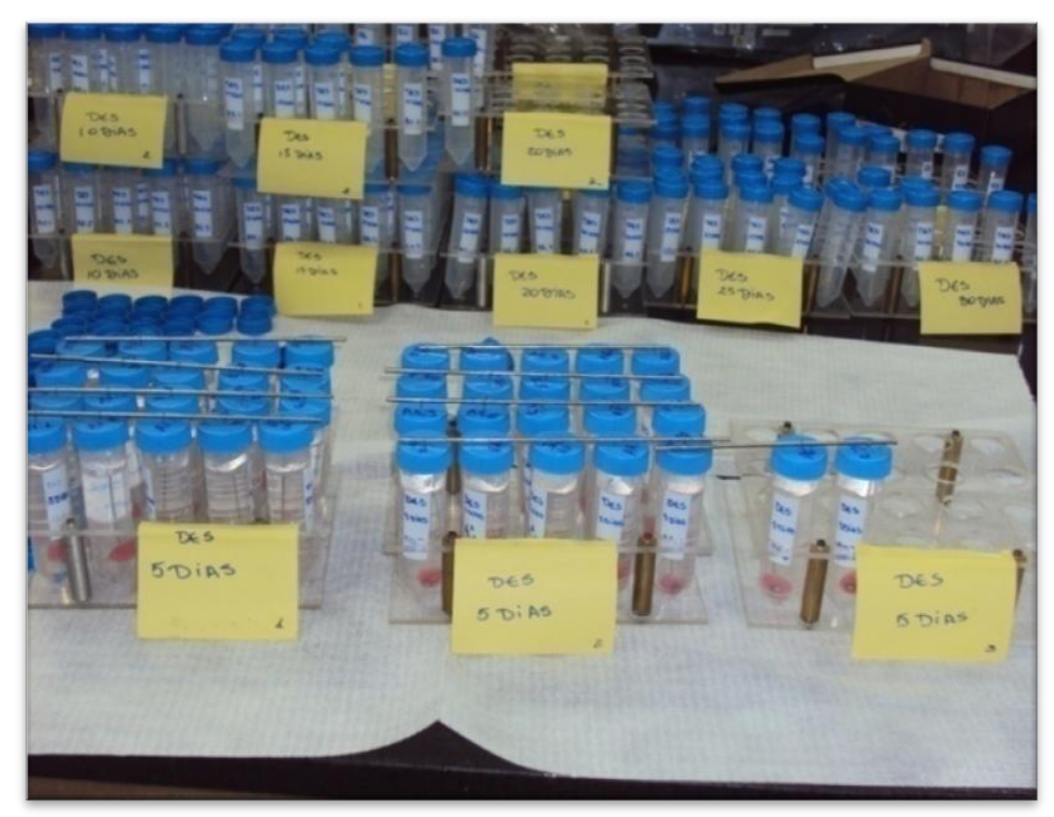

FIGURA 8: Tubos acondicionados em suportes acrílicos para ciclagem de $\mathrm{pH}$.

Para realizar a ciclagem de $\mathrm{pH}$, as amostras foram fixadas com auxílio de cera de uso odontológico (Cera 7 - Epoxiglass, SP, Brasil) a fios ortodônticos de aço inoxidável (Morelli, SP, Brasil), unidos às tampas dos tubos Falcon. O conjunto descrito foi fixado a hastes confeccionadas em aço inoxidável, para permitir que as amostras fossem trocadas de solução simultaneamente (FIGURA 9).

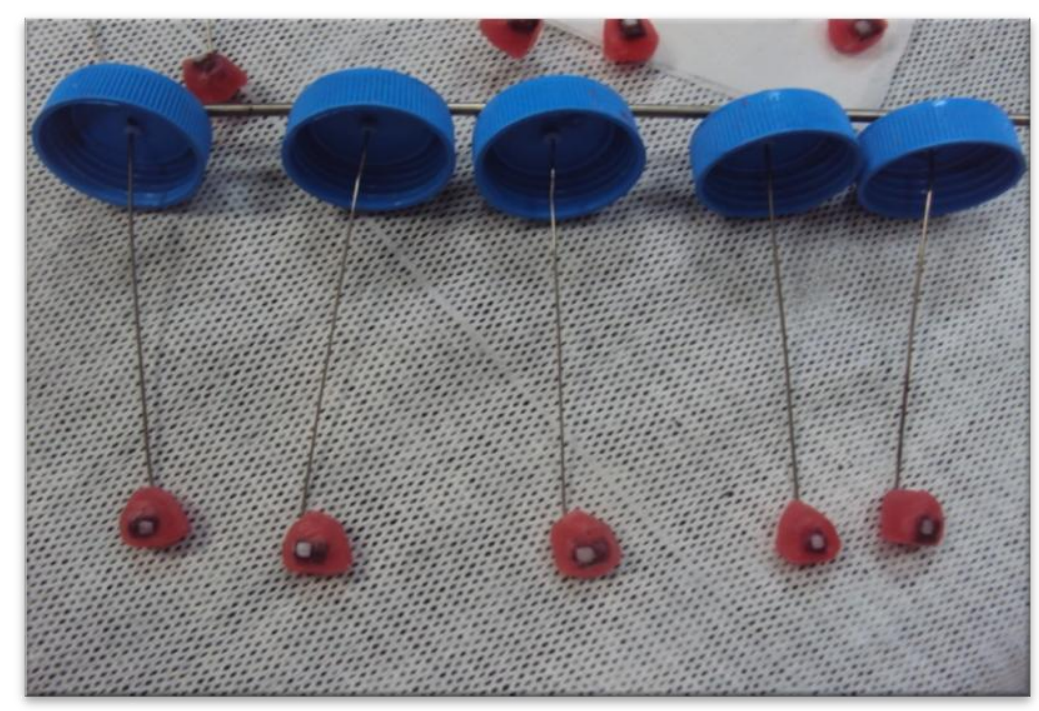

FIGURA 9: Suporte das amostras para ciclagem de $\mathrm{pH}$. Os fios ortodônticos contendo as amostra fixadas nas extremidades, presos a haste metálica por alças confeccionadas nos fios. 
Durante o período de ciclagem, as amostras foram mantidas a $37^{\circ} \mathrm{C}$ em estufa (Marconi.S.A, SP, Brasil). Para evitar a influência de pequenas variações de temperatura que podem ocorrer nas diferentes partes da estufa, foi realizado o rodízio das estantes acrílicas contendo os tubos Falcon ao final de cada ciclo de 24 horas. Para as trocas de soluções, as amostras foram retiradas da estufa e lavadas sempre na mesma sequência, de modo a uniformizar o tempo de imersão de cada amostra nas soluções. Cada amostra foi enxaguada com água destilada e bideionizada durante 10 segundos.

\subsection{Exame das amostras através do emprego da Tomografia por Coerência Óptica (OCT)}

Todas as amostras do estudo piloto e do experimento final foram examinadas através da técnica de OCT no instante inicial do experimento, e exceto aquelas pertencentes aos grupos controle, novamente submetidas ao exame após o término da ciclagem determinado para cada um deles, de forma a possibilitar a comparação intragrupo. As amostras foram umedecidas com água Milli-Q para evitar o ressecamento durante o seu posicionamento e secas com lenço de papel imediatamente antes do exame. Para essa análise foi utilizado um sistema de OCT (FIGURA 10) que emprega uma fonte luminosa com comprimento central de onda de $930 \mathrm{~nm}$, com $2 \mathrm{~mW}$ de potência (OCP930RS Thorlabs Inc., disponível no laboratório de Tomografia Óptica do Centro de Lasers e Aplicações - IPEN-CNEN/SP).

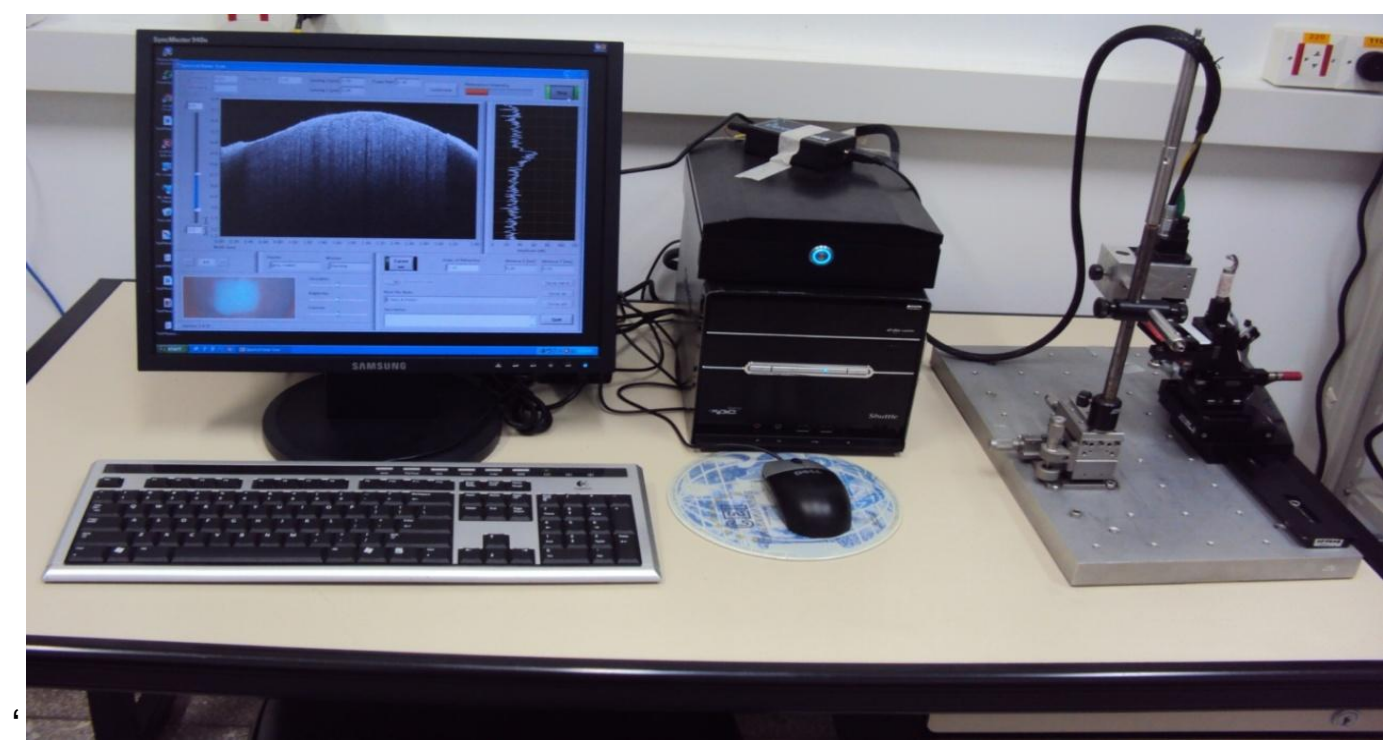

FIGURA 10: Fotografia do equipamento de OCT para exame das amostras. 
Nos exames de OCT, foram obtidas imagens de toda extensão da área, a qual foi inicialmente delimitada durante a preparação das amostras. A resolução axial foi de 4,0 $\mu \mathrm{m}$ (considerando o índice de refração do esmalte de aproximadamente $1,6^{50}$ ) visto que o equipamento tem uma resolução nominal de $6,0 \mu \mathrm{m}$ no ar e resolução lateral de $6,0 \mu \mathrm{m}$.

As imagens das porções centrais das áreas delimitadas foram avaliadas, conforme apresentado na FIGURA 11 utilizando um programa desenvolvido pelo grupo do laboratório de OCT em ambiente de programação LabView 8.

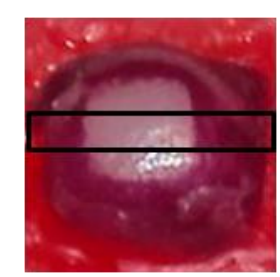

FIGURA 11: Região central utilizada para análise dos dados de OCT.

Para o cálculo do coeficiente de atenuação óptica, foi utilizado um modelo simples de decaimento exponencial da intensidade da luz detectada (retroespalhada), de acordo com a equação:

$$
I(z)=I_{0} \cdot e^{-2 \alpha \cdot z}+C
$$

onde, I representa o valor da intensidade detectada, $I_{0}$ é o valor da intensidade da fonte luminosa, $\alpha$ é o coeficiente de atenuação óptica total, $z$ é a profundidade analisada e $\mathrm{C}$ é uma constante utilizada em decorrência do ruído de fundo do sinal.

O programa desenvolvido permite selecionar uma região de interesse (ROI - Region Of Interest) com o uso dos delimitadores (linhas branca e vermelha) na parte superior da FIGURA 12, sendo que a região selecionada aparece em destaque no canto inferior. Esta delimitação é importante a fim de excluir as bordas devido às irregularidades provocadas pela aplicação do verniz ácido resistente e para a região analisada pela OCT ser a mais próxima possível da região analisada pelo teste de microdureza. As linhas delimitadoras branca e vermelha na região inferior da FIGURA 12, permitem escolher a que profundidade 
da amostra será realizada a análise. No caso desta figura, apenas como exemplo, foi selecionado de 56 a $302 \mu \mathrm{m}$ de profundidade para a análise.

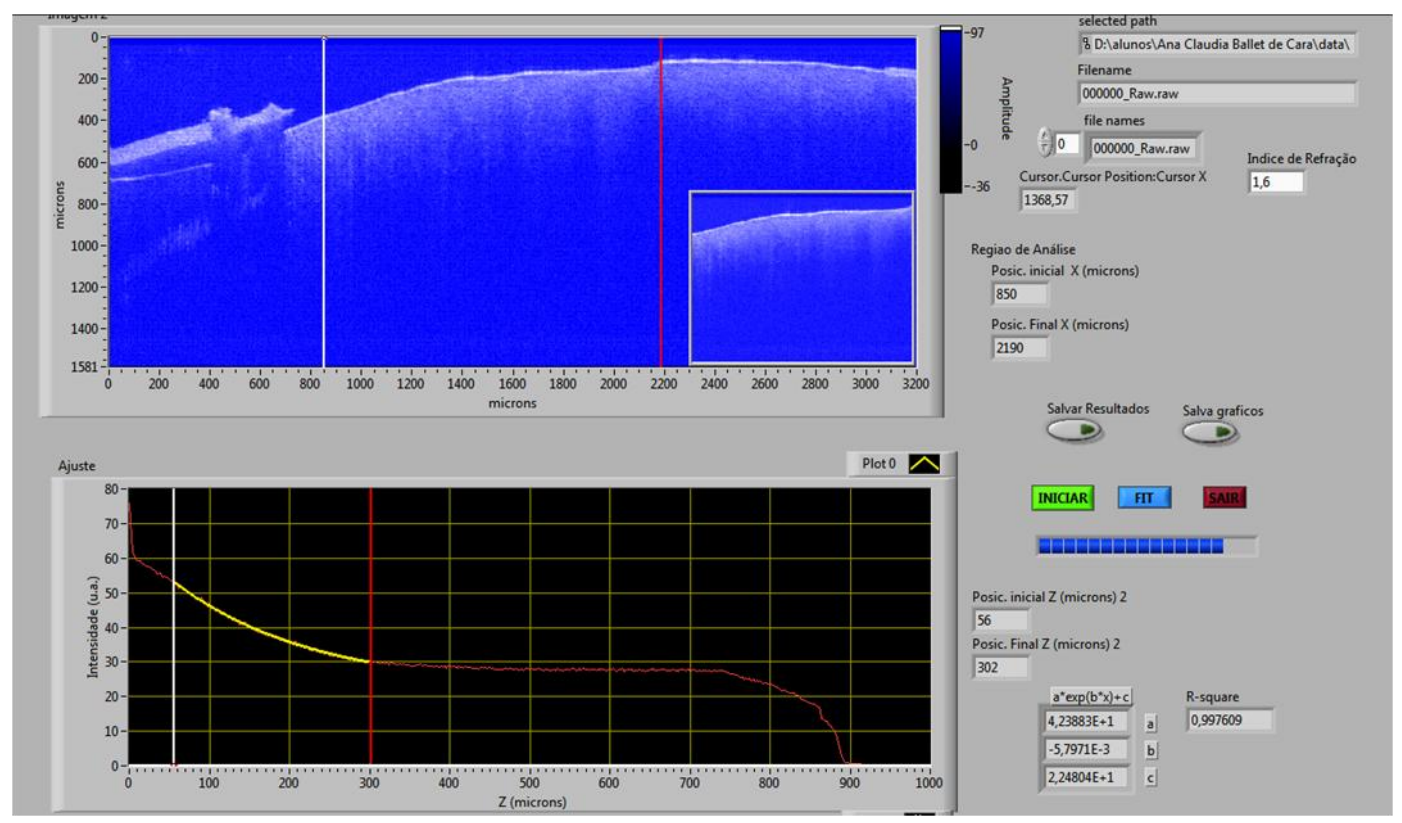

FIGURA 12: Interface do programa utilizado para análise das imagens.

O perfil de decaimento utilizado para a análise, curva apresentada na parte inferior da FIGURA 12, é obtida pela média aritmética de todas as colunas da imagem de OCT na ROI (entre as linhas banca e vermelha na parte superior da FIGURA 12). Para contornar o problema da curvatura das amostras é executada uma detecção de bordas da imagem, para "alinhamento" dos dados entre as linhas delimitadoras. O programa leva também em consideração a resposta do sistema de OCT em função da profundidade (linha base), previamente determinada e a escala em decibéis (dB) $\left(10 . \log \left(1 / / l_{0}\right)\right)$. Uma vez definida a ROI e escolhido o índice de refração para as amostras, o programa executa automaticamente a análise de todas as imagens de todas as amostras de todos os grupos, através do ajuste da função de decaimento exponencial apresentada acima, em destaque amarelo na figura acima. A saída do programa é um arquivo com o nome da amostra analisada, o nome das imagens e seus respectivos parâmetros de ajuste, a, b, e c $\left(I_{0}, \alpha\right.$ e $C$ na equação acima, respectivamente).

Para o experimento final, foi utilizada uma versão atualizada do programa de análise das imagens, na qual foi possível ajustar o índice de refração 
do material analisado. Assim, no estudo piloto, o índice de refração utilizado foi 1, enquanto no experimento sequente foi utilizado índice de refração de 1,6 para o esmalte dental. No estudo piloto, as profundidades selecionadas para análise foram aquelas em que o decaimento da intensidade do sinal de OCT se mostrava mais uniforme. Assim, para cada amostra foi selecionada uma profundidade de análise, que na maioria dos casos estava compreendida entre 40 e $700 \mu \mathrm{m}$. No experimento final, as amostras foram analisadas em várias profundidades, com intervalos compreendidos entre 25 e $700 \mu \mathrm{m}$, para verificar a melhor profundidade de análise do sinal de OCT. Para todas as amostras (experimentos piloto e final) foram avaliadas as regiões centrais de $0,5 \mathrm{~mm}$ por $1,5 \mathrm{~mm}$.

O coeficiente de atenuação óptica de cada amostra foi obtido a partir da média aritmética dos valores de coeficiente de atenuação provenientes de cada uma das imagens analisadas.

As amostras foram novamente examinadas por OCT, mantendo-se os mesmos parâmetros adotados para cada uma das amostras nos exames anteriores. Para que fossem examinadas as mesmas regiões, as amostras foram reposicionadas nos suportes confeccionados em resina acrílica e cera utilidade.

Os valores médios obtidos antes e depois da ciclagem foram analisados, usando teste-t para amostras pareadas, a fim de verificar as alterações sofridas por cada amostra em decorrência da desmineralização. As diferenças entre os coeficientes de atenuação antes e depois da ciclagem de pH dos grupos, também foram comparadas para avaliar se são detectáveis variações destas medidas para os diferentes tempos testados no experimento.

Para o experimento final, além do coeficiente de atenuação óptica total, também foram utilizadas áreas obtidas a partir de gráficos de intensidade de sinal de OCT por profundidade como forma de avaliação de alterações do conteúdo mineral do esmalte dental.

\subsection{Avaliação das amostras por teste de microdureza seccional}

Após a realização dos exames de OCT, ao final da ciclagem de $\mathrm{pH}$, foram realizados os testes de microdureza seccional. Os blocos dentais foram 
fixados em placa acrílica com cera pegajosa em bastão (Kerr Corporation, CA, USA), como apresentado na FIGURA 13.

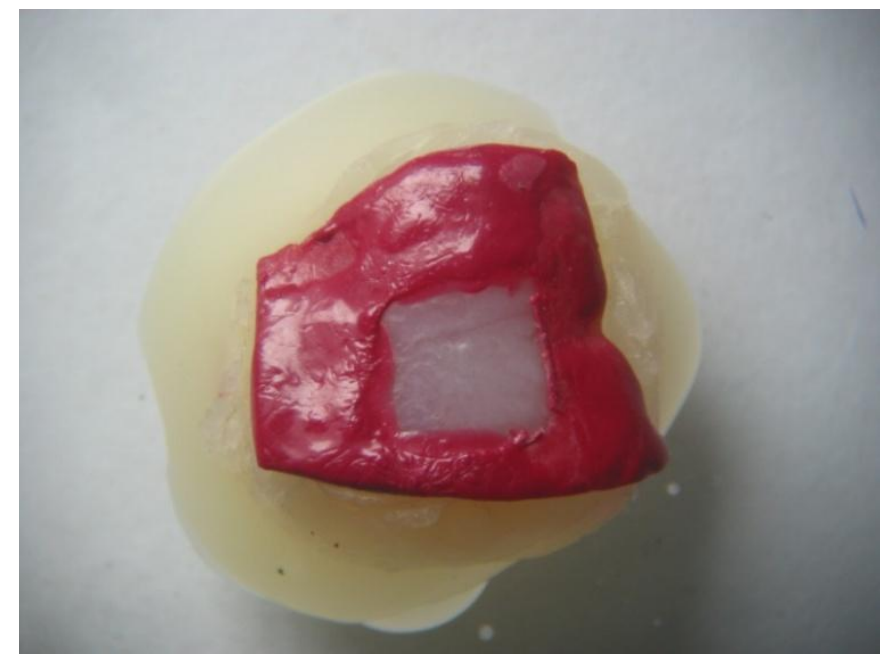

FIGURA 13: Amostra fixada com cera pegajosa à placa acrílica para secção.

Os 49 blocos dentais do experimento piloto foram seccionados, através do uso de cortadeira elétrica (Isomet - Buehler,IL, USA, presente no Laboratório de Amostras do Centro de Lasers e Aplicações - IPEN-CNEN/SP), para obtenção de 4 fatias de cada amostra (FIGURA 14). A secção em fatias foi realizada para verificar se houve variação significativa entre diferentes regiões do esmalte dental quanto ao conteúdo mineral. Metodologia de corte similar foi realizada para o experimento final, porém, foram obtidas apenas 2 fatias de cada amostra.

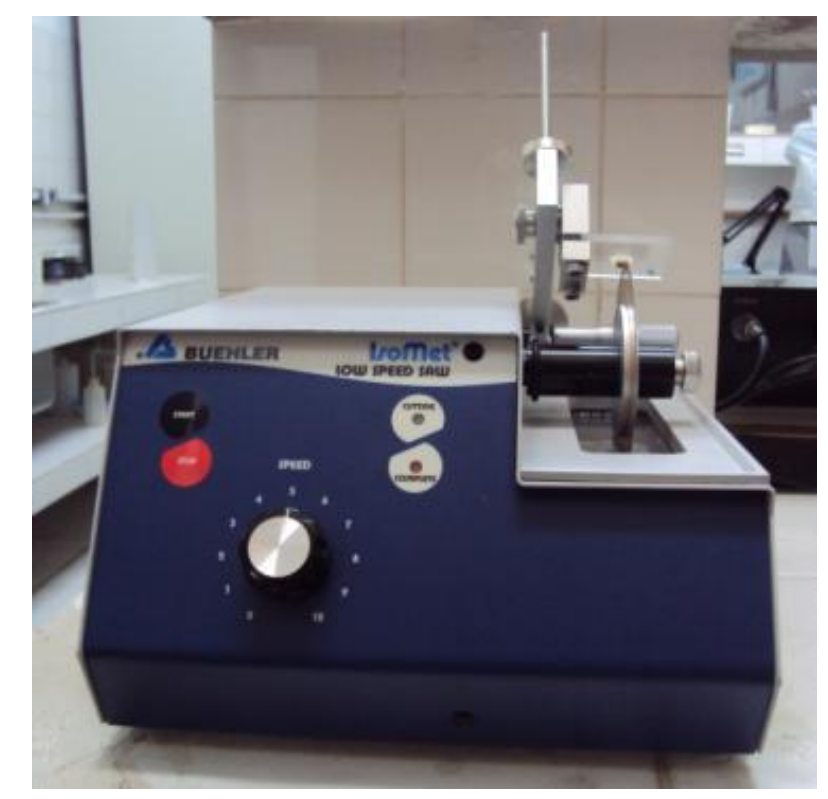

FIGURA 14: Imagem do equipamento utilizado para secção das amostras em fatias. 
As fatias foram embutidas em resina acrílica incolor termicamente ativada (Vip Cril, SP, Brasil) utilizando uma embutidora metalográfica (PRE 30 Arotec S.A. Ind. Com., SP, Brasil). Os corpos de prova obtidos foram polidos, com o auxílio da politriz (AutoMet 250 - Buehler, IL,USA). Esses equipamentos estão apresentados na FIGURA 15.
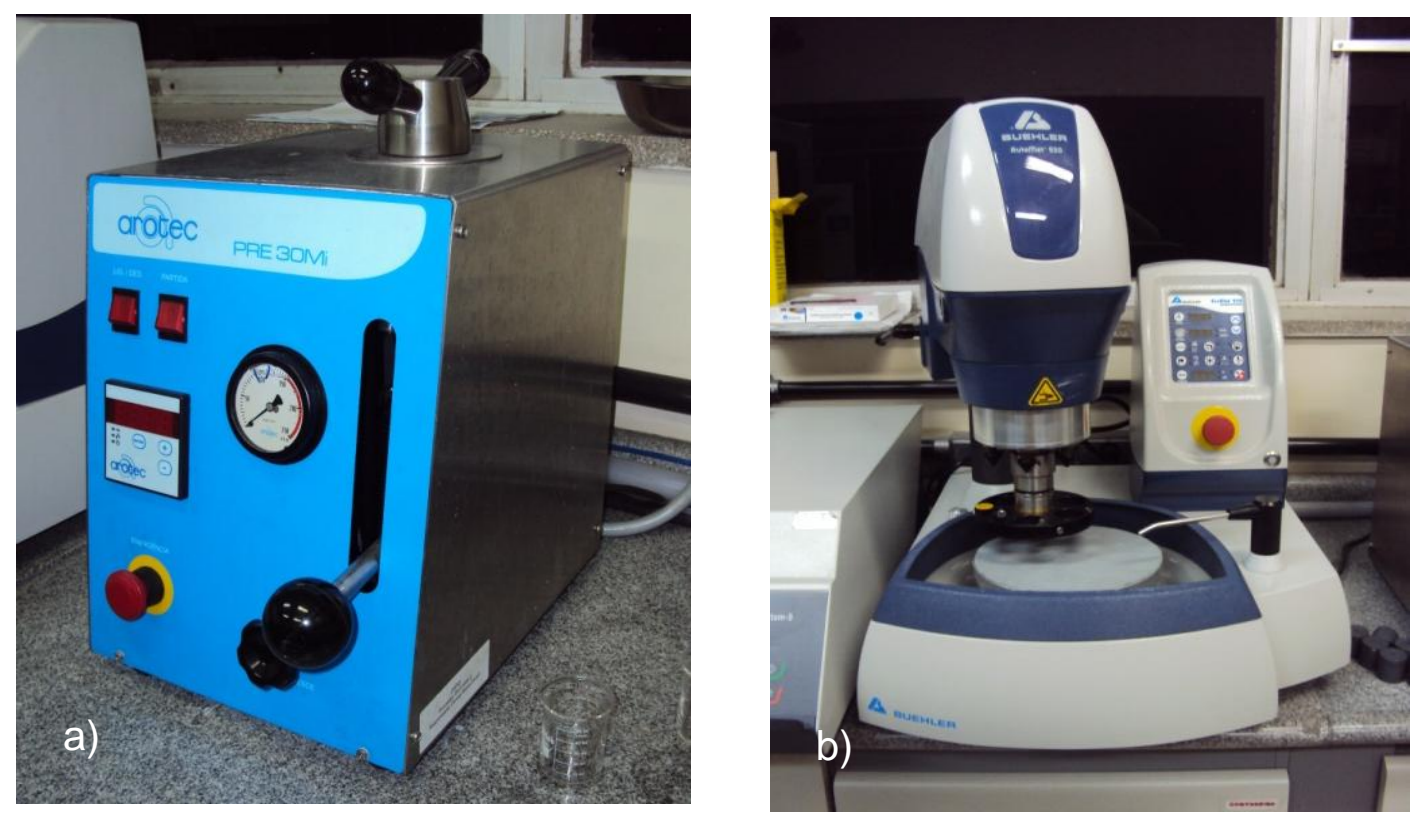

FIGURA 15: Equipamentos utilizados para embutir (a) e polir amostras (b) para exame de microdureza seccional.

No processo de polimento foram empregadas 3 lixas, de granulação 1200, 2500 e 4000 (Carbimed Paper Discs - Buehler, IL, USA), aplicadas nessa ordem e, subsequentemente, disco de feltro (Polishing Cloth METADI - Buehler) umedecido com solução para polimento de granulação de $1 \mu \mathrm{m}$ (METADI Diamond Suspension - Buehler), para aquisição de amostras sem riscos na superfície (condição necessária para análise por microdureza). As amostras foram polidas sob força de $5 \mathrm{~N}$, durante 3 minutos, para o polimento com as lixas de granulação 1200 e 2500 , durante 4 minutos para a lixa de granulação 4000 e durante 5 minutos para o disco de feltro.

A FIGURA 16 apresenta as posições dos cortes realizados para obtenção das fatias e estas preparadas para análise por microdureza seccional no estudo piloto. 

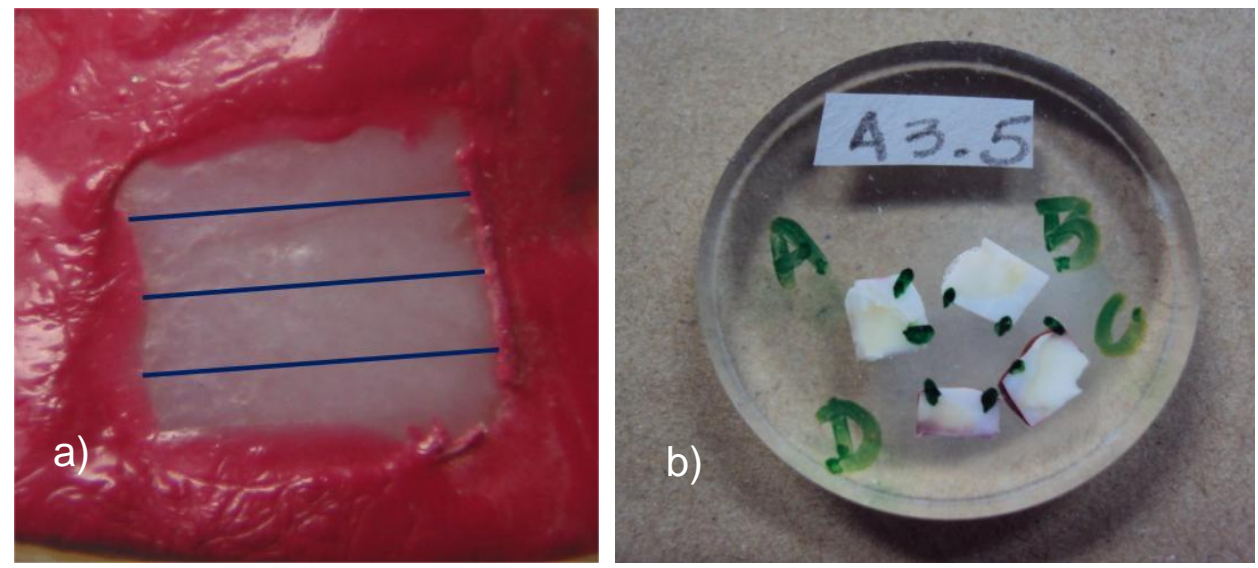

FIGURA 16 - Preparo das amostras para teste de microdureza. a) Planos de secção empregados para obtenção de fatias a serem analisadas por microdureza. b) Amostra preparada para avaliação por microdureza seccional.

As amostras foram submetidas à microdureza seccional, utilizando um microdurômetro acoplado com sistema de análise (HMV 2T, Shimadzu, disponível no laboratório de Biofotônica do Centro de Lasers e Aplicações - IPENCNEN/SP), conforme apresentado na FIGURA 17.

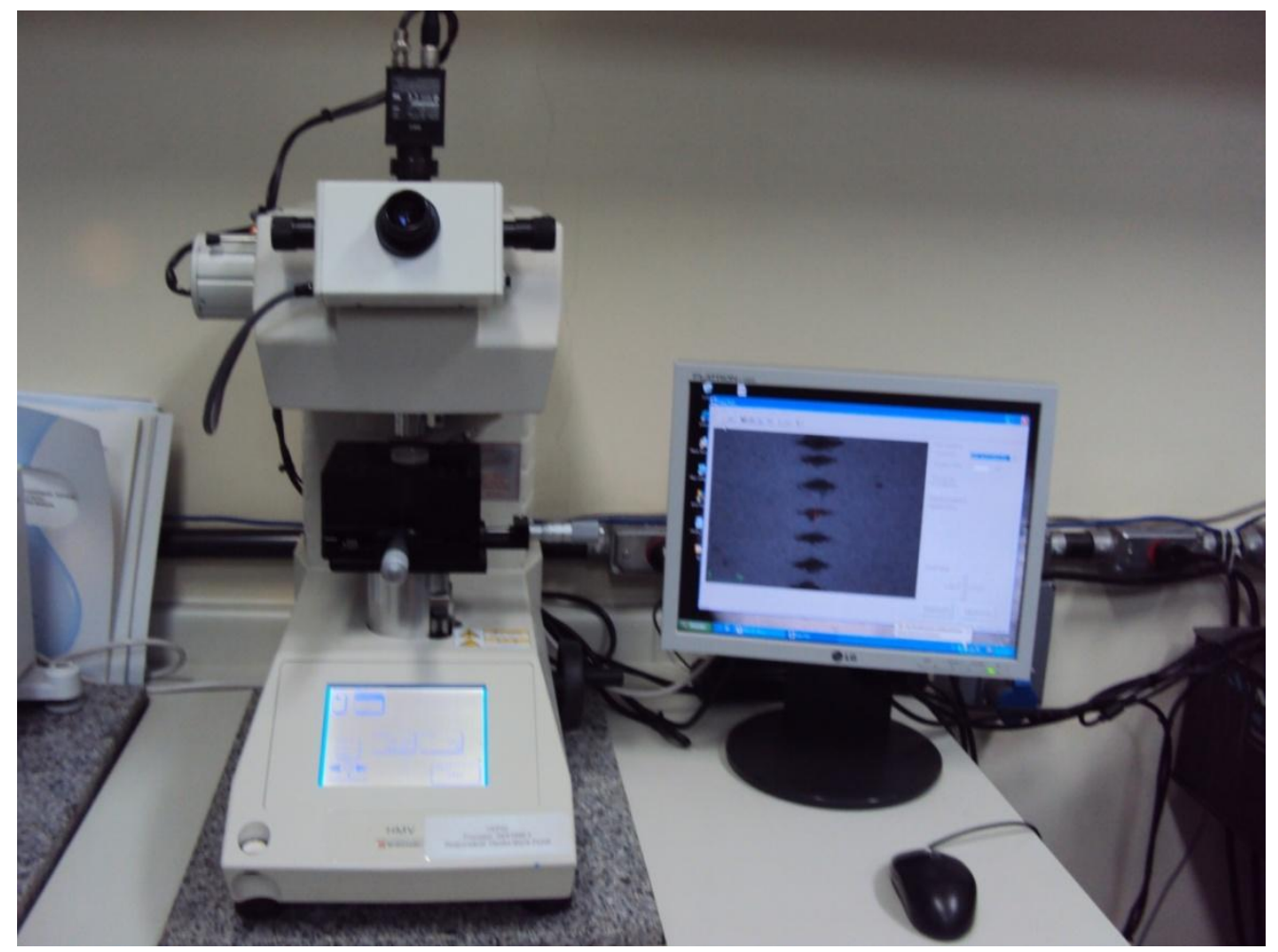

FIGURA 17: Equipamento utilizado para realizar os testes de microdureza seccional Knoop. 
$\mathrm{Na}$ porção central de cada amostra foram realizadas 3 colunas de indentações, com distância de aproximadamente $100 \mu \mathrm{m}$ entre elas. Em cada coluna foram feitas 15 indentações, à distância de 10, 20, 30, 40, 50, 60, 70, 80, $90,100,120,140,160,180$ e $200 \mu \mathrm{m}$ a partir da borda do esmalte dental (FIGURA 18). Para realização das indentações foi empregada carga de $25 \mathrm{~g}$ aplicada durante 5 segundos, de acordo com o modelo proposto por Argenta et al. ${ }^{24}$

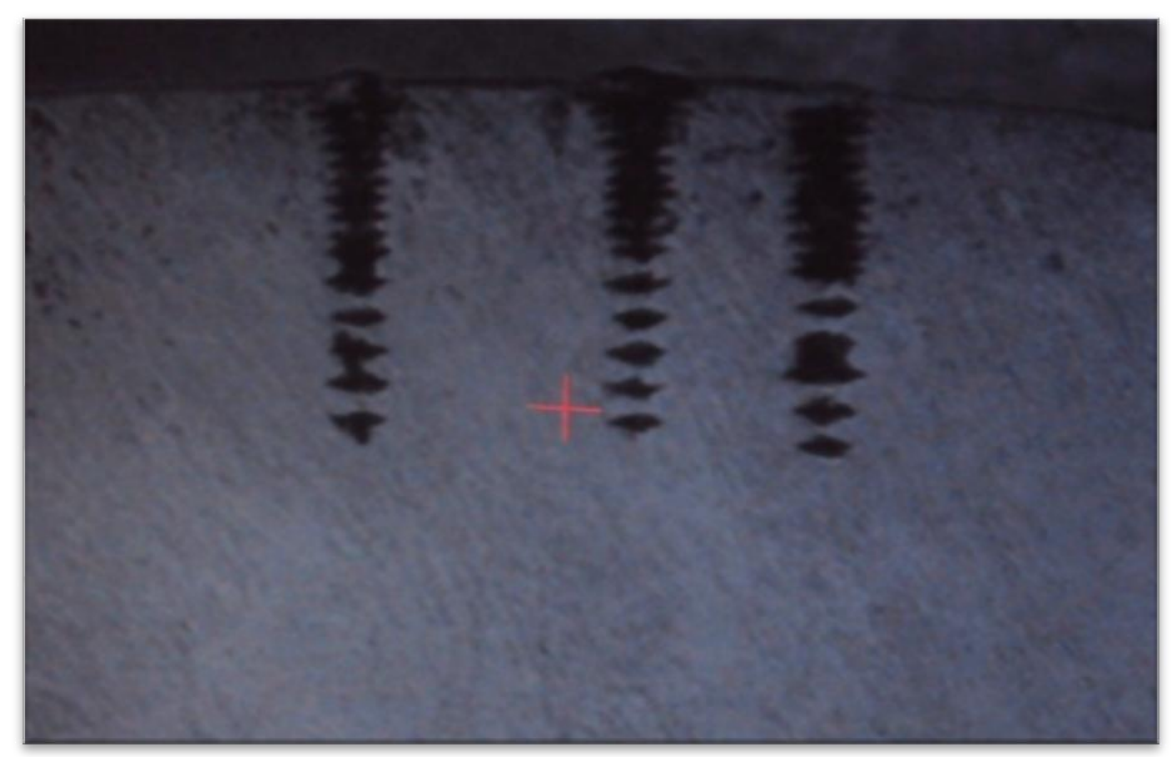

FIGURA 18: Sequência de indentações. Observa-se a presença de 3 colunas e maior distância entre as indentações de uma mesma coluna a partir da profundidade de $100 \mu \mathrm{m}$ com relação à borda de esmalte dental.

Como a dureza está relacionada com o conteúdo mineral do elemento dental, o número de dureza Knoop, fornecido automaticamente pelo programa de análise do microdurômetro, foi utilizado para avaliação do conteúdo mineral do esmalte dental. Os resultados foram anotados em tabelas de acordo com a fatia a que pertenciam e com a profundidade da indentação. Assim, para cada amostra, foi possível obter um valor médio de microdureza para cada profundidade. 


\section{RESULTADOS E DISCUSSÃO}

Os resultados obtidos através das técnicas de OCT e microdureza seccional foram analisados isoladamente e depois comparados entre si, para o estudo piloto e final. As análises estatísticas empregadas nesse estudo (t-teste para dados pareados, Anova-Tukey, Anova-Bonferroni, teste $Z$ e cálculo de coeficiente de correlação de Pearson $)^{54,55}$ foram realizadas considerando o nível de significância de 0,05 . Todas as barras apresentadas nos gráficos a seguir representam o erro padrão da medida, calculada pela propagação dos erros.

\subsection{Resultados do Experimento Piloto}

\subsubsection{Resultados de OCT}

O coeficiente de atenuação óptica total foi determinado a partir da análise do sinal de OCT das amostras, baseando-se no decaimento exponencial desse sinal, para a profundidade de 40 a $700 \mu \mathrm{m}$ no interior do esmalte. Esta faixa de profundidade foi considerada para análise porque, para a maioria das amostras, antes da profundidade de $40 \mu \mathrm{m}$ foi verificada a presença de um pico de intensidade muito alta ocasionado pela intensa refletividade da luz ao mudar de meio (do ar para o interior do dente), enquanto a partir de $700 \mu \mathrm{m}$, observou-se a extinção do sinal. Os valores dos coeficientes de atenuação médios de cada amostra foram comparados antes e depois da desmineralização provocada pela ciclagem de $\mathrm{pH}$, exceto para o grupo 0 , que foi examinado uma única vez devido ao fato de não ter sido submetido ao desafio cariogênico. Também foi realizada comparação intergrupos para verificar as diferenças entre períodos distintos de ciclagem de pH. A FIGURA 19 apresenta, como exemplo, as imagens de uma amostra, antes e depois da ciclagem de $\mathrm{pH}$. 


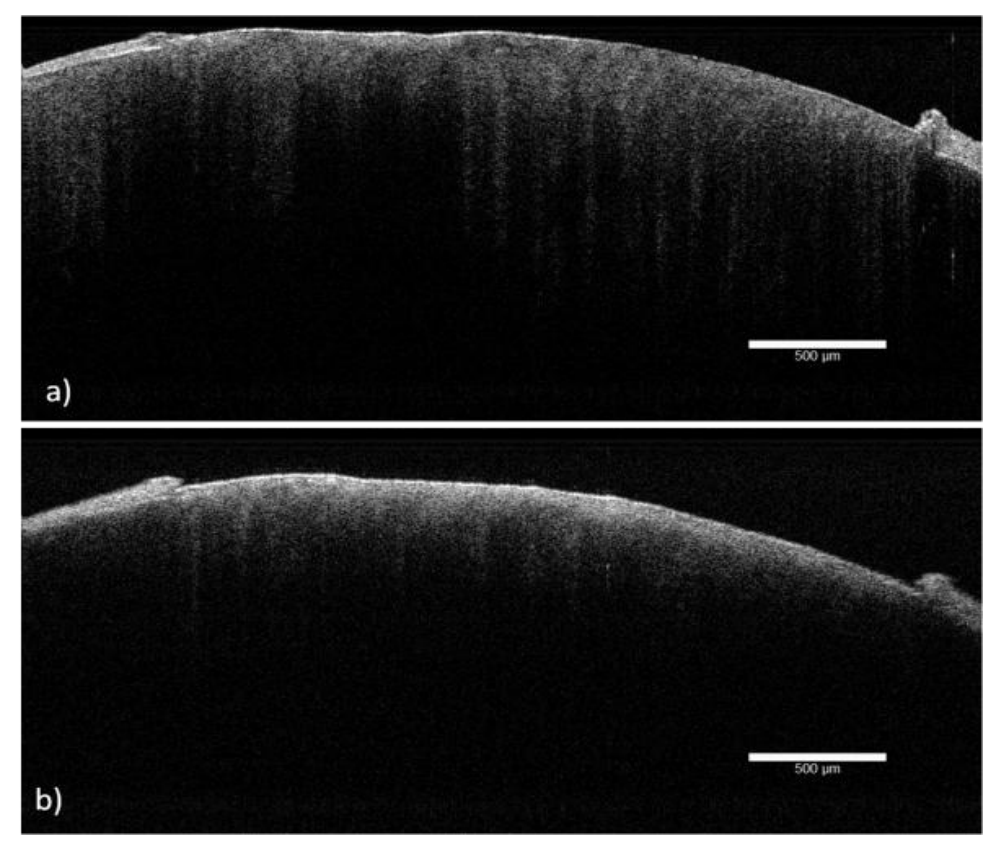

FIGURA 19- Imagens de OCT para as amostras sadia (a) e desmineralizada após 15 dias de ciclagem (b).

O coeficiente de atenuação óptica total foi maior para todas as amostras após a desmineralização, quando comparadas ao esmalte sadio. Isso ocorre porque o processo de desmineralização cria espaços vazios na estrutura do esmalte dental e desse modo, há aumento do número de interfaces, o que aumenta o espalhamento da luz.

O grupo 6, constituído por amostras submetidas a 30 dias de simulação de desafio cariogênico, foi excluído do experimento devido à erosão observada na superfície da maioria das amostras, tornando-o inviável para mimetizar lesões incipientes de cárie. Os valores médios de coeficiente de atenuação para os grupos testados estão demonstrados na FIGURA 20. Os resultados foram avaliados utilizando o t-test para dados pareados e corrigido pelo procedimento de Ryam-Holm stepdown Bonferroni. Foi observada diferença estatisticamente significante $(p<0,05)$, para todos os grupos avaliados. Os valores de $p$ encontrados foram $0,0005,0,0055,0,0110,0,0064$ e 0,0190 respectivamente para os grupos 1, 2, 3, 4 e 5 . 


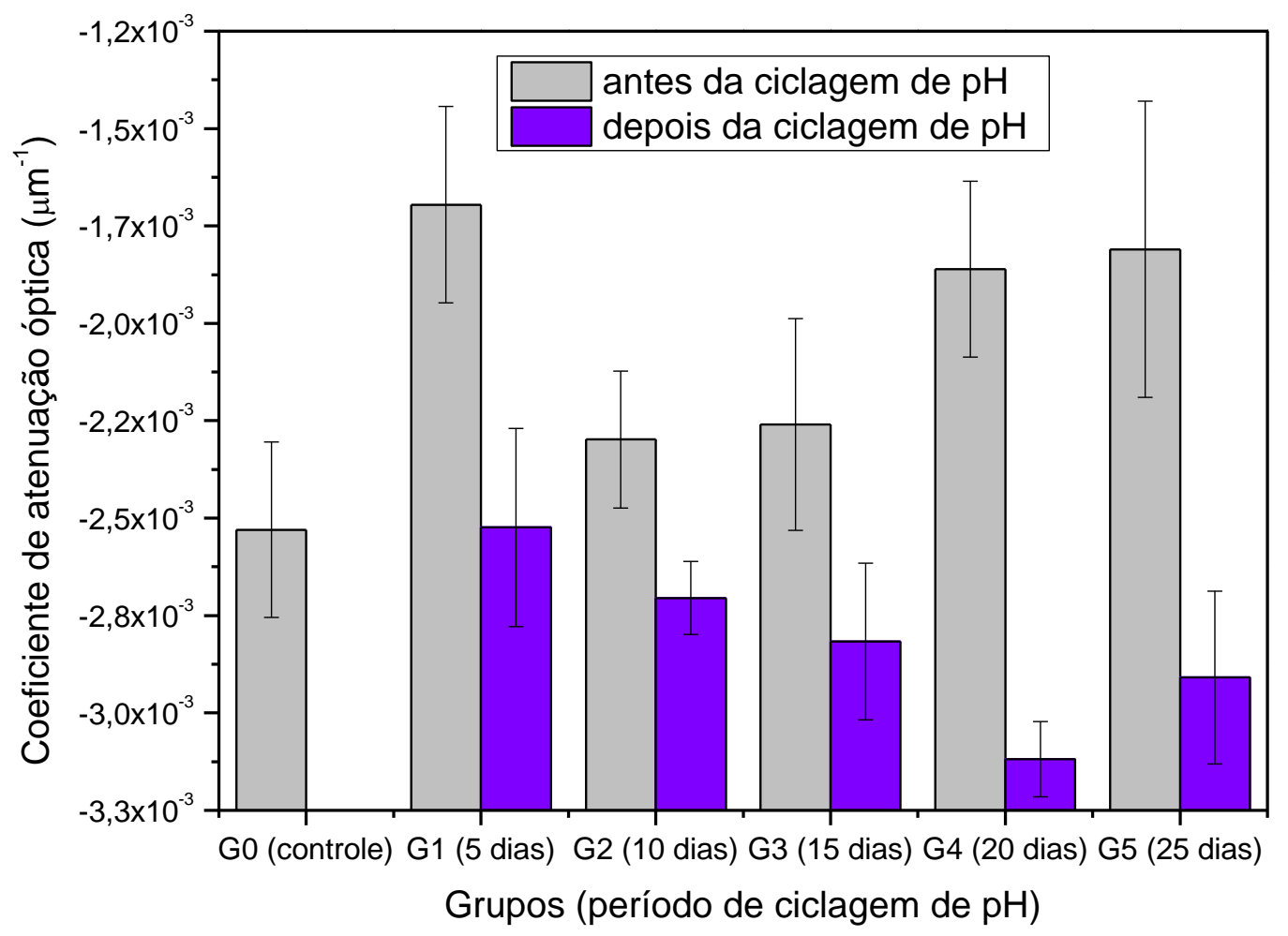

FIGURA 20: Gráfico dos coeficientes de atenuação óptica em função dos grupos antes (controle) e após a desmineralização provocada pela ciclagem de $\mathrm{pH}$. O sinal negativo das medidas indica o decaimento exponencial da intensidade do sinal de OCT.

A comparação intergrupos foi realizada utilizando a diferença entre os coeficientes de atenuação óptica obtidas antes e depois da ciclagem de $\mathrm{pH}$. Os resultados estão apresentados na FIGURA 21. 


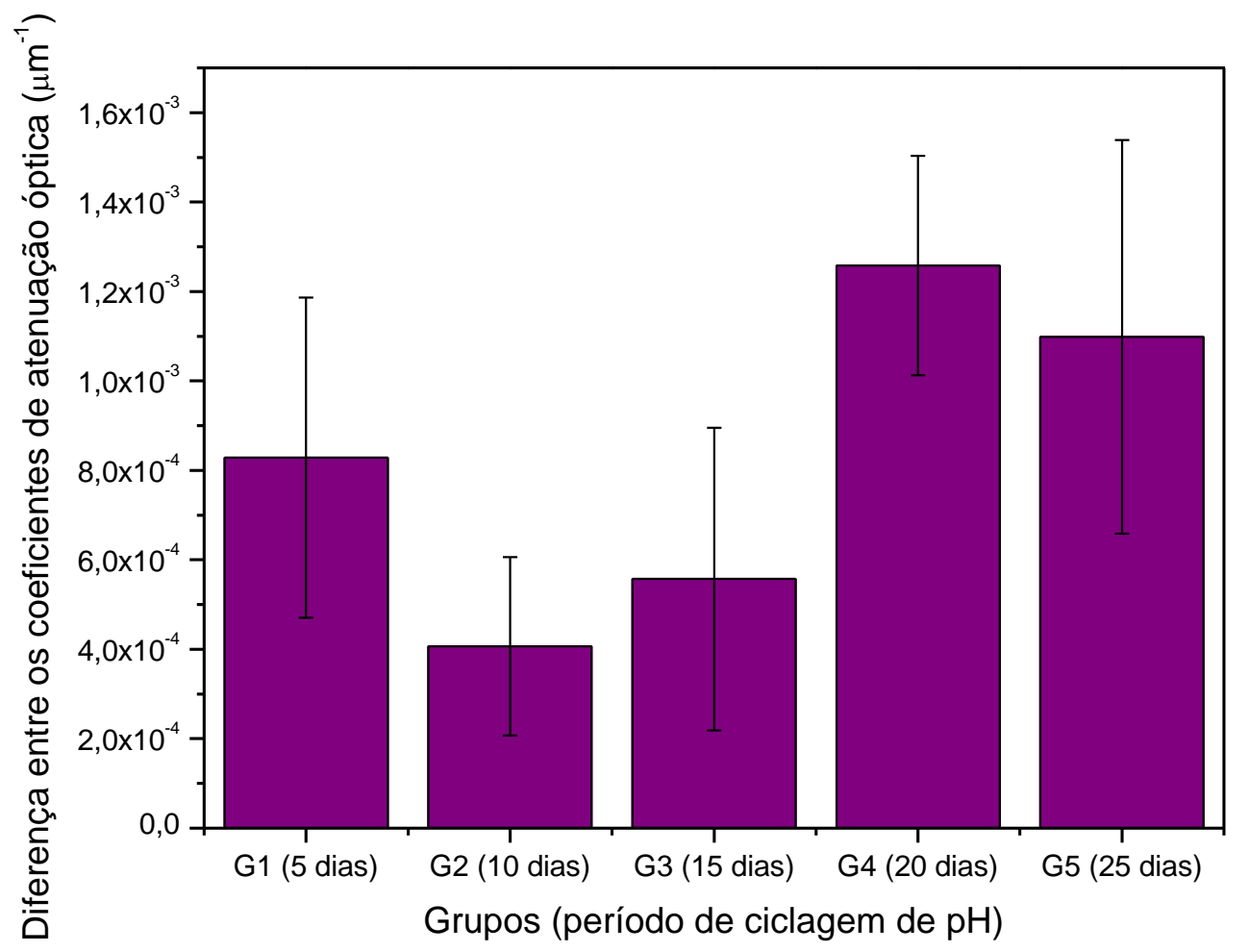

FIGURA 21: Gráfico da diferença entre os coeficientes de atenuação obtidos antes e depois da simulação do desafio cariogênico, para cada um dos grupos avaliados.

A alocação das amostras nos grupos foi aleatória, porém devido ao pequeno valor amostral utilizado para o desenvolvimento do estudo piloto e à variabilidade natural do esmalte dental humano, não foi verificado aumento significante segundo teste estatístico Anova-Tukey (exceto para o grupo 4 comparado aos grupos 2 e 3) do grau de desmineralização medido através da OCT entre os grupos analisados, o que pode ser observado pelas barras de incerteza da figura anterior.

\subsubsection{Resultados de Microdureza Seccional}

Os resultados de microdureza apresentados foram obtidos somente após o término do período de ciclagem de $\mathrm{pH}$ definido para cada grupo, devido ao caráter destrutivo do ensaio. 
Os valores de microdureza seccional Knoop foram tabulados em função da profundidade, como exemplificado na TABELA 2, para cada uma das fatias de esmalte dental obtida a partir da secção das amostras.

TABELA 2: Tabela de Valores de dureza em função da profundidade da amostra da fatia $B$, amostra 1, do grupo 3 .

\begin{tabular}{|c|c|c|c|c|c|c|}
\hline \multirow[b]{2}{*}{$\begin{array}{l}\text { Profundidade } \\
\qquad(\mu \mathrm{m})\end{array}$} & \multicolumn{6}{|c|}{ Valores de dureza de acordo com a coluna de indentação } \\
\hline & Coluna 1 & Coluna 2 & Coluna 3 & Média & $\begin{array}{l}\text { Desvio } \\
\text { padrão }\end{array}$ & $\begin{array}{c}\text { Desvio } \\
\text { padrão da } \\
\text { média (Erro } \\
\text { padrão) }\end{array}$ \\
\hline 10 & 269 & 284 & 209 & 254 & 39,68 & 22,91 \\
\hline 20 & 200 & 301 & 177 & 226 & 65,96 & 38,08 \\
\hline 30 & 297 & 277 & 365 & 313 & 46,13 & 26,63 \\
\hline 40 & 220 & 246 & 220 & 228,6 & 15,01 & 8,67 \\
\hline 50 & 225 & 255 & 209 & 229,6 & 23,35 & 13,48 \\
\hline 60 & 255 & 243 & 234 & 244 & 10,54 & 6,08 \\
\hline 70 & 259 & 225 & 240 & 241,3 & 17,04 & 9,84 \\
\hline 80 & 259 & 292 & 333 & 294,6 & 37,07 & 21,40 \\
\hline 90 & 220 & 252 & 255 & 242,3 & 19,40 & 11,20 \\
\hline 100 & 323 & 281 & 207 & 270,3 & 58,73 & 33,91 \\
\hline 120 & 389 & 409 & 222 & 340 & 102,67 & 59,28 \\
\hline 140 & 343 & 328 & 338 & 336,3 & 7,63 & 4,41 \\
\hline 160 & 354 & 323 & 277 & 318 & 38,74 & 22,37 \\
\hline 180 & 305 & 288 & 349 & 314 & 31,48 & 22,37 \\
\hline 200 & 349 & 323 & 297 & 323 & 26 & 15,01 \\
\hline
\end{tabular}

Foram calculadas médias de valores de microdureza de todas as amostras para as profundidades avaliadas, considerando o peso estatístico de cada medida, devido ao fato de haver 4 fatias para cada amostra. Os resultados foram expressos em gráficos de valores de microdureza em função da profundidade, como apresentado na FIGURA 22 , para cada uma das amostras. 


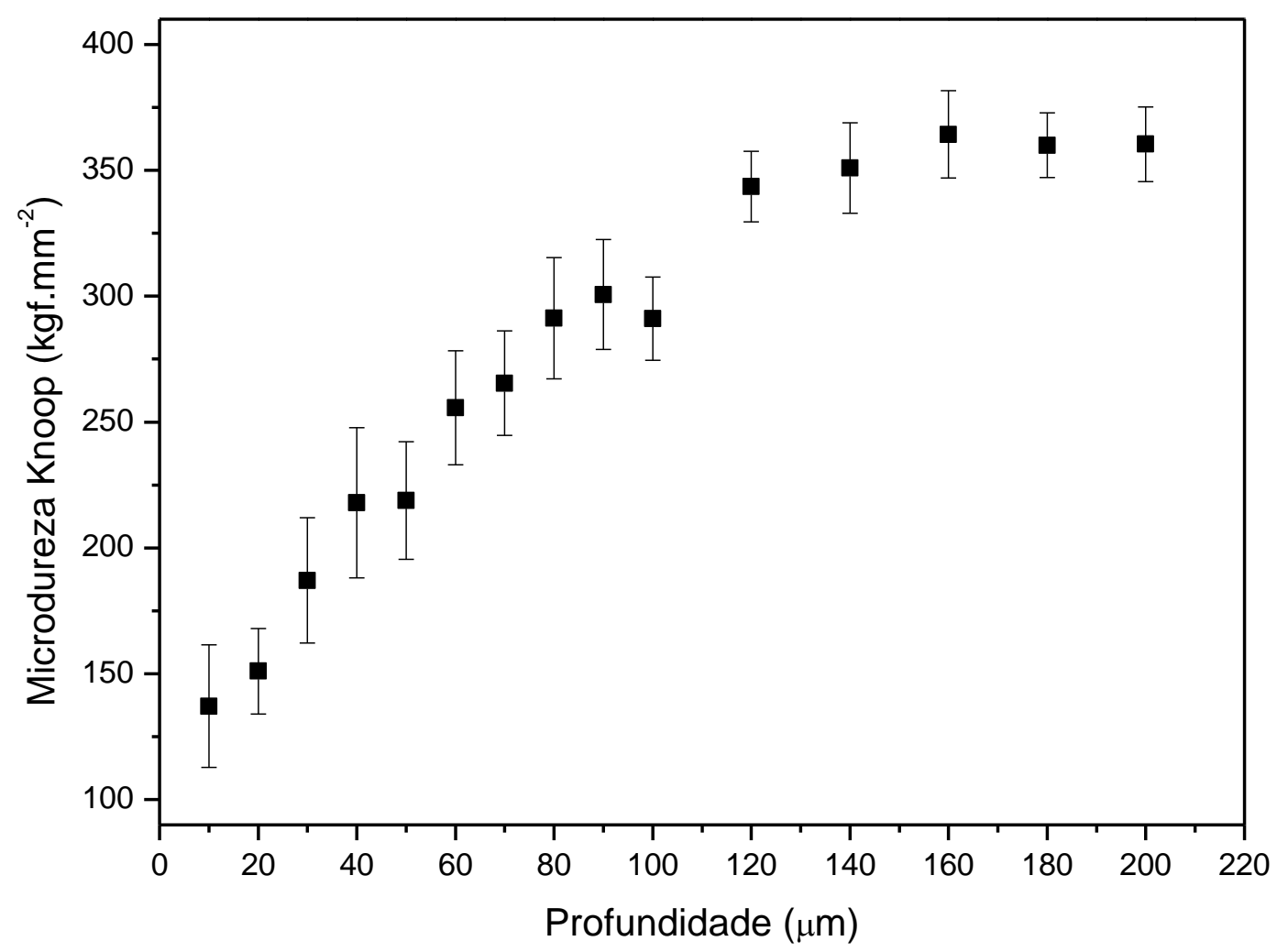

FIGURA 22: Gráfico dos valores de microdureza em função da profundidade das indentações no esmalte dental, para a amostra 6 do grupo 3.

Na figura acima é possível observar que os valores de microdureza seccional aumentam com a profundidade até aproximadamente $120 \mu \mathrm{m}$ e, a partir desta, sofrem pouca variação. O mesmo comportamento foi observado em todas as amostras, o que nos permite inferir que o método de ciclagem utilizado promoveu desmineralização até esta profundidade do esmalte dental. Foram calculados os valores médios de microdureza em função da profundidade para cada um dos grupos. Os resultados estão apresentados na FIGURA 23. 


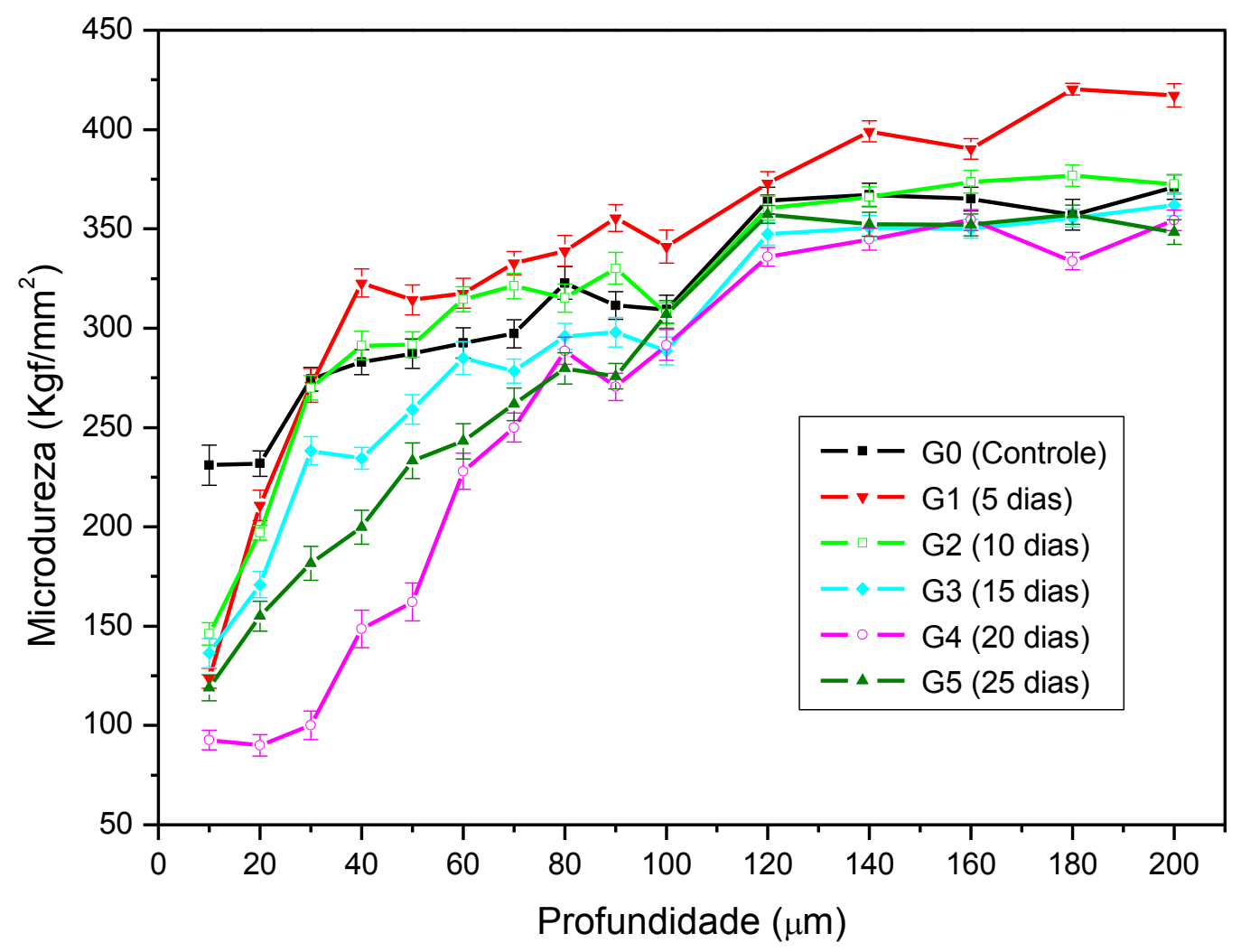

FIGURA 23: Gráfico dos valores médios de microdureza em função da profundidade para os grupos de análise. Maior variação dos valores de microdureza é observada até a profundidade de $120 \mu \mathrm{m}$.

Os menores valores de microdureza foram encontrados para o grupo 4 (20 dias de ciclagem), o que sugere maior desmineralização desse grupo. Embora fosse esperado que o grupo 5 apresentasse a maior desmineralização, em decorrência ao maior tempo a que o grupo foi submetido ao desafio cariogênico simulado, parte das lesões foi perdida durante o corte das amostras, provavelmente, devido à elevada desmineralização dessas. Assim, as indentações foram realizadas na porção remanescente, a qual apresenta maior conteúdo mineral. Além disso, a não visualização de perda de dureza gradativa em função dos dias de ciclagem de $\mathrm{pH}$ pode ser decorrente do pequeno valor amostral associado à variabilidade natural do esmalte.

Para comparar a desmineralização em diferentes tempos de ciclagem foram considerados os valores de microdureza obtidos até a profundidade de 120 
$\mu \mathrm{m}$, visto que a partir desta, não há indícios de perda mineral. Essa mesma profundidade de lesão foi observada por Fried et al.(2002) ${ }^{2}$ em seu estudo utilizando microscopia, após 14 dias de ciclagem de pH utilizando o método de ciclagem proposto por Featherstone et al. $(1986)^{23}$. Os valores médios de microdureza para toda a profundidade considerada estão representados na FIGURA 24.

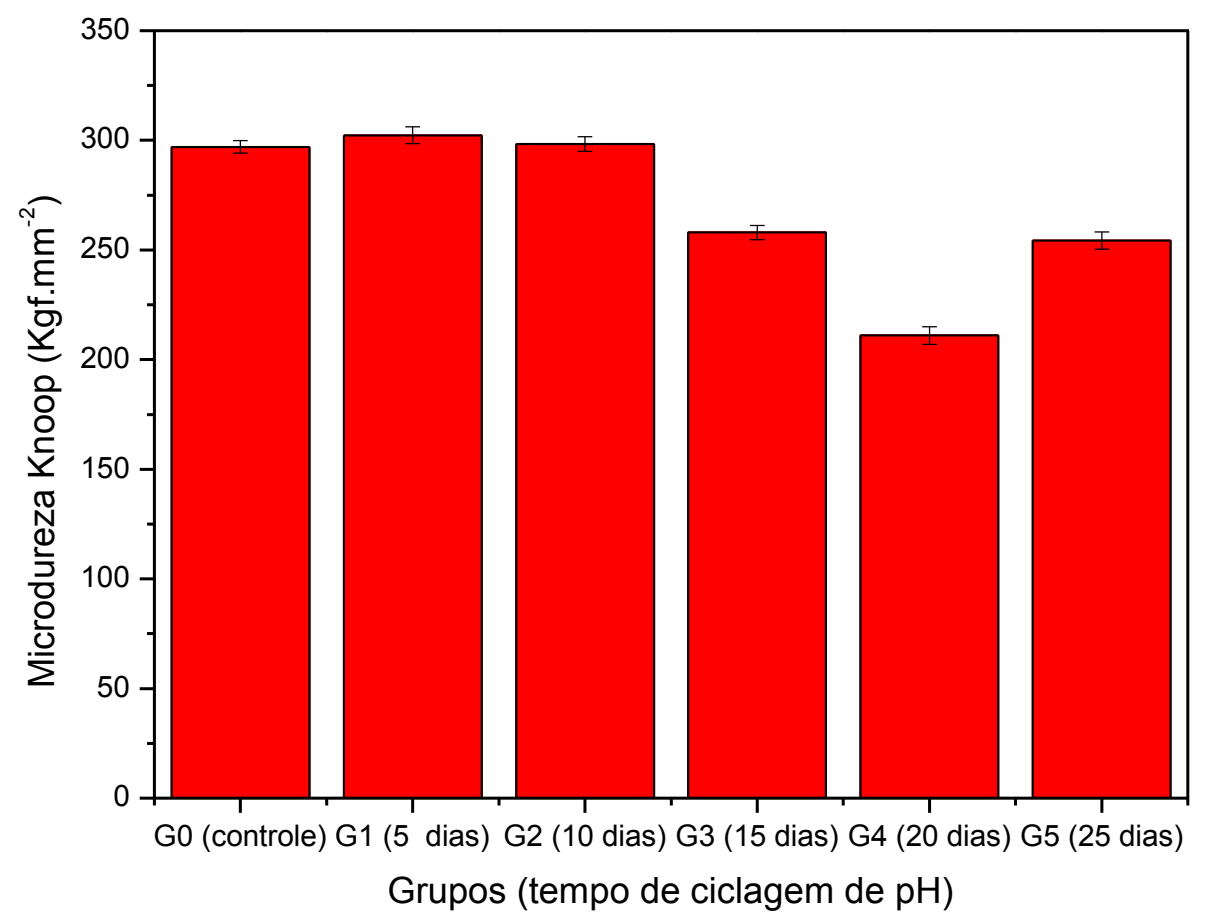

FIGURA 24: Média de valores de microdureza seccional de cada um dos grupos, para profundidades de 10 a $120 \mu \mathrm{m}$.

Os resultados acima foram analisados utilizando o teste estatístico Anova-Tukey. Foi observada diferença significante, com valor de $\mathrm{p}$ menor que 0,05, entre o grupo 4 (20 dias de ciclagem de pH) e os Grupos 0 (controle), 1 e 2 submetidos, respectivamente, a 5 e 10 dias de ciclagem de $\mathrm{pH}$. Não foi verificada diferença estatística para as demais comparações entre os grupos.

A alteração de minerais também foi mensurada por diferença de áreas nos gráficos de microdureza por profundidade, conforme apresentado na FIGURA 25. A diferença entre as áreas sob a curva da região saudável e desmineralizada representa a perda mineral. 


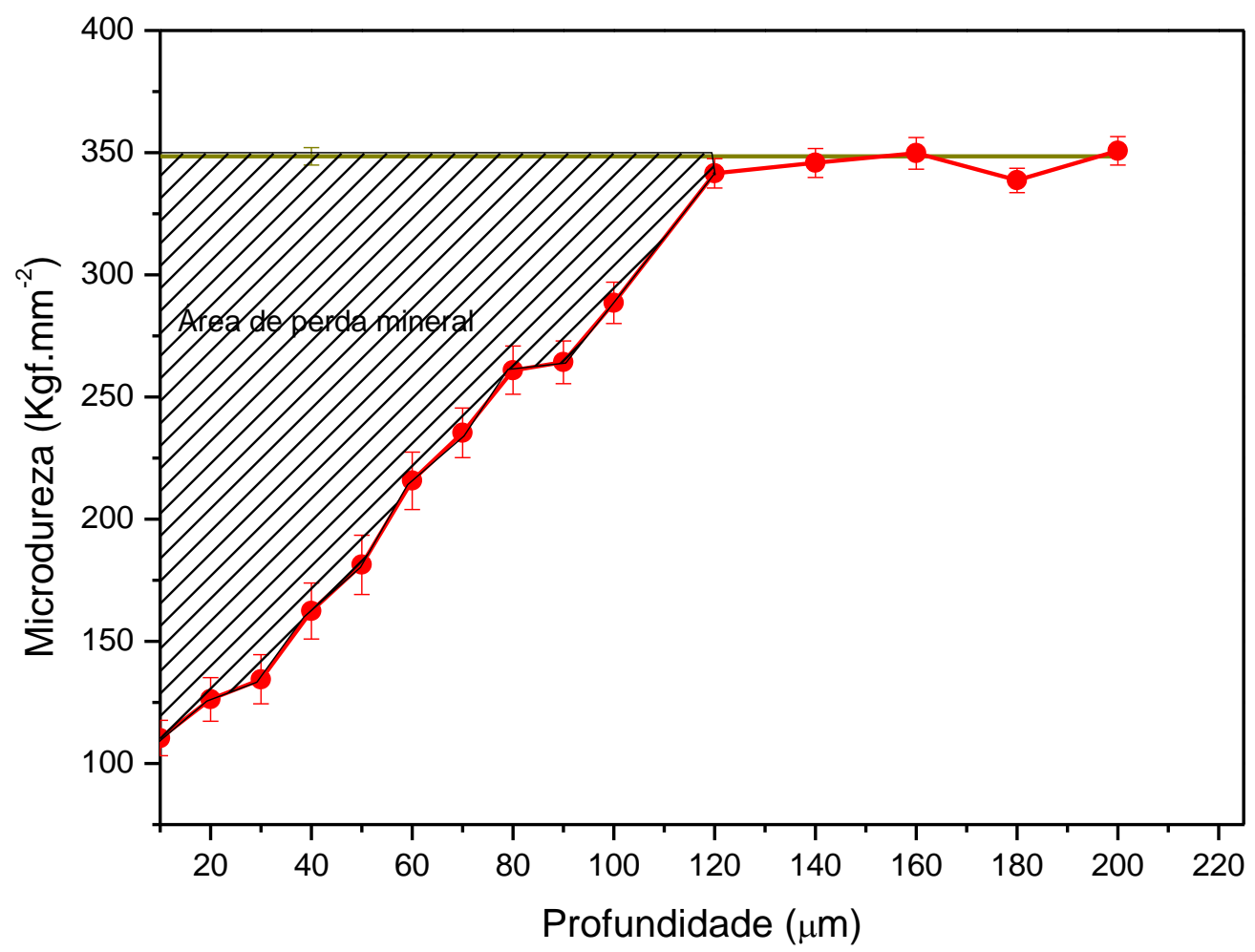

FIGURA 25: Valores de microdureza em função da profundidade para amostra 1 do grupo 4. A área contida entre a linha preta (valor médio de microdureza da região saudável) e a linha vermelha (valores de microdureza para regiões desmineralizadas) representa o conteúdo mineral perdido pela amostra após desafio cariogênico.

As áreas relacionadas à perda mineral foram comparadas para avaliar se houve desmineralização em diferentes estágios através do modelo de simulação de cáries adotado (FIGURA 26). 


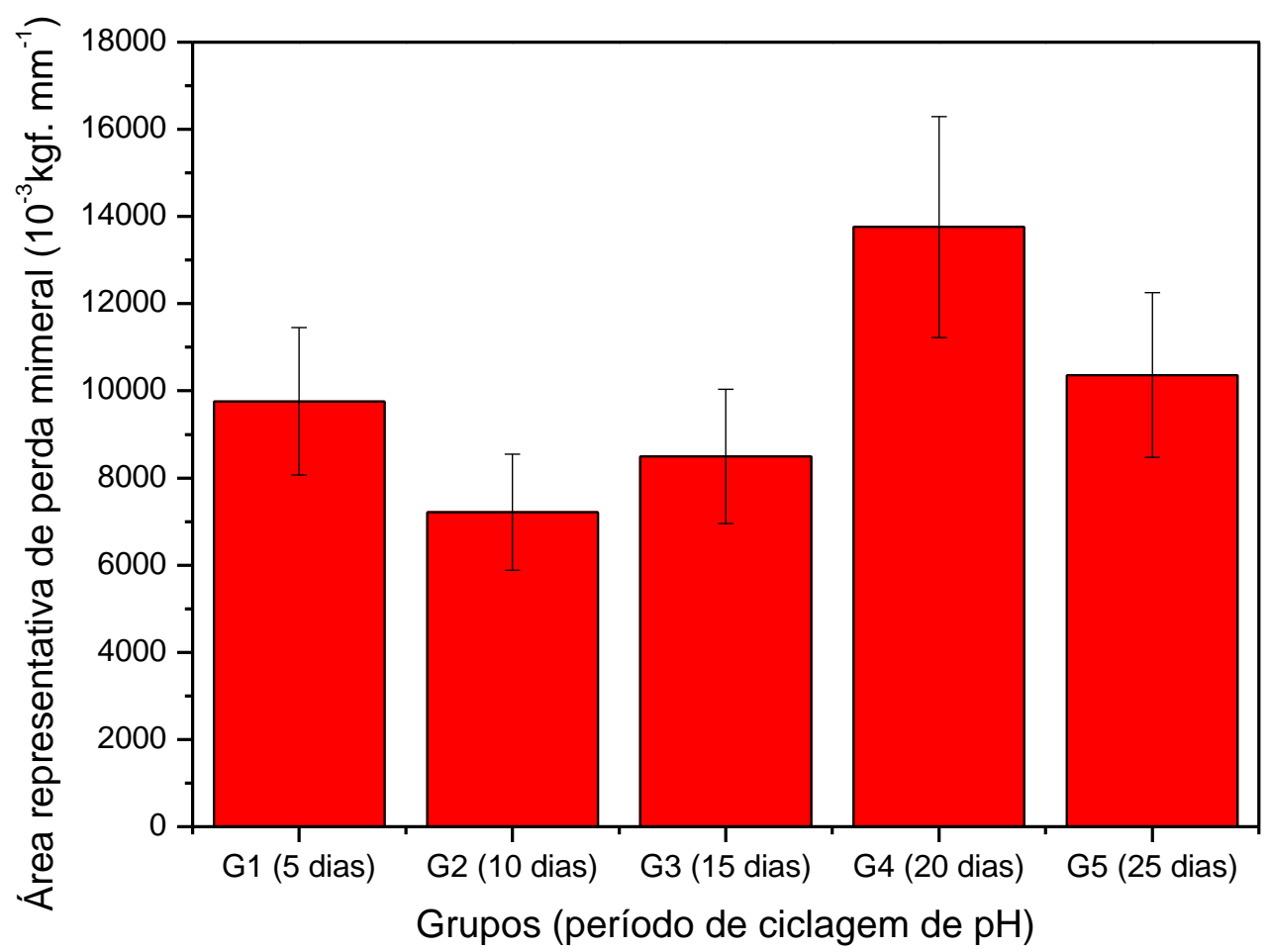

FIGURA 26 - Desmineralização obtida pela diferença de áreas sobre e sob a curva em gráficos de microdureza por profundidade, para cada grupo. Maior perda mineral foi observada no grupo 4.

A comparação intergrupos para perda mineral foi realizada por meio do teste-Z e os valores de $\mathrm{p}$ foram corrigidos para múltiplas comparações pelo procedimento de Ryan-Holm stepdown Bonferroni. Foi encontrada diferença estatística significante somente entre os grupos 2 e 4, com valor de p igual a 0,04.

De acordo com os resultados de microdureza apresentados, não foi possível verificar o desenvolvimento de diferentes estágios de desmineralização através do modelo utilizado para simulação de lesões de cárie.

\subsubsection{Comparação entre os resultados de OCT e Microdureza seccional}

Para comparação entre as técnicas de OCT e microdureza seccional foram utilizados as médias de coeficiente de atenuação e de microdureza apresentadas pelos grupos ao término do período de ciclagem de $\mathrm{pH}$. Foi observada relação direta entre os resultados comparados, como demonstrado na FIGURA 27. 


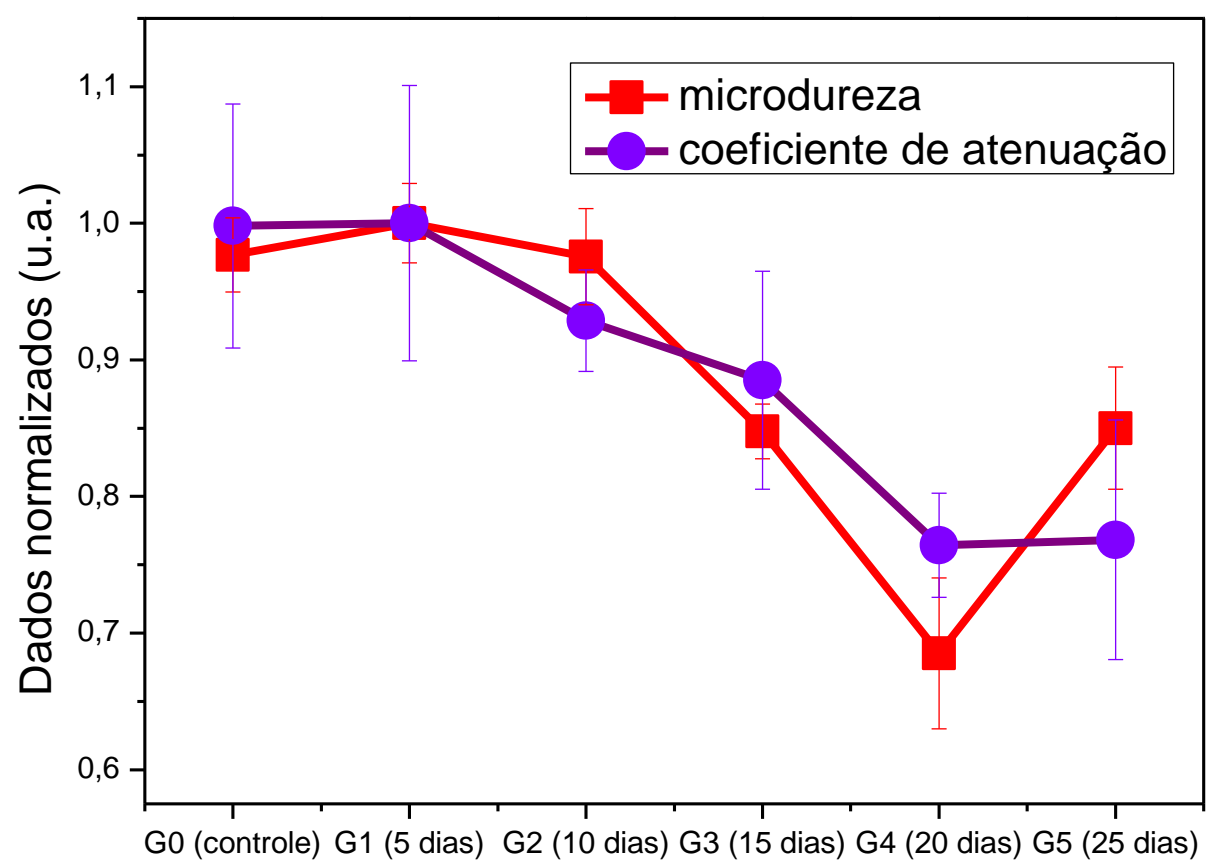

Grupos (período de ciclagem de $\mathrm{pH}$ )

FIGURA 27: Resultados médios de microdureza seccional obtidos até a profundidade de $120 \mu \mathrm{m}$ e de coeficientes de atenuação óptica normalizados pelo maior valor apresentados para cada técnica.

Os resultados obtidos a partir da técnica de OCT apresentaram comportamento similar aos de microdureza, exceto para o grupo 5 , devido à impossibilidade de realizar leitura das indentações em regiões de desmineralização mais intensa. A relação de proporcionalidade observada demonstra o potencial da técnica de OCT para avaliação de conteúdo mineral em esmalte dental.

As técnicas empregadas neste estudo também foram confrontadas quanto à capacidade em detectar perdas minerais. As diferenças entre os coeficientes de atenuação óptica, obtidos antes e depois do desafio cariogênico simulado, foram comparadas às áreas representativas de perda mineral, obtidas a partir dos gráficos de microdureza Knoop em função da profundidade. Os resultados dessa análise estão apresentados na FIGURA 28. 


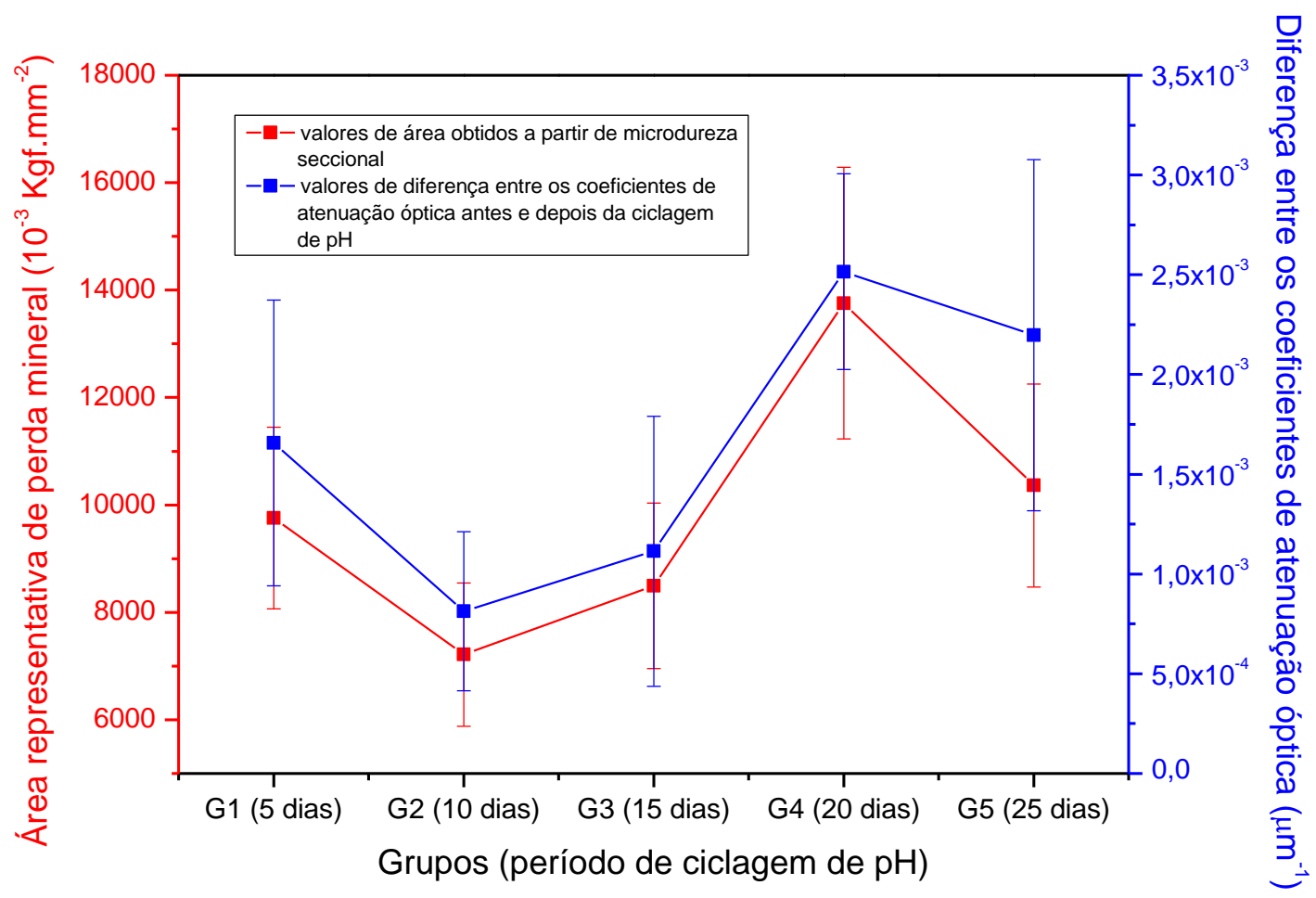

FIGURA 28: Comparação entre os resultados provenientes de testes de microdureza seccional e de OCT, para avaliação de conteúdo de perda mineral.

Na figura acima é possível observar a congruência dos resultados entre as técnicas empregadas no estudo, para avaliação de desmineralização dental. Assim como na FIGURA 27, o grupo 5 apresentou comportamento distinto dos demais grupos, devido aos problemas relacionados ao teste de microdureza seccional anteriormente citados. Para avaliar a concordância entre as técnicas para detecção de desmineralização, foi calculado o coeficiente de correlação de Pearson, conforme a equação:

$$
\rho=\frac{\operatorname{cov}(\mathrm{X}, \mathrm{Y})}{\sqrt{\operatorname{varX} \cdot \operatorname{varY}}}
$$

onde, $\rho$ é o coeficiente de correlação de Pearson, $X$ é área calculada a partir do exame de microdureza e $Y$ a diferença do coeficiente de atenuação óptica antes e depois da ciclagem de $\mathrm{pH}$, cov é covariância e var, representa a variância. Foi encontrado valor de $\rho$ de 0,93, o que indica forte correlação entre as técnicas analisadas. 
Após o término dos experimentos do estudo piloto e análise dos resultados, foi observada necessidade de correção do programa de análise de OCT, para converter a intensidade do sinal apresentado em escala logarítmica (decibéis $(\mathrm{dB})$ ) para a escala linear. Dessa forma, todas as imagens de OCT foram novamente analisadas utilizando-se a versão corrigida do programa e os resultados foram novamente comparados aos resultados de microdureza, para as mesmas profundidades analisadas com a versão anterior, ou seja, considerando a profundidade de 10 a $120 \mu \mathrm{m}$ para a microdureza e de 40 a $700 \mu \mathrm{m}$ para intensidade de sinal de OCT.

Foram comparadas as médias de coeficiente de atenuação e microdureza apresentadas pelos grupos após o término do período de ciclagem de $\mathrm{pH}$, conforme apresentado na FIGURA 29.

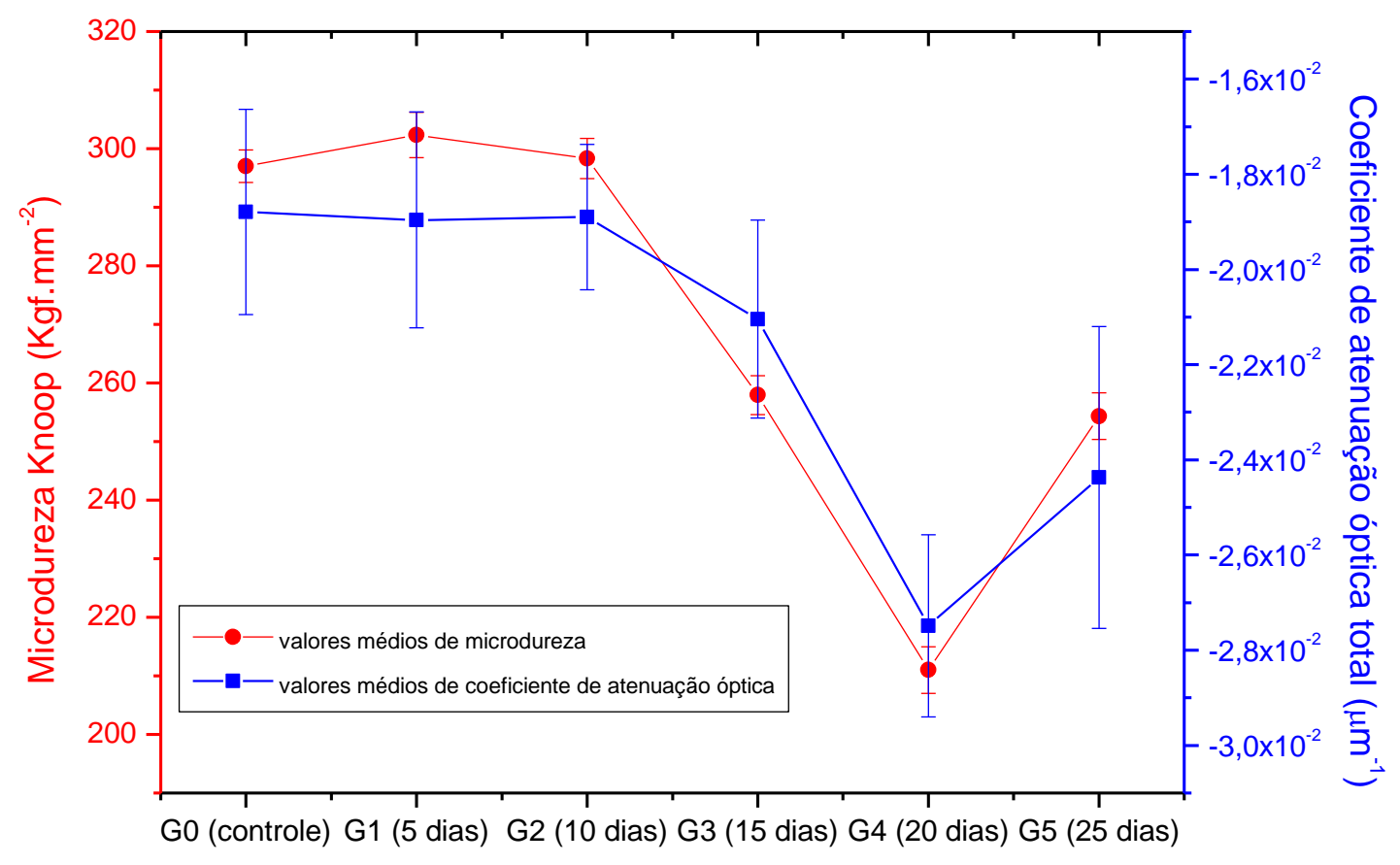

Grupos (tempo de ciclagem de $\mathrm{pH}$ )

FIGURA 29: Resultados médios de microdureza seccional obtidos até a profundidade de $120 \mu \mathrm{m}$ e de coeficiente de atenuação óptica para a profundidade de 40 a $700 \mu \mathrm{m}$. O sinal negativo associado aos valores de coeficiente de atenuação óptica refere-se ao decaimento exponencial da intensidade do sinal de OCT. 
$\mathrm{Na}$ figura anterior é possível observar que as técnicas comparadas apresentam o mesmo comportamento em relação aos tempos de ciclagem a que os grupos foram submetidos e também, são semelhantes aos apresentados na FIGURA 27, antes da correção do programa de análise dos dados de OCT, verificando-se alterações somente nos valores absolutos das médias de coeficiente de atenuação óptica total.

A diferença entre os valores de coeficiente de atenuação obtidos antes e depois do desafio cariogênico também foram reavaliados e comparados com os resultados de área sobre a curva provenientes dos gráficos de microdureza em função da profundidade (FIGURA 30), a fim de verificar a concordância entre as técnicas, após a correção do sinal de OCT.

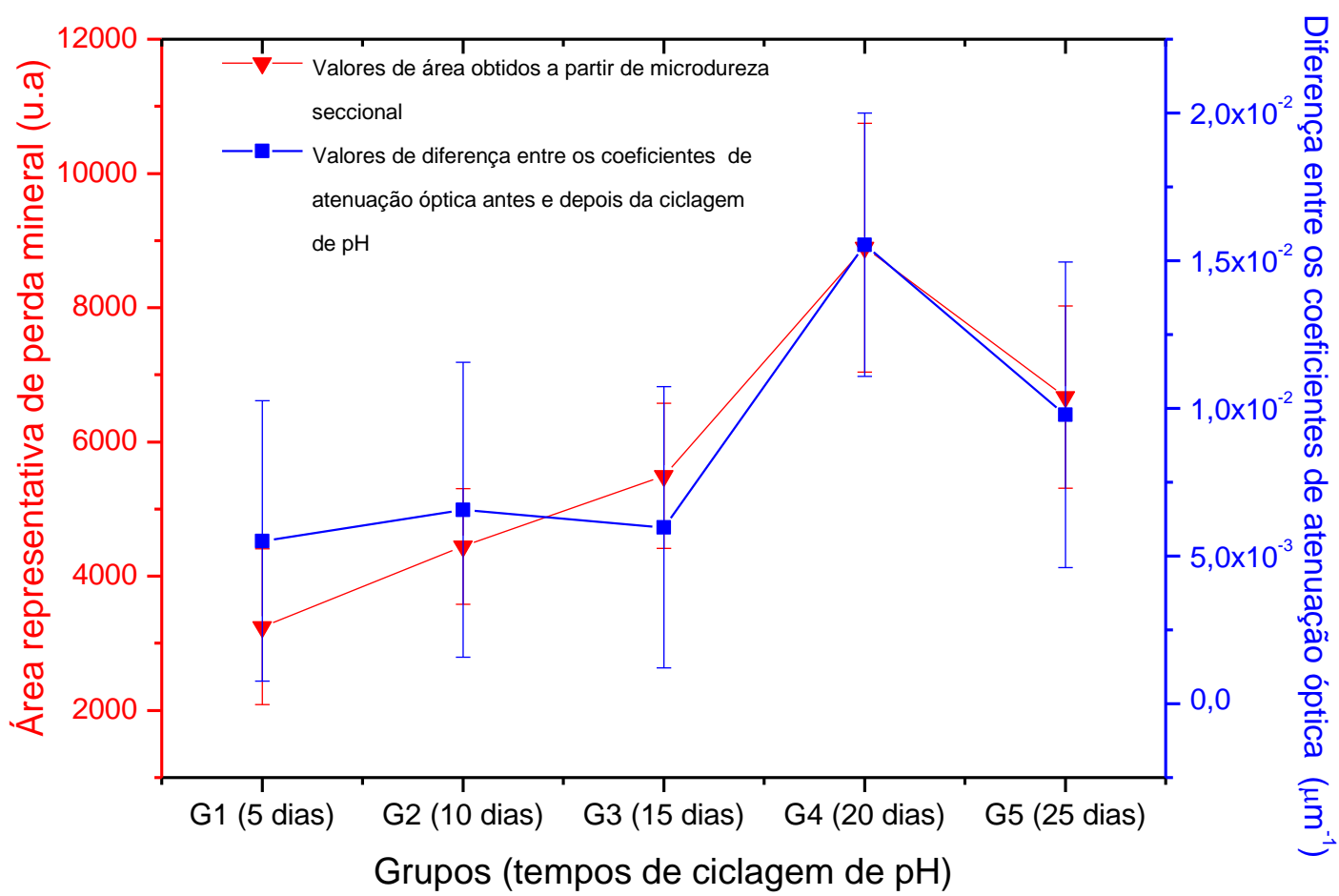

FIGURA 30: Comparação entre os resultados provenientes de testes de microdureza seccional, para a profundidade de 10 a $120 \mu \mathrm{m}$ e de OCT de 40 a $700 \mu \mathrm{m}$, para avaliação de conteúdo de perda mineral.

$\mathrm{Na}$ figura anterior, os resultados apresentados demonstram similaridade entre as técnicas avaliadas para avaliação de alteração de conteúdo 
mineral, de maneira semelhante ao observado no gráfico da FIGURA 28, sem correção do sinal de OCT.

Os resultados obtidos a partir da técnica de microdureza seccional detectaram menor conteúdo mineral até a profundidade de $120 \mu \mathrm{m}$, enquanto que o coeficiente de atenuação óptica total só pode ser adquirido a partir de $40 \mu \mathrm{m}$, devido à influência da forte refletividade da luz na intensidade do sinal detectado. Assim, para comparar as duas técnicas para avaliação da mesma região da amostra, as imagens de OCT foram novamente analisadas considerando-se o decaimento da intensidade do sinal de OCT para a profundidade de 40 a $120 \mu \mathrm{m}$ e os resultados foram comparados aos de microdureza para a mesma profundidade, conforme apresentado na FIGURA 31.

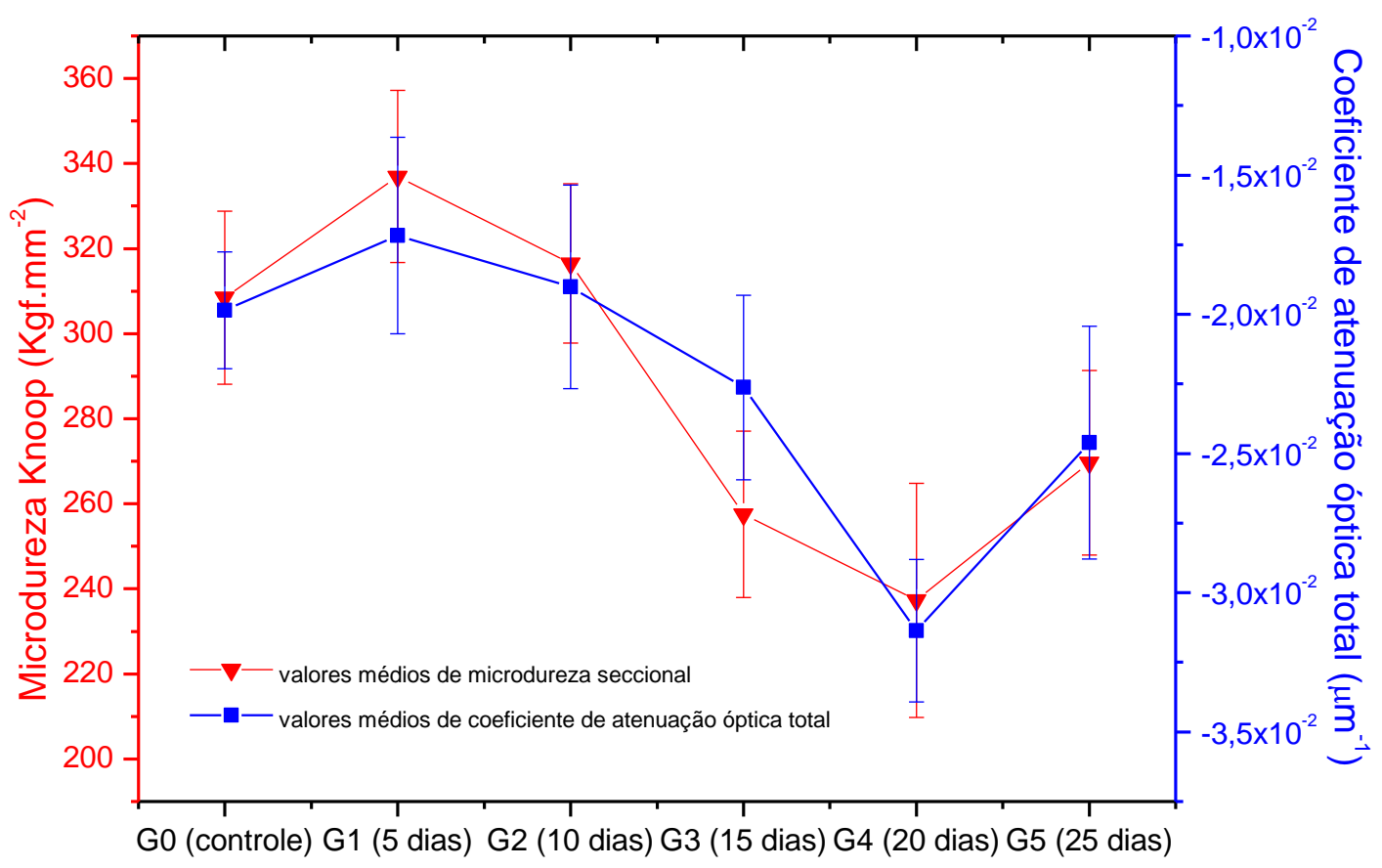

Grupos (tempo de ciclagem de $\mathrm{pH}$ )

FIGURA 31: Valores médios de microdureza seccional e de coeficiente de atenuação óptica total, para a profundidade de 40 a $120 \mu \mathrm{m}$. O sinal negativo associado aos valores de coeficiente de atenuação óptica refere-se ao decaimento exponencial da intensidade do sinal de OCT. 
Os resultados obtidos a partir das técnicas de microdureza e de OCT apresentaram comportamento similar, conforme observado na figura acima. A mesma congruência de resultados foi observada ao comparar profundidades diferentes de OCT e microdureza, conforme apresentado na FIGURA 27, o que indica que há relação entre o sinal de OCT e os valores médios de microdureza, comparando-se as mesmas profundidades de análise, ou considerando-se o sinal de OCT até sua extinção, que ocorre para a profundidade de $700 \mu \mathrm{m}$.

As técnicas de OCT e microdureza também foram comparadas quanto às diferenças detectadas antes e depois da simulação do desafio cariogênico, representadas pelas áreas obtidas a partir dos gráficos de microdureza em função da profundidade e pelas diferenças entre os coeficientes de atenuação óptica total, conforme apresentado na FIGURA 32.

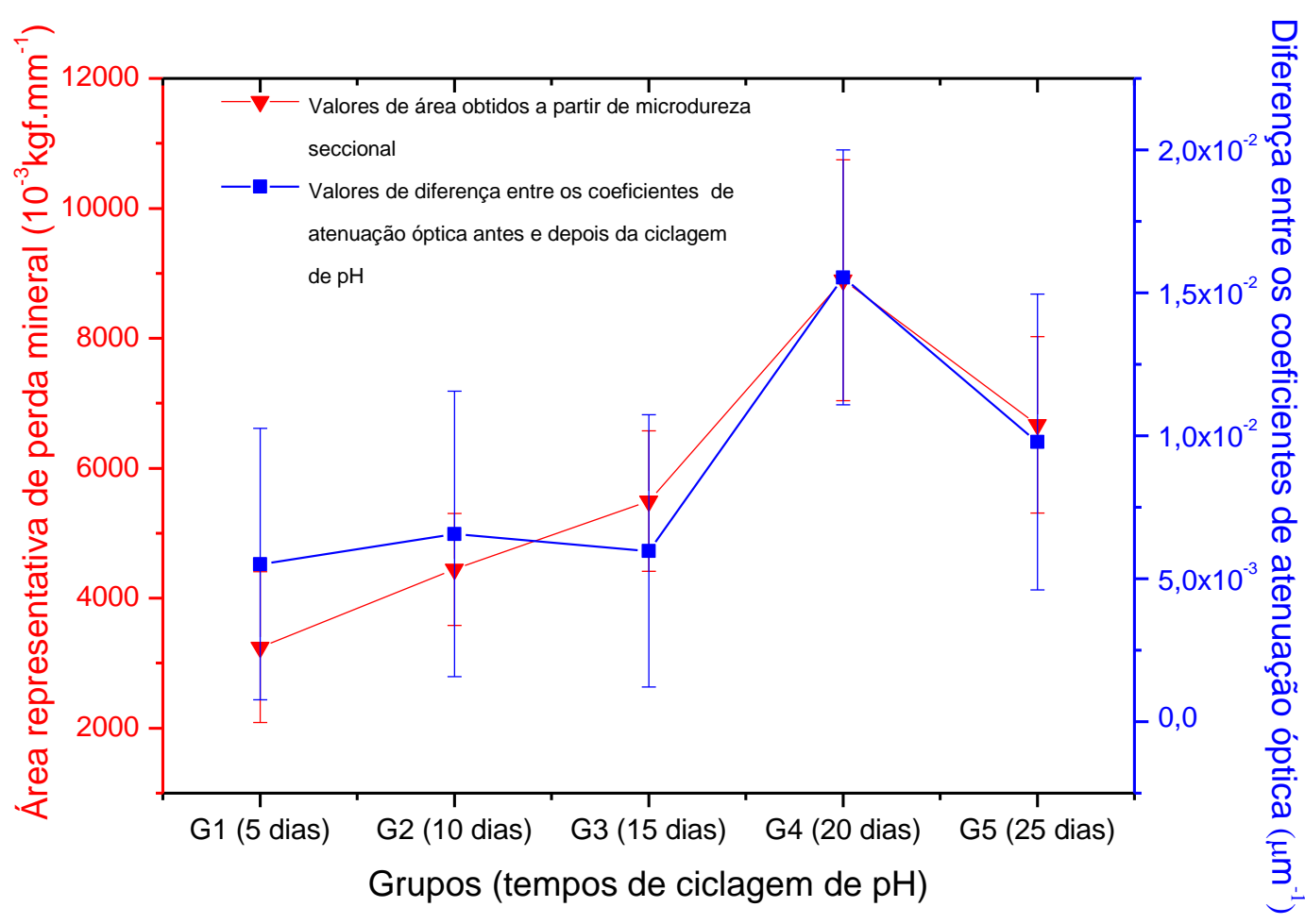

FIGURA 32: Comparação entre os resultados provenientes de testes de microdureza seccional e OCT, ambos para a profundidade de 40 a $120 \mu \mathrm{m}$ para avaliação de alteração de conteúdo de perda mineral.

Os resultados de OCT e microdureza apresentaram comportamento similar em relação ao período de ciclagem de $\mathrm{pH}$ a que os grupos foram submetidos, exceto para o grupo 1, no qual verificou-se menor concordância entre 
as técnicas comparadas, conforme observado na figura anterior. O coeficiente de correlação de Pearson obtido através da comparação dos resultados foi de 0,93, o mesmo obtido através da comparação das técnicas sem a correção do sinal de OCT e considerando-se as profundidades de 10 a $120 \mu \mathrm{m}$ para microdureza e de 40 a $700 \mu \mathrm{m}$ para OCT, o que indica que esses parâmetros exercem pouca influência sobre os resultados encontrados, por representarem o comportamento médio da microdureza e do coeficiente de atenuação óptica.

\subsection{Resultados do Experimento Final}

Considerando-se os resultados obtidos no estudo piloto, foram realizadas algumas alterações na metodologia do experimento final. Devido ao fato de não ser verificada diferença entre os grupos controle, 5 e 10 dias de ciclagem de $\mathrm{pH}$ no estudo piloto, associado a necessidade de maior número amostral por grupo e a limitação do número de dentes para a realização do experimento, foram definidos 4 grupos, com diferença de 7 dias no período de ciclagem de $\mathrm{pH}$ a que foram submetidos. As análises de OCT foram realizadas com a versão corrigida do programa de análise. A FIGURA 33 apresenta o sinal de OCT em dB e corrigido para a escala linear.

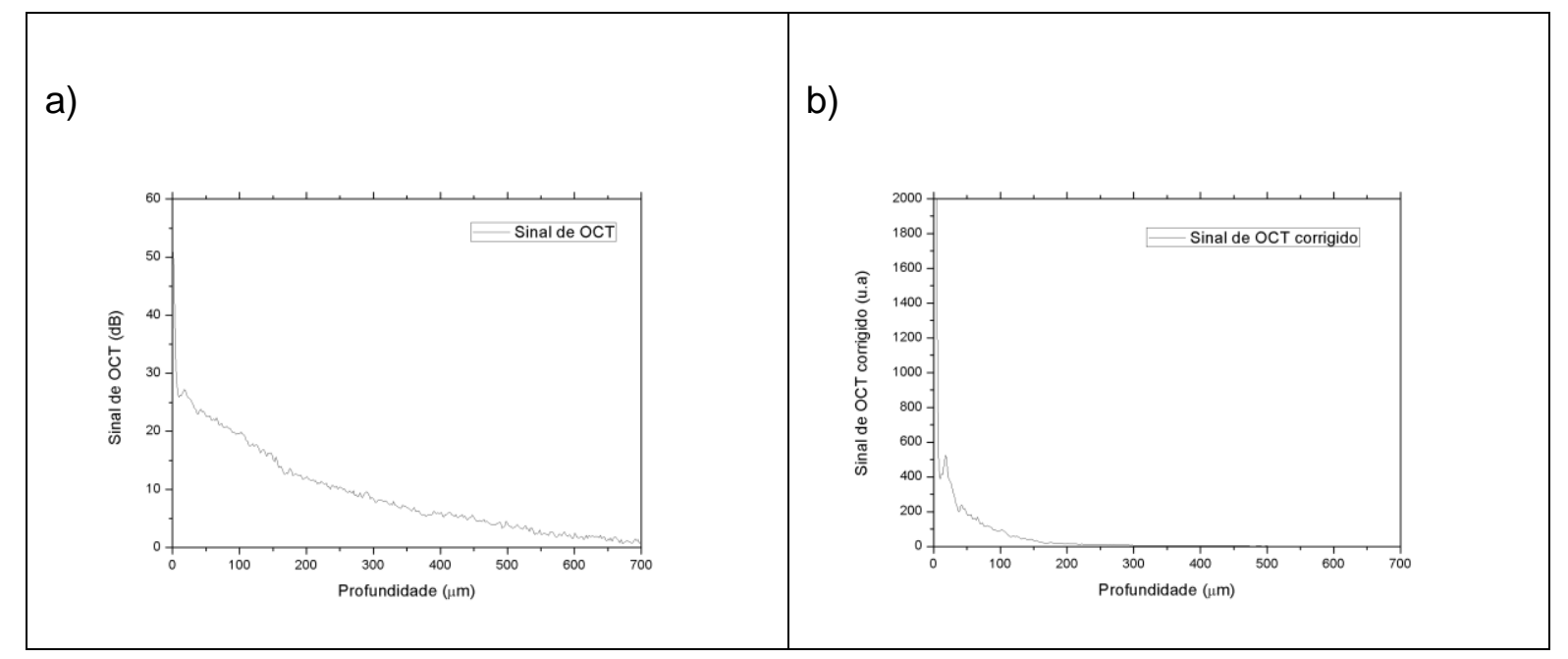

FIGURA 33: a) Sinal original do OCT em dB, b) Sinal de OCT corrigido para a linha base. 


\subsubsection{Resultados de OCT}

O coeficiente de atenuação óptica total foi determinado a partir da análise do sinal de OCT das amostras, baseando-se no decaimento exponencial desse sinal. Os valores dos coeficientes de atenuação médios de cada amostra foram comparados antes e depois da desmineralização provocada pela ciclagem de $\mathrm{pH}$, exceto para o grupo 0 , que foi examinado uma única vez devido ao fato de não ter sido submetido ao desafio cariogênico. Também foi realizada comparação intergrupos para verificar as diferenças entre períodos distintos de ciclagem de $\mathrm{pH}$.

Foram obtidos valores de coeficiente de atenuação óptica para diferentes profundidades da amostra, conforme apresentado na FIGURA 34.

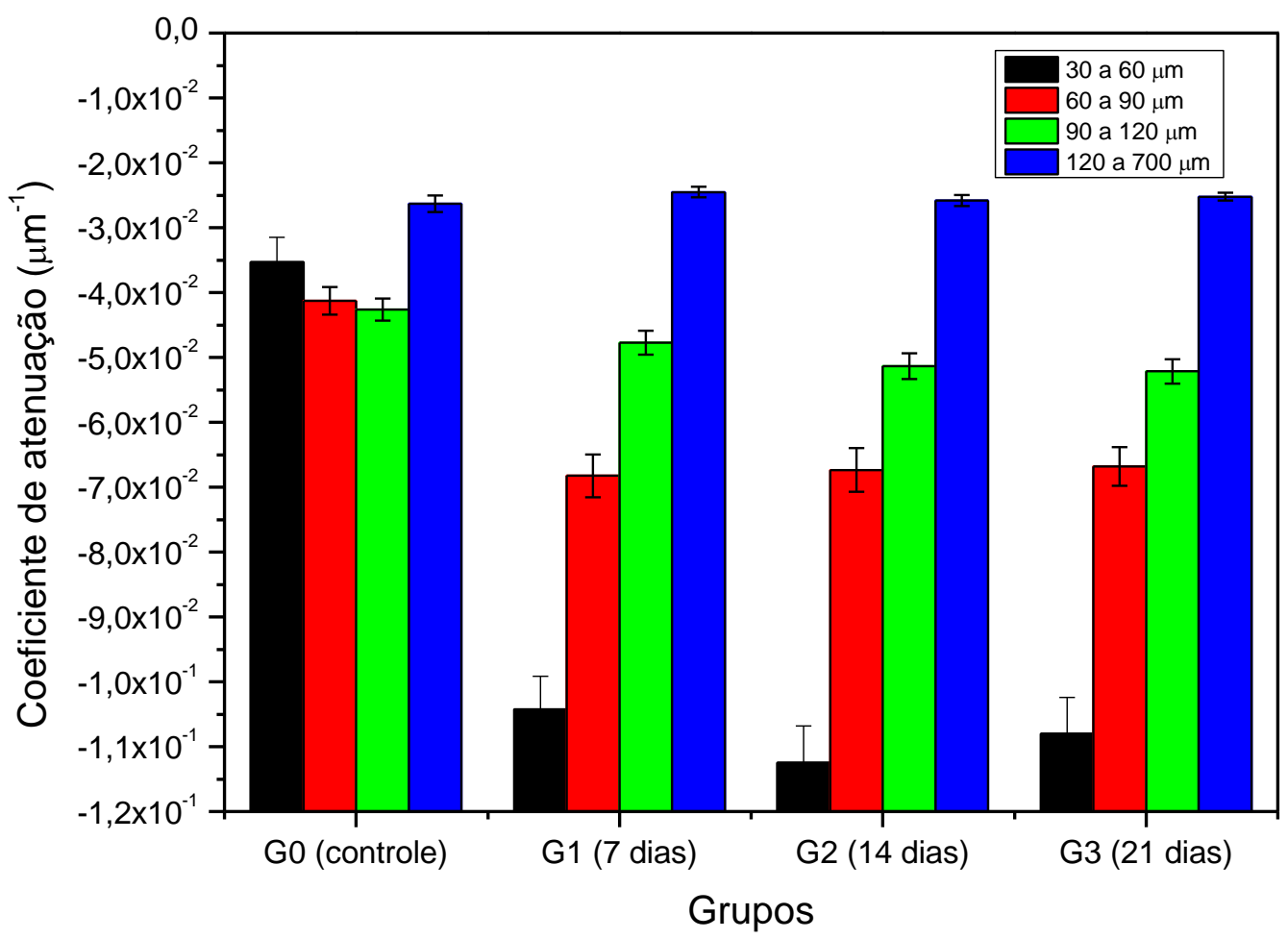

FIGURA 34: Valores do coeficiente de atenuação óptica para diferentes profundidades de análise, para todos os grupos estudados. O sinal negativo dos valores representa 0 decaimento exponencial da amplitude do sinal elétrico da OCT. 
O coeficiente de atenuação óptica total foi maior, em valores absolutos (desconsiderando-se o sinal negativo do decaimento exponencial da intensidade do sinal de OCT) para as regiões mais superficiais em todos os grupos (em preto no gráfico), o que pode ser justificado pelo menor conteúdo mineral nessas regiões. Apesar de não ter sido submetido à simulação de desafio cariogênico, o grupo controle também apresentou maior valor de coeficiente de atenuação para profundidades de análise mais próximas a superfície, em relação ao valor obtido para a profundidade de 120 a $700 \mu \mathrm{m}$, o que pode ser decorrência de processos de desmineralização sofridos por esses dentes anteriores ao início do experimento, visto que os dentes foram obtidos a partir de doação por um Banco de dentes e por isso, são desconhecidos fatores relacionados à desmineralização, como o tempo em que ficaram armazenados em água até a doação e a origem dos mesmos (se inclusos ou não). Foi observada pequena variação entre os valores de coeficiente de atenuação óptica entre os grupos analisados para as profundidades de 120 a $700 \mu \mathrm{m}$, o que indica que a nessa região o esmalte pode ser considerado sadio para todos os grupos. A constância do valor de coeficiente de atenuação nessa região de análise explica a similaridade do comportamento da técnica de OCT em detectar alterações minerais quando comparadas à microdureza, independentemente da profundidade avaliada estar limitada a 120 ou a $700 \mu \mathrm{m}$, conforme observado no experimento piloto, ao compararmos a FIGURA 29 com a FIGURA 31 e a FIGURA 30 com a FIGURA 32.

Os valores médios de coeficiente de atenuação para a profundidade de 40 a $120 \mu \mathrm{m}$ estão demonstrados na FIGURA 35. Os resultados foram avaliados utilizando o t-test para dados pareados e foi observada diferença estatisticamente significante (intervalo de confiança de 95\%), com valores de $\mathrm{p}$ menores que 0,0001 para todos os grupos avaliados. 


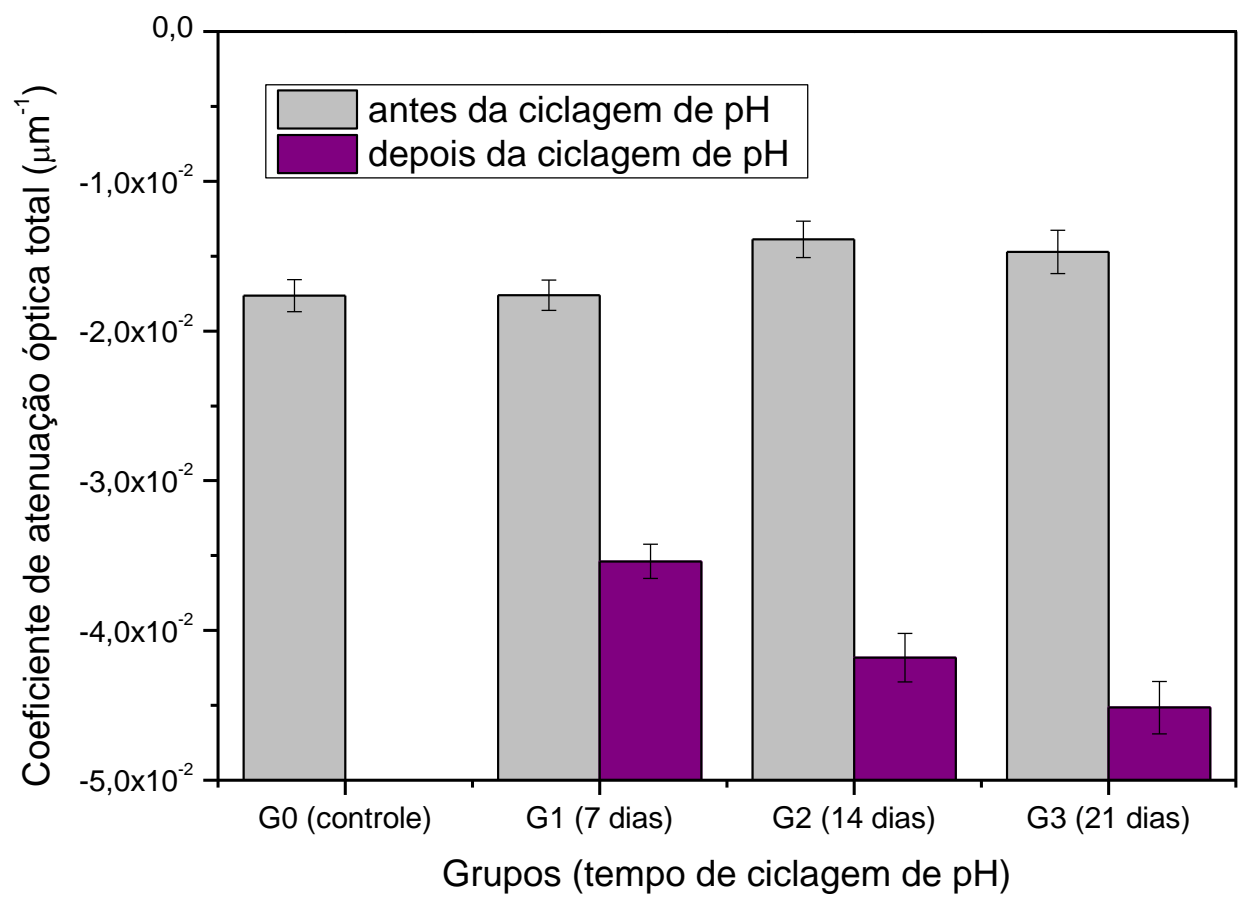

FIGURA 35: Gráfico dos coeficientes de atenuação óptica em função dos grupos antes (controle) e após a desmineralização provocada pela ciclagem de pH. A profundidade avaliada nas amostras foi de 40 a $120 \mu \mathrm{m}$. O sinal negativo das medidas indica o decaimento exponencial da intensidade do sinal de OCT.

O coeficiente de atenuação óptica total foi maior (desconsiderando-se o sinal negativo do decaimento exponencial da intensidade do sinal de OCT) para todas as amostras após a desmineralização, quando comparadas ao esmalte sadio. Isso ocorre porque o processo de desmineralização cria espaços vazios na estrutura do esmalte dental e desse modo, há aumento do número de interfaces, o que aumenta o espalhamento da luz. A desorganização da estrutura prismática do esmalte quando desmineralizado também contribui para o aumento do espalhamento da luz. Assim, quando há maior espalhamento na porção mais superficial da amostra é esperada menor penetração da luz para as camadas mais internas do esmalte, conforme anteriormente na exemplificado na FIGURA 19. Resultados semelhantes foram encontrados por Mujat et al. (2003) ${ }^{50}$ em sua análise de espalhamento da luz em esmalte dental cariado e sadio.

No entanto, devido ao reduzido número de estudos sobre coeficiente de atenuação para análise de desmineralização de esmalte dental, não há 
consenso na literatura sobre o aumento do coeficiente de atenuação óptica total e diminuição da profundidade de penetração da luz nas amostras desmineralizadas quando comparadas ao esmalte sadio. Os resultados apresentados neste estudo e também por Mujat et al. (2003) ${ }^{50}$ são contrários aos encontrados por Popescu et al. $(2008)^{46}$ e Sowa et al. $(2011)^{52}$. Esses autores apresentaram coeficientes de atenuação óptica menores e maior penetração da luz em amostras cariadas. Porém, diferentemente do que foi realizado neste estudo, Popescu et al. $(2008)^{46}$ e Sowa et al. $(2011)^{52}$ utilizaram lesões de mancha branca de cáries naturais em seus trabalhos, o que indica desmineralização mais intensa dessas amostras. Com o aumento da perda mineral, formam-se porosidades maiores, havendo maior probabilidade da luz percorrer o interior desses poros sem que interaja com centros espalhadores. Neste caso é esperado menor espalhamento da luz nas camadas mais superficiais (região desmineralizada) e, consequentemente, maior alcance da luz em profundidade na amostra.

A comparação intergrupos foi realizada utilizando a diferença entre os coeficientes de atenuação óptica obtidas antes e depois da ciclagem de $\mathrm{pH}$. Os resultados estão apresentados na FIGURA 36.

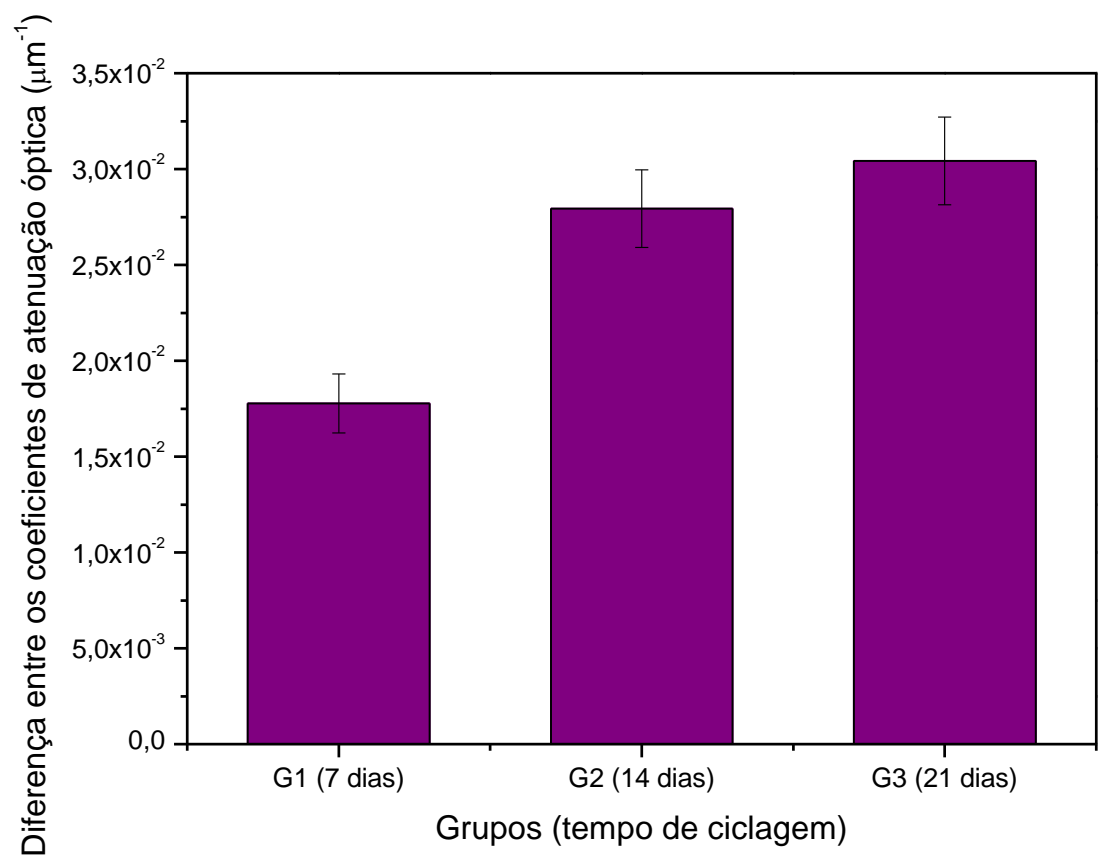

FIGURA 36: Gráfico da diferença entre os coeficientes de atenuação obtidos antes e depois da simulação do desafio cariogênico, para cada um dos grupos avaliados. A profundidade das amostras analisadas foi de 40 a $120 \mu \mathrm{m}$. 
Foi observada tendência de aumento da diferença entre os coeficientes de atenuação em função do tempo de ciclagem de $\mathrm{pH}$ a que foi submetido cada grupo, porém, não foi verificada diferença significante entre os grupos G2 e G3, segundo o teste estatístico Anova-Tukey, o que pode ser observado pelas barras de erro padrão (desvio padrão da média).

Com o objetivo de identificar um limiar de coeficientes de atenuação óptica para esmalte dental sadio (não submetido ao processo de desmineralização), foi avaliada a distribuição dos coeficientes de atenuação de todas as amostras de cada grupo, antes e depois da ciclagem de $\mathrm{pH}$, conforme a FIGURA 37.

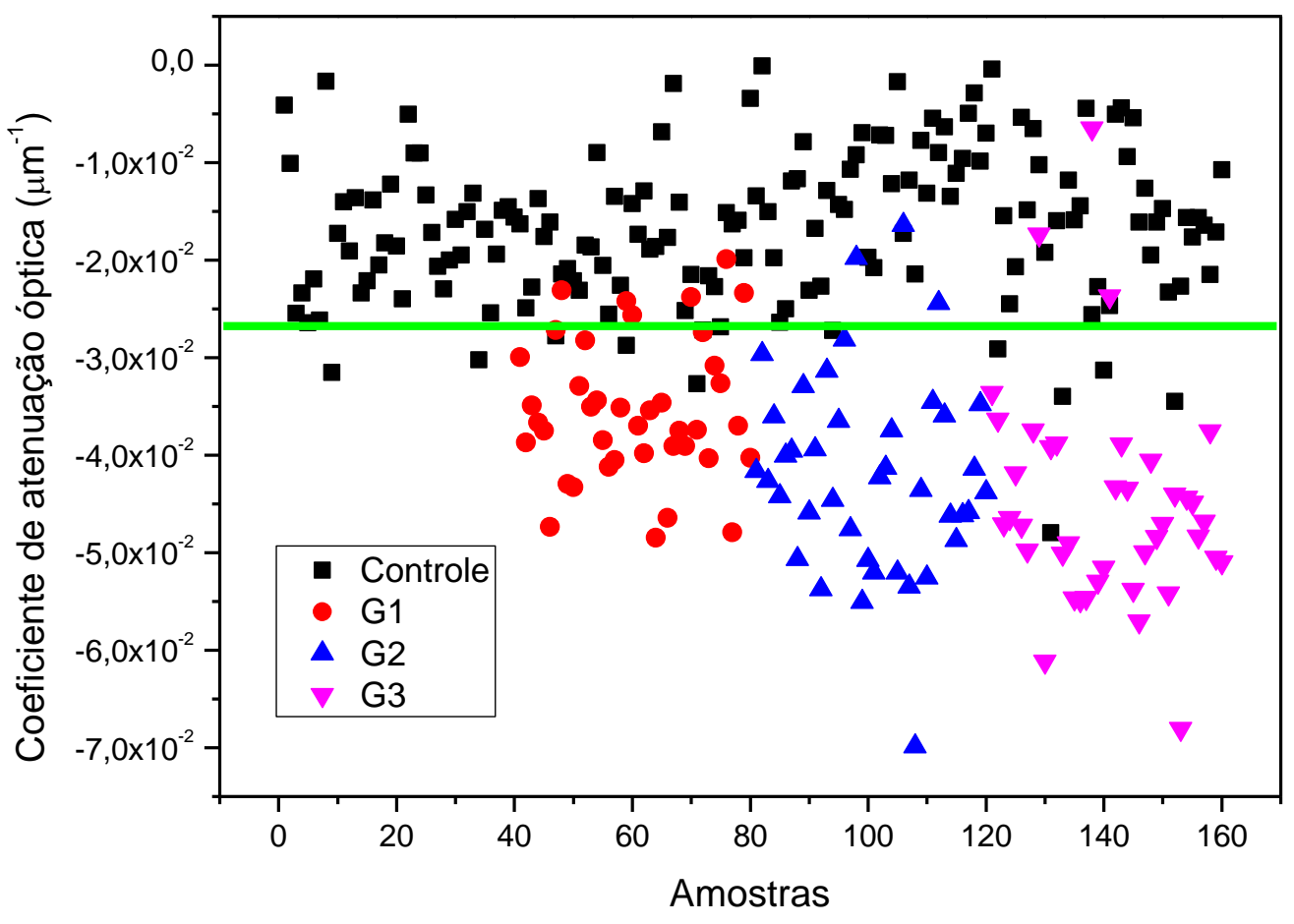

FIGURA 37: Distribuição dos valores de coeficiente de atenuação óptica total, obtidos a partir da análise da profundidade de 40 a $120 \mu \mathrm{m}$. A linha verde representa o valor do limiar de coeficiente de atenuação óptica de 2,67E-2 $\mu \mathrm{m}^{-1}$. O sinal negativo associado aos valores de coeficiente de atenuação óptica refere-se ao decaimento exponencial da intensidade do sinal de OCT. 
A partir da análise dos resultados da figura anterior, o limiar de coeficiente de atenuação encontrado foi de $2,67 \mathrm{E}-2 \mu \mathrm{m}^{-1}$, para que fossem obtidos valores de sensibilidade e especificidade satisfatórios de, respectivamente, 0,9 e 0,92.

Para comparar os grupos, além do coeficiente de atenuação óptica total, também foi analisada a intensidade média do sinal de OCT em função da profundidade, conforme apresentado na FIGURA 38.

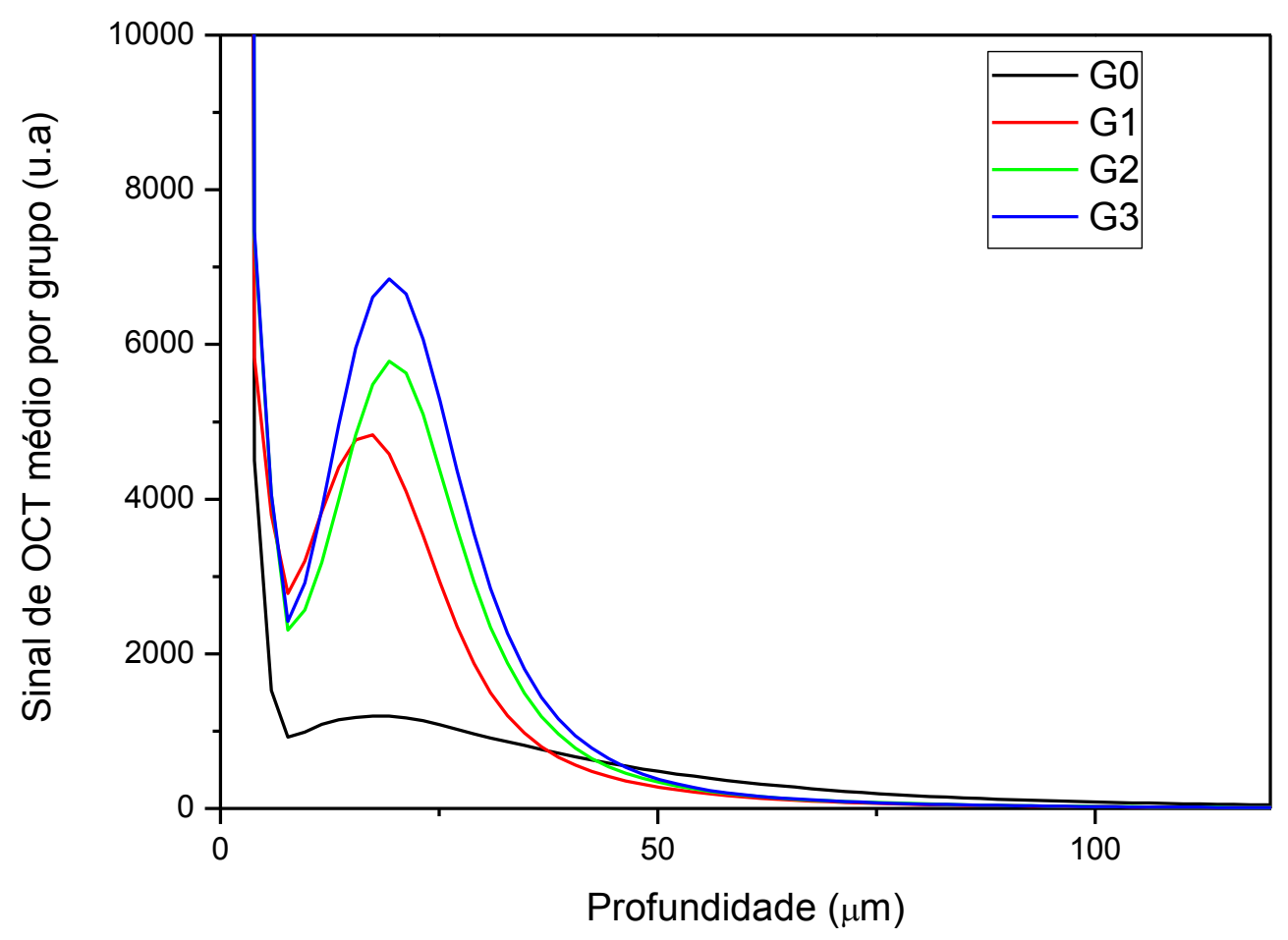

FIGURA 38: Gráfico de intensidade de sinal de OCT em função da profundidade, para cada um dos grupos de análise, após a simulação do desafio cariogênico.

A intensidade do sinal de OCT detectado foi maior quanto maior o período de ciclagem de $\mathrm{pH}$ a que o grupo foi submetido, o que sugere que a intensidade do sinal aumenta com a progressão da perda mineral. Resultados semelhantes foram encontrados por Jones et al. (2006) ${ }^{17}$ utilizando uma variação da técnica de OCT, sensível à polarização..

$\mathrm{Na}$ figura anterior (FIG.38), é possível observar a presença de 2 picos, para todos os grupos analisados. O primeiro está relacionado com a intensa 
refletividade da superfície, que afeta a resolução do sistema de OCT para análise da região subsuperficial ${ }^{17,51}$. A partir do segundo pico, que ocorre aproximadamente a $25 \mu \mathrm{m}$ da superfície para os grupos analisados, é possível obter o coeficiente de atenuação óptica total do sinal de OCT. A diferença de profundidade na qual se observa esse pico comparada ao experimento piloto deve-se ao fato da utilização do índice de refração de 1,6 para o experimento final, enquanto que o experimento piloto teve o índice de refração igual a 1.

A fim de analisar a região mais próxima da superfície do esmalte dental, foram obtidos os coeficientes de atenuação óptica total, para a profundidade de 25 a $120 \mu \mathrm{m}$ de todas as amostras antes e depois da simulação do desafio cariogênico. Os valores médios de coeficiente de atenuação óptica total estão apresentados na FIGURA 39

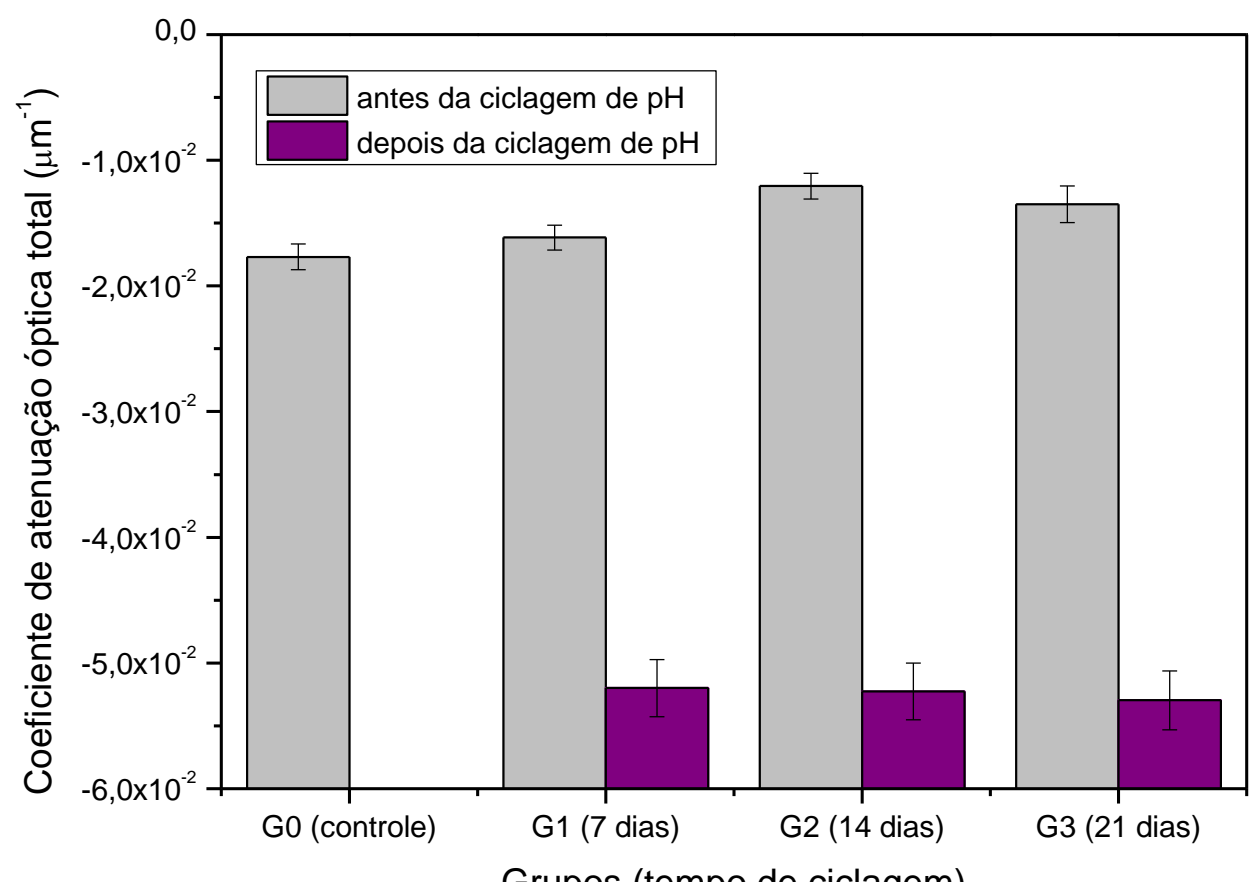

FIGURA 39: Gráfico dos coeficientes de atenuação óptica antes e após a ciclagem de $\mathrm{pH}$, para a profundidade de 25 a $120 \mu \mathrm{m}$. O sinal negativo associado aos valores de coeficiente de atenuação óptica refere-se ao decaimento exponencial da intensidade do sinal de OCT. 
Ao término da simulação do desafio cariogênico, todos os grupos apresentaram diferença estatística com relação ao início do experimento e os valores de $p$ encontrados foram menores que 0,0001.

A comparação intergrupos foi realizada utilizando a diferença entre os coeficientes de atenuação óptica obtidas antes e depois da ciclagem de $\mathrm{pH}$. Os resultados estão apresentados na FIGURA 40.

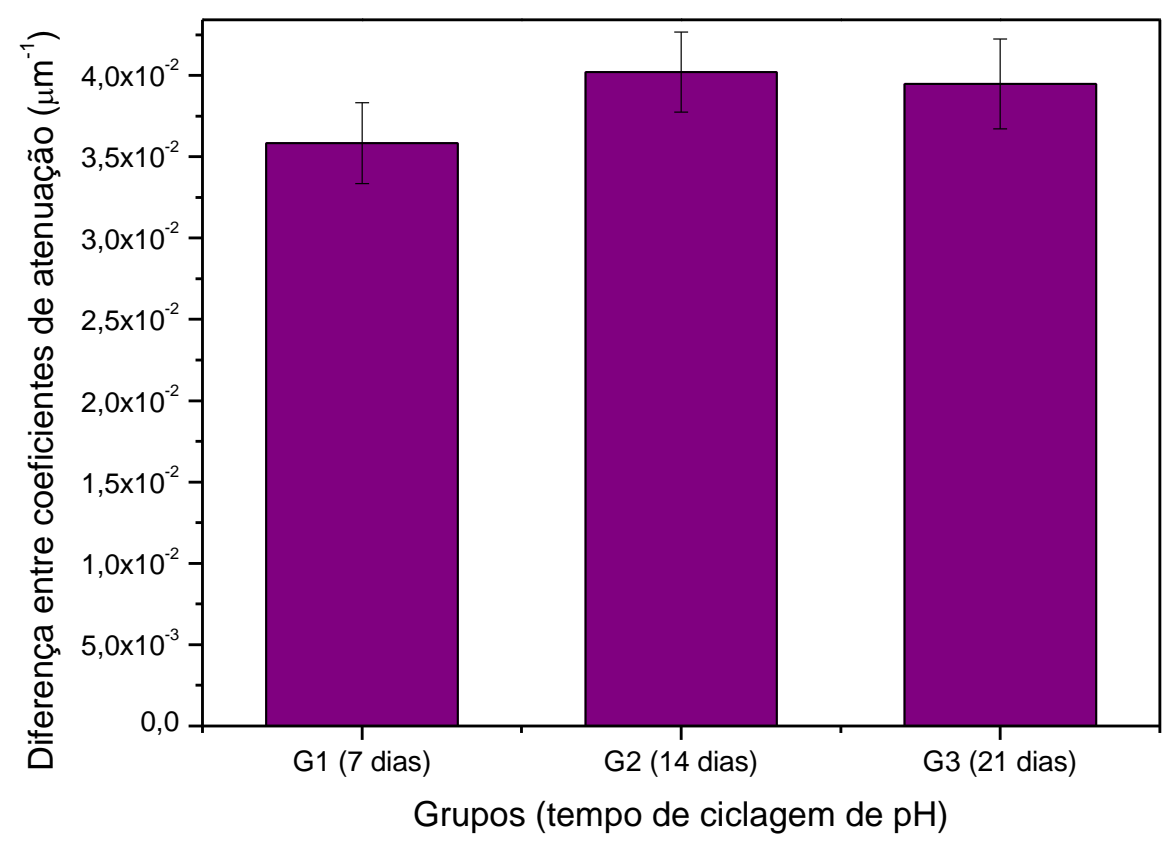

FIGURA 40: Gráfico da diferença entre os coeficientes de atenuação obtidos antes e depois da simulação do desafio cariogênico, para a profundidade de análise de 25 a 120 $\mu \mathrm{m}$.

Não foi observada diferença estatística entre os grupos avaliados, segundo teste Anova-Tukey, considerando a profundidade de análise do sinal de OCT de 25 a $120 \mu \mathrm{m}$. A desmineralização mais intensa que ocorre nas regiões mais próximas à superfície parece exercer forte influência sobre o coeficiente de atenuação óptica total, impossibilitando a detecção de possíveis diferenças entre os grupos submetidos a tempos distintos de ciclagem de $\mathrm{pH}$. A análise de uma região do esmalte dental menos superficial, como a de $40 \mu \mathrm{m}$ a $120 \mu \mathrm{m}$ de profundidade permite verificar diferenças entre os coeficientes de atenuação 
óptica total de acordo com o período de ciclagem de $\mathrm{pH}$, sendo o grupo 1 estatisticamente diferente dos grupos 2 e 3 (FIGURA 36).

A fim de identificar um limiar de coeficiente de atenuação óptica para esmalte dental não submetido ao processo de desmineralização, foram comparados os valores das amostras não submetidas à simulação do desafio cariogênico (amostras do grupo controle e amostras antes da ciclagem de $\mathrm{pH}$ ) e amostras cicladas, compostas por amostras dos grupos 1, 2 e 3. Os resultados estão presentes na FIGURA 41.

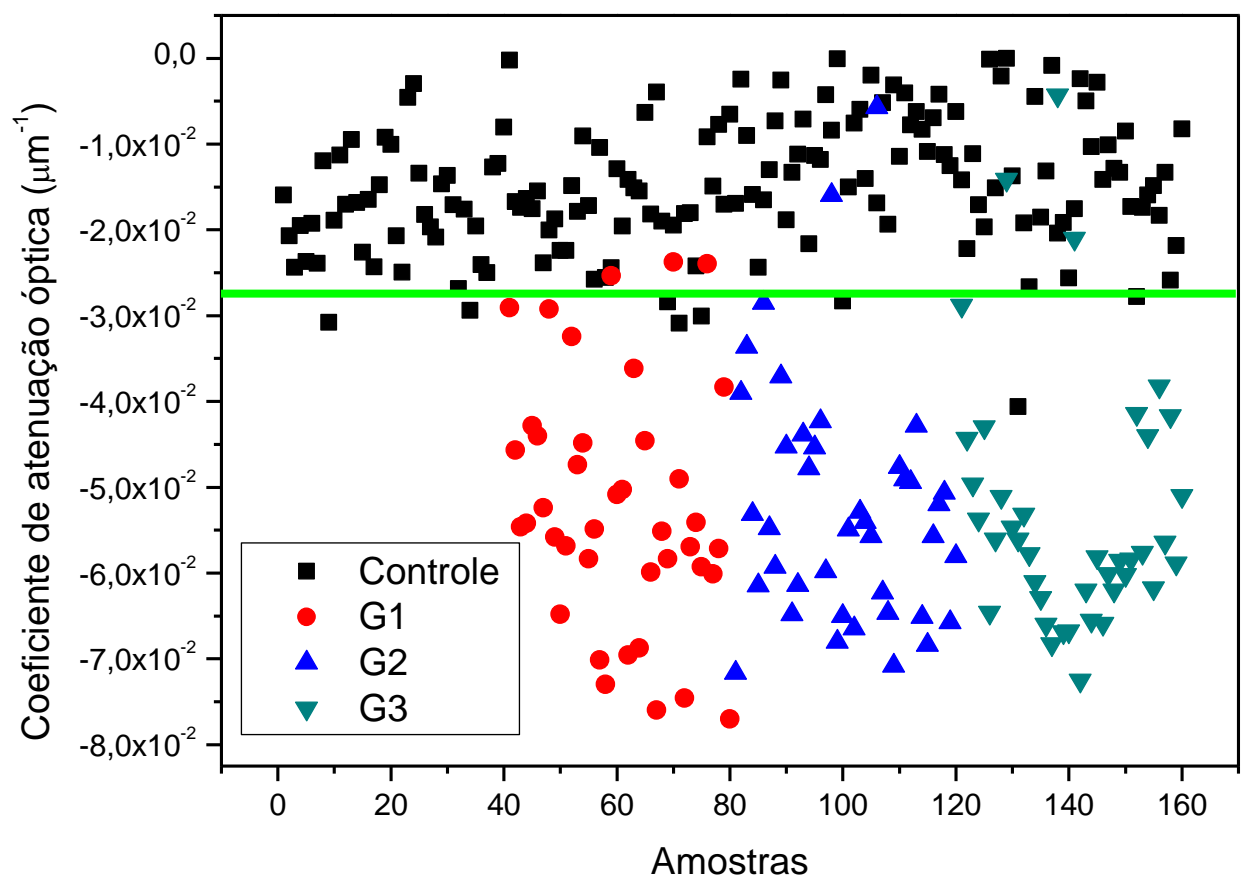

FIGURA 41: Distribuição dos valores de coeficiente de atenuação óptica total, obtidos a partir da análise da profundidade de 25 a $120 \mu \mathrm{m}$. A linha verde representa o valor do limiar de coeficiente de atenuação óptica de 2,74E-2 $\mu \mathrm{m}^{-1}$. O sinal negativo associado aos valores de coeficiente de atenuação óptica refere-se ao decaimento exponencial da intensidade do sinal de OCT.

Os resultados de coeficiente de atenuação óptica para as amostras não submetidas ao desafio cariogênico foram menores, em valores absolutos (desconsiderando-se o sinal negativo do decaimento exponencial), do que os valores obtidos para as amostras após o processo de desmineralização. 
Baseando-se no valor limiar de coeficiente de atenuação óptica total de 2,74E-2 $\mu \mathrm{m}^{-1}$, foram encontrados os valores de sensibilidade e especificidade de, respectivamente, 0,93 e 0,96, o que indica que a análise do coeficiente de atenuação óptica obtido para a profundidade do esmalte dental de 25 a $120 \mu \mathrm{m}$ é adequada para diferenciar as amostras desmineralizadas e as não submetidas à ciclagem de $\mathrm{pH}$.

Além do coeficiente de atenuação, outro parâmetro utilizado para quantificar a diferença entre os sinais de OCT de cada grupo foi a área sob a curva de gráficos de sinal de OCT por profundidade, como utilizado por alguns autores com o termo de refletividade integrada ${ }^{2,17,22}$. Esses autores utilizaram uma variação da técnica de OCT sensível à polarização, que permite o controlar a reflexão da superfície do esmalte e reduzir sua influência sobre as regiões subjacentes. Neste estudo, devido ao sistema de OCT utilizado não ser sensível à polarização, não foram calculadas as áreas totais sob a curva, a exemplo dos trabalhos citados e por esse motivo, os resultados não podem ser comparados. Para evitar a interferência da refletividade da superfície e manter a padronização de profundidade de análise estabelecida nesse estudo, foram calculadas as áreas sob a curva em gráficos de intensidade de sinal de OCT por profundidade, para as regiões de 25 a $120 \mu \mathrm{m}$ e de 40 a $120 \mu \mathrm{m}$, conforme exemplificado na FIGURA 42.

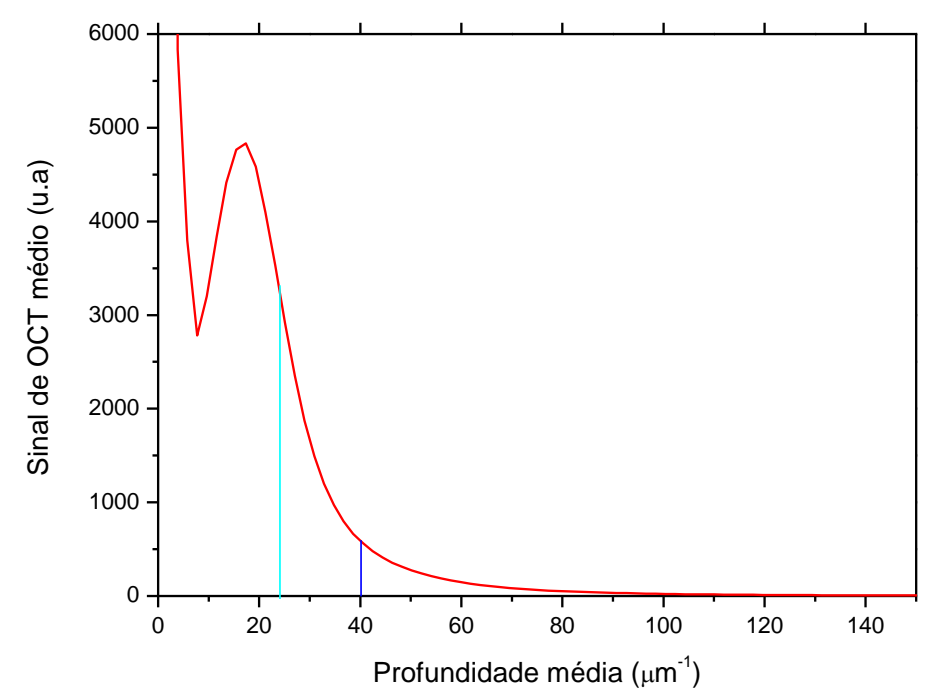

FIGURA 42: Gráfico da intensidade do sinal médio de OCT em função da profundidade para o grupo 1. As regiões demarcadas correspondem às áreas analisadas. 
Os resultados obtidos a partir do cálculo da área sob a curva, para a profundidade de 25 a $120 \mu \mathrm{m}$ estão apresentados na FIGURA 43.

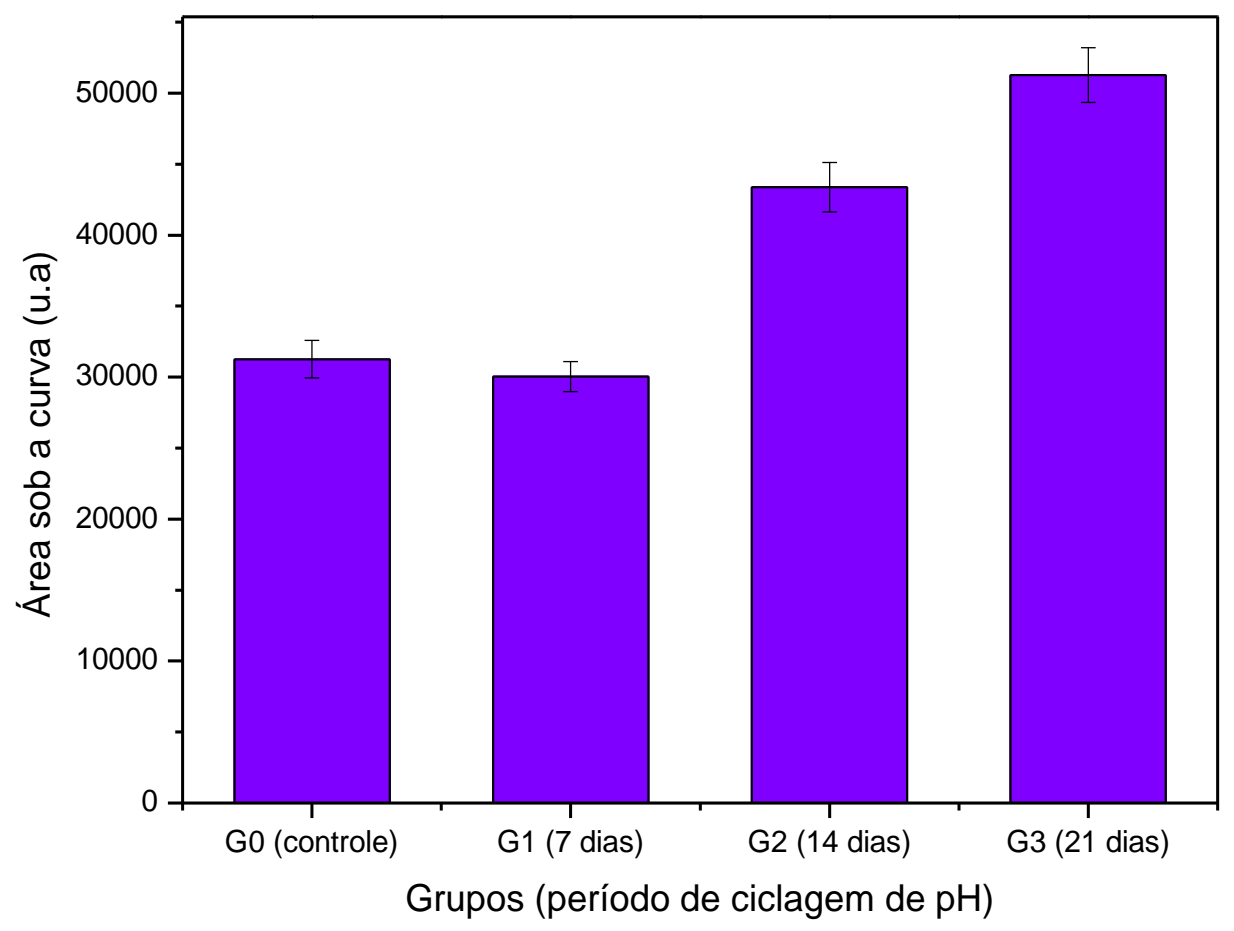

FIGURA 43: Área sob a curva para a profundidade de 25 a $120 \mu \mathrm{m}$, obtida a partir do gráfico de sinal de OCT por profundidade, para cada um dos grupos avaliados.

Na figura anterior é possível observar a tendência de aumento de área de acordo com o tempo de simulação do desafio cariogênico. A comparação intergrupos para perda mineral foi realizada por meio do teste-Z. O grupo controle (G0) foi significantemente diferente $(p<0,0001)$ dos grupos $G 2$ e $G 3$, submetidos, a respectivamente, 14 e 21 dias de ciclagem de pH. Foi encontrada diferença estatística também entre os grupos G1 e G2 e entre G1 e G3, com valores de $p<$ 0,0001 e entre G2 e G3 ( $p=0,0020)$

Foram também avaliadas as áreas sob o gráfico de intensidade de sinal para a profundidade de 40 a $120 \mu \mathrm{m}$, apresentadas na FIGURA 44. 


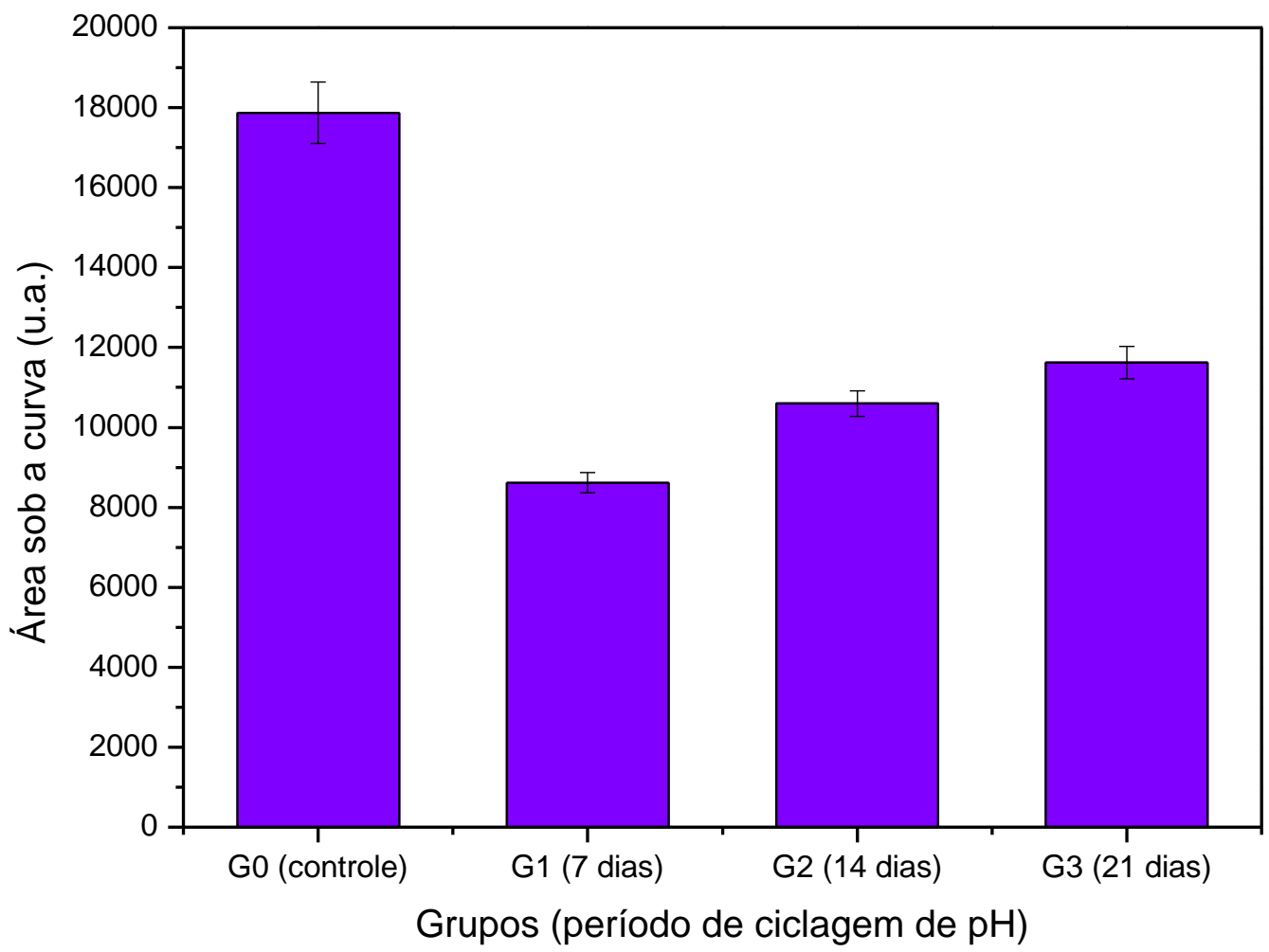

FIGURA 44: Área sob a curva para a profundidade de 40 a $120 \mu \mathrm{m}$, obtida a partir do gráfico de sinal de OCT por profundidade, para cada um dos grupos avaliados.

Foi verificada tendência de aumento das áreas com o aumento do tempo de ciclagem de $\mathrm{pH}$ a que foram submetidos os grupos, assim como observado para a profundidade de 25 a $120 \mu \mathrm{m}$ anteriormente analisada, com exceção do Grupo 0 (controle), que apresentou a maior área devido ao fato do decaimento exponencial da intensidade do sinal ser menos acentuado para esse grupo, o que se torna mais evidente para as regiões menos superficiais, conforme apresentado anteriormente na FIGURA 38. Os grupos foram analisados utilizando o teste estatístico $Z$ e foram encontrados valores de $p$ menores que 0,0001 para todas as comparações realizadas, exceto para a comparação entre os grupos 2 e 3 , cujo valor de $p$ encontrado foi de 0,0471 .

\subsubsection{Resultados de Microdureza seccional}

Os valores de microdureza seccional Knoop foram tabulados em função da profundidade, conforme realizado no experimento piloto. Foram 
calculadas médias de valores de microdureza para uma das fatias obtidas de cada amostra. Os resultados foram expressos em gráficos de valores de microdureza em função da profundidade, conforme apresentado anteriormente na FIGURA 22 da Seção 5.1.2.

Foram calculados os valores médios de microdureza em função da profundidade para cada um dos grupos. Os resultados estão apresentados na FIGURA 45.

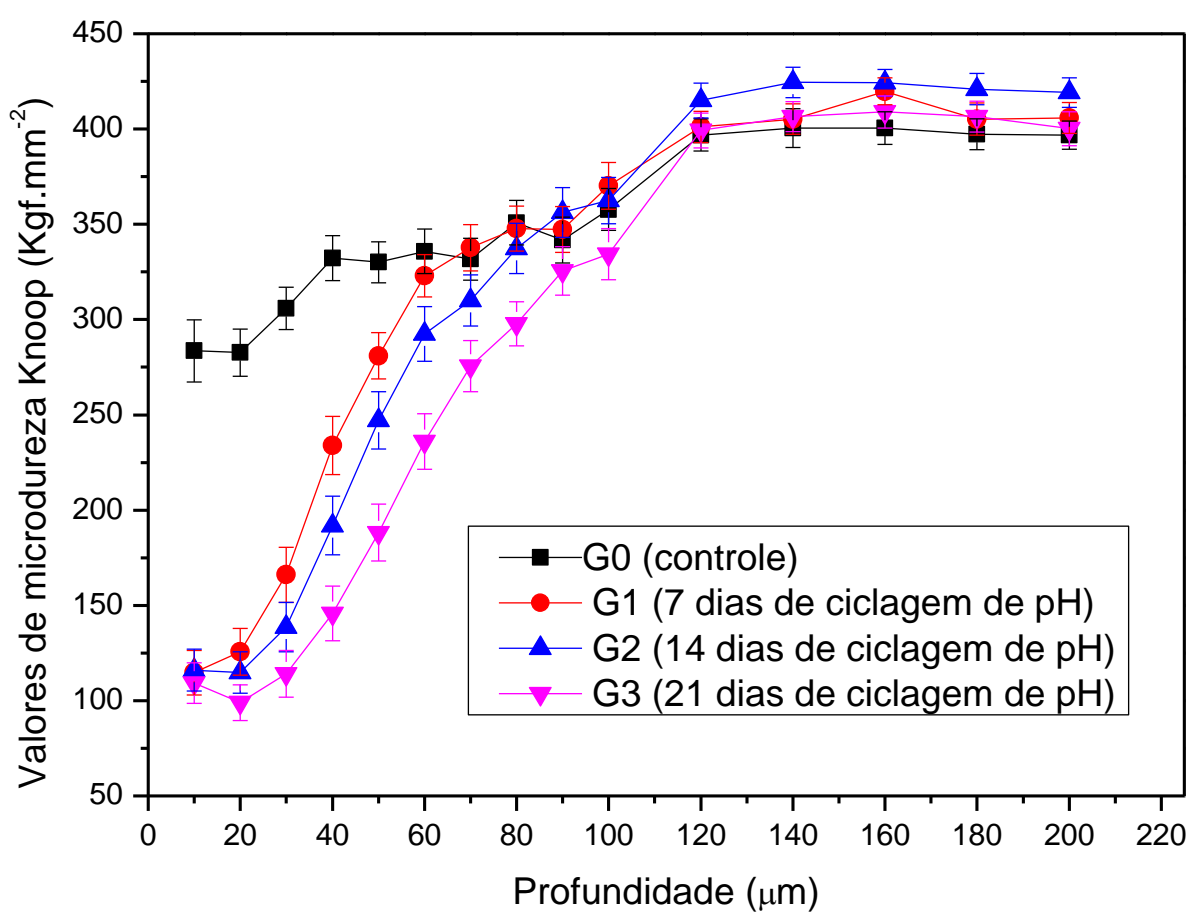

FIGURA 45: Gráfico dos valores médios de microdureza em função da profundidade para os grupos de análise. Maior variação dos valores de microdureza é observada até a profundidade de $120 \mu \mathrm{m}$.

$\mathrm{Na}$ figura anterior é possível observar que os valores de microdureza seccional aumentam com a profundidade até aproximadamente $120 \mu \mathrm{m}$ e, a partir desta, sofrem pouca variação, assim como verificado no experimento piloto. Os valores de microdureza encontrados apresentam relação inversa com o tempo de ciclagem de $\mathrm{pH}$ a que foram submetidos os grupos. Assim, considerando-se os resultados até a profundidade de $120 \mu \mathrm{m}$, o maior valor de microdureza foi obtido para o grupo controle e o menor resultado foi apresentado pelo grupo 3 (21 dias de ciclagem de $\mathrm{pH}$ ), o que indica que o modelo utilizado para simulação de 
desafio cariogênico foi capaz de produzir perdas minerais gradativas ao longo do tempo.

Para comparar a desmineralização em diferentes tempos de ciclagem foram considerados os valores de microdureza obtidos para a profundidade de 20 a $120 \mu \mathrm{m}$ e 40 a $120 \mu \mathrm{m}$, para que fossem analisadas, aproximadamente, as mesmas regiões avaliadas pela técnica de OCT. Os valores médios de microdureza para as profundidades consideradas estão representados na FIGURA 46.

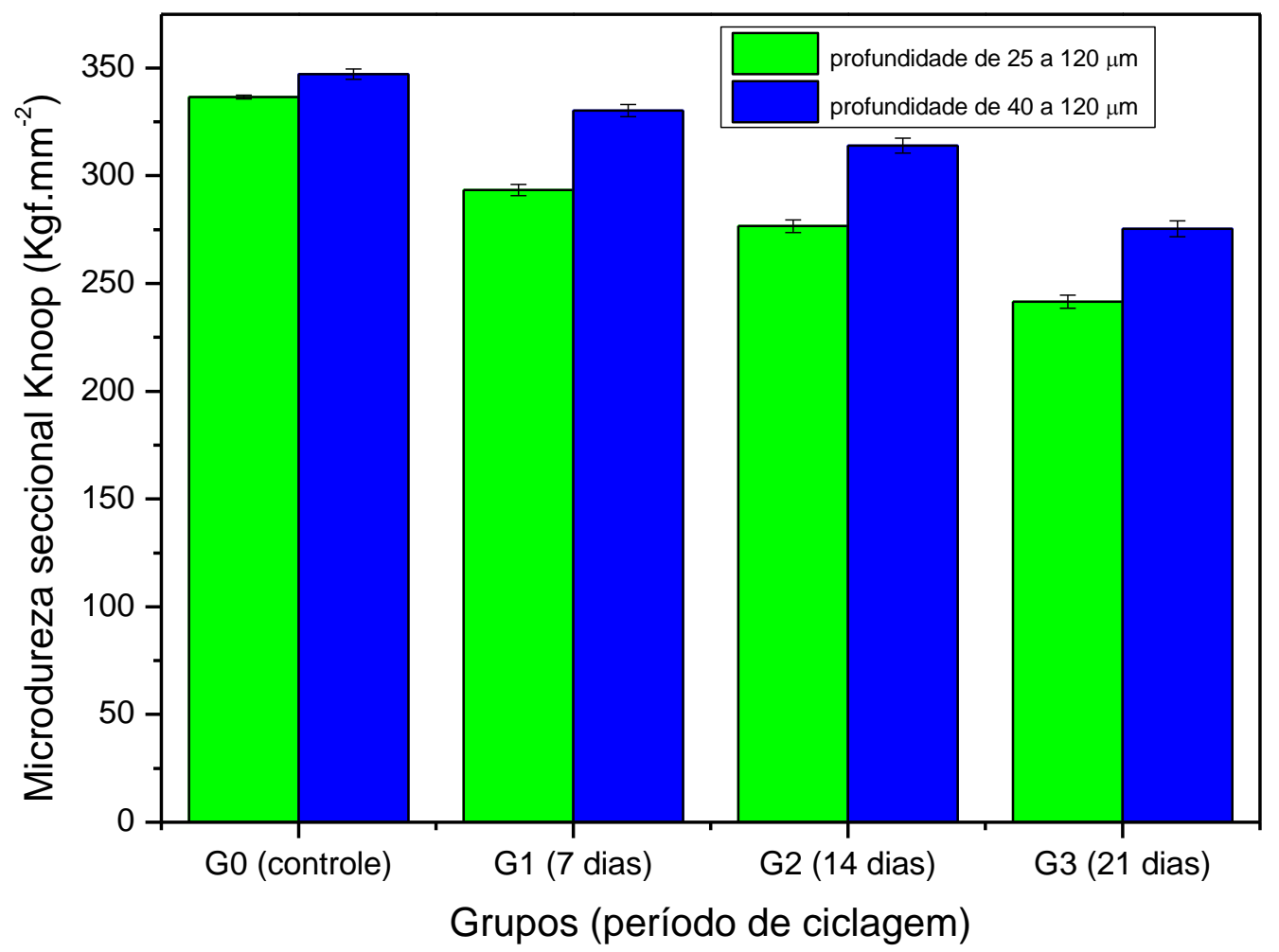

Figura 46: Média de valores de microdureza seccional de cada grupo, para profundidades de 25 a $120 \mu \mathrm{m}$ e 40 a $120 \mu \mathrm{m}$.

Verificou-se redução dos valores médios de microdureza para as profundidades em função do tempo de ciclagem de $\mathrm{pH}$. Os resultados acima foram analisados utilizando o teste estatístico Anova-Tukey, sendo observada diferença significante para todas as comparações intergrupos. Entretanto os valores médios não consideram as alterações ocorridas em cada região do 
esmalte dental. Assim, as possíveis diferenças de conteúdo mineral, entre os grupos foram analisadas também através da área obtida a partir dos gráficos de microdureza em função da profundidade. Para manter a padronização da profundidade de análise, as avaliações foram limitadas entre as profundidades de 20 a $120 \mu \mathrm{m}$ e 40 a $120 \mu \mathrm{m}$, conforme apresentado na FIGURA 47.

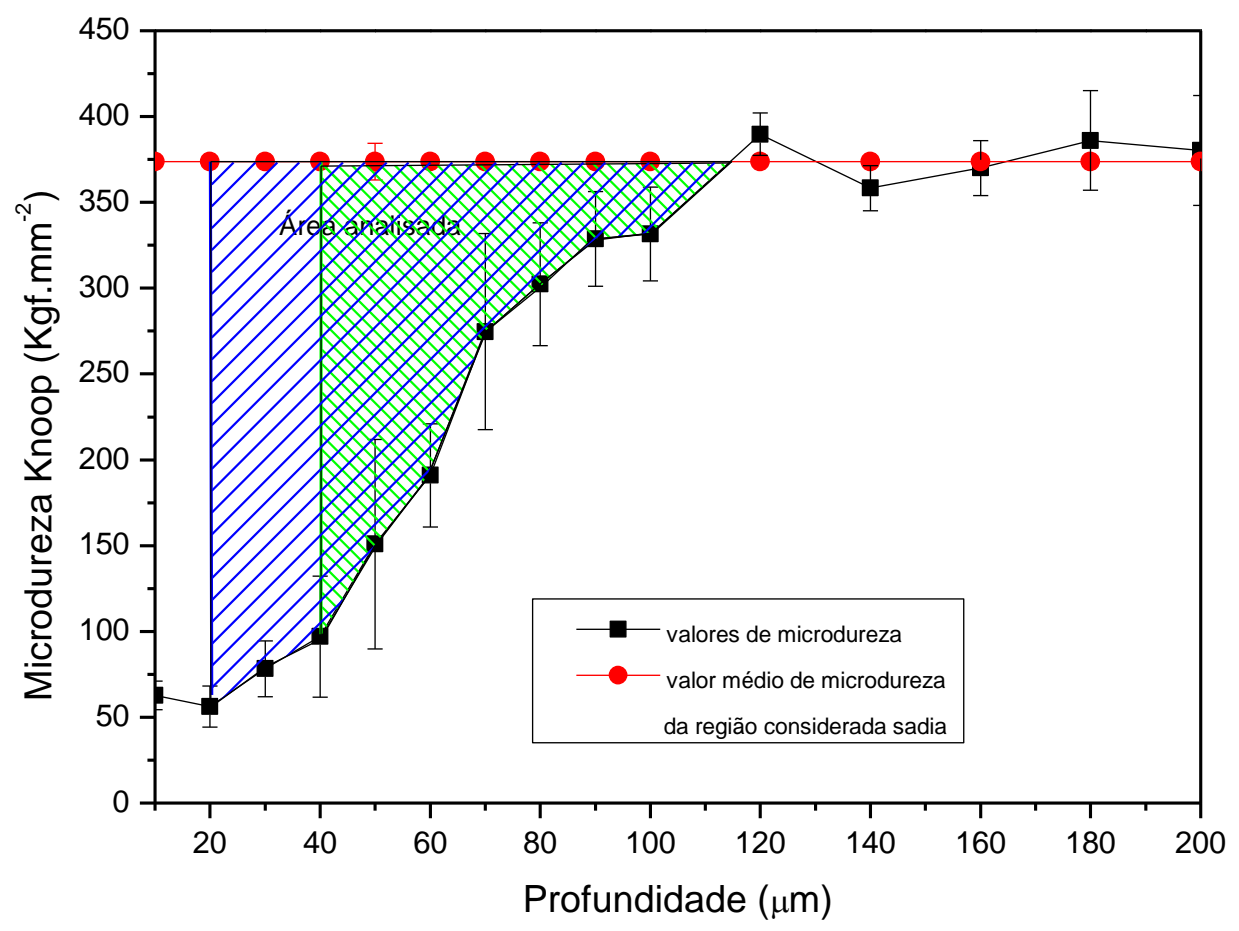

FIGURA 47: Valores de microdureza em função da profundidade para amostra 2 do grupo 3. A área contida entre a linha vermelha (valor médio de microdureza da região saudável) e a linha preta (valores de microdureza para regiões desmineralizadas) representa o conteúdo mineral perdido pela amostra após desafio cariogênico, para as profundidades de 20 a $120 \mu \mathrm{m}$ (hachurado em verde) de 40 a $120 \mu \mathrm{m}$ (azul).

As áreas que representam as alterações de conteúdo mineral de cada grupo ( $\Delta$ Área - Microdureza) foram comparadas para avaliar se houve desmineralização em diferentes estágios através do modelo de simulação de cáries adotado. Por não ter sido submetido à ciclagem de pH, o grupo controle (G0) não foi considerado para essa análise. Os resultados estão apresentados na FIGURA 48. 


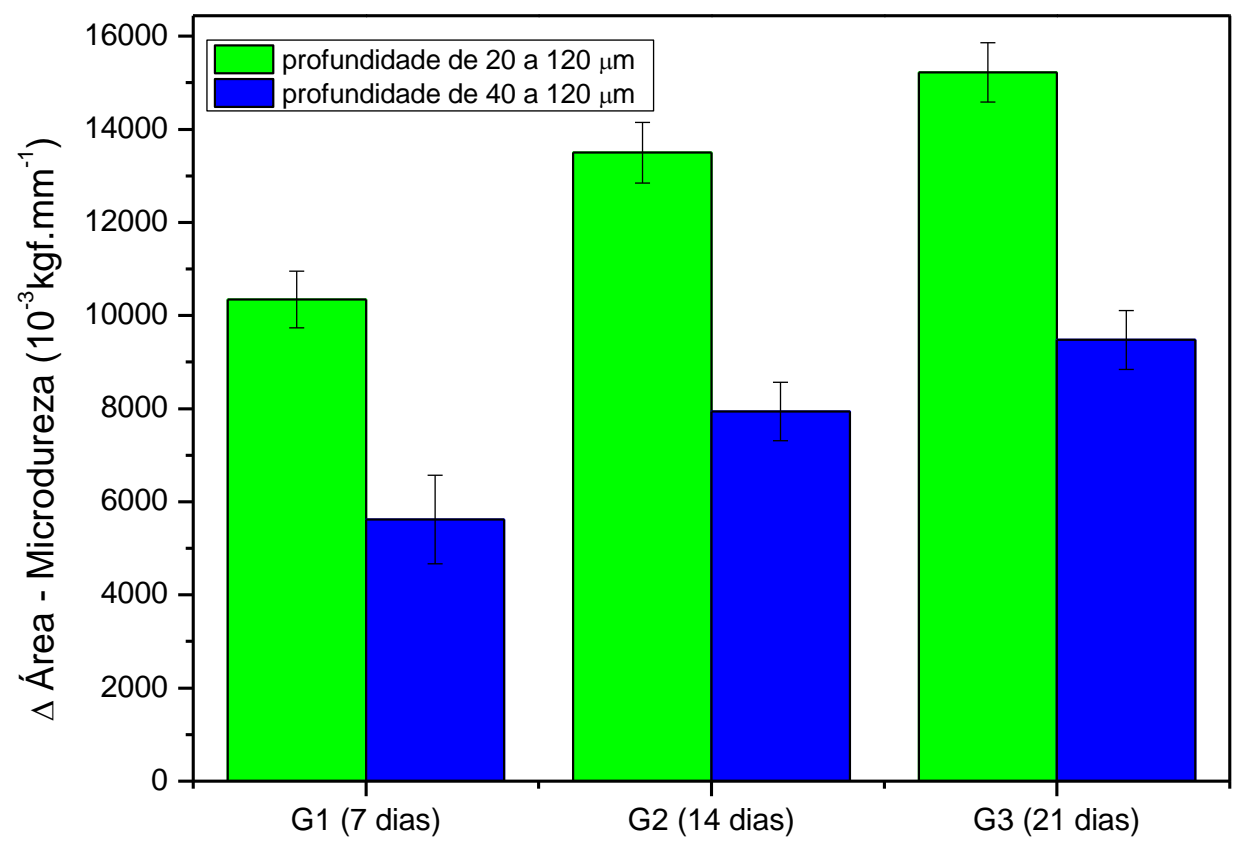

Grupos (período de ciclagem de $\mathrm{pH}$ )

FIGURA 48: Valores de área relacionada à perda mineral obtidos pela diferença de áreas sob a curva da região sadia e desmineralizada em gráficos de microdureza por profundidade, para cada grupo. Maior valor de área relativa à perda mineral é observada no grupo 3 , submetido ao maior tempo de ciclagem de $\mathrm{pH}$.

Na figura acima é possível observar aumento da área relativa à perda mineral, com o aumento do tempo de ciclagem de $\mathrm{pH}$ a que foram submetidos os grupos. Considerando os resultados obtidos a partir da análise da profundidade de 20 a $120 \mu \mathrm{m}$, foi encontrada diferença estatística entre os grupos 1 e 2 $(p=0,0003)$ e entre 1 e 3 ( $p<0,0001)$, o que indica diferentes graus de perda mineral entre esses grupos. Resultados semelhantes foram verificados para a profundidade de 40 a $120 \mu \mathrm{m}$ e os valores de p encontrados entre os grupos G1 e G2 e entre G1 e G3 foram, respectivamente, 0,0400 e 0,0007.

\subsubsection{Comparação entre os resultados de OCT e Microdureza seccional}

Para comparação entre as técnicas de OCT e microdureza seccional foram utilizados as médias de coeficiente de atenuação e de microdureza apresentadas pelos grupos ao término do período de ciclagem de $\mathrm{pH}$, como 
demonstrado na FIGURA 49, para a profundidade de análise de 40 a $120 \mu \mathrm{m}$ em esmalte dental.

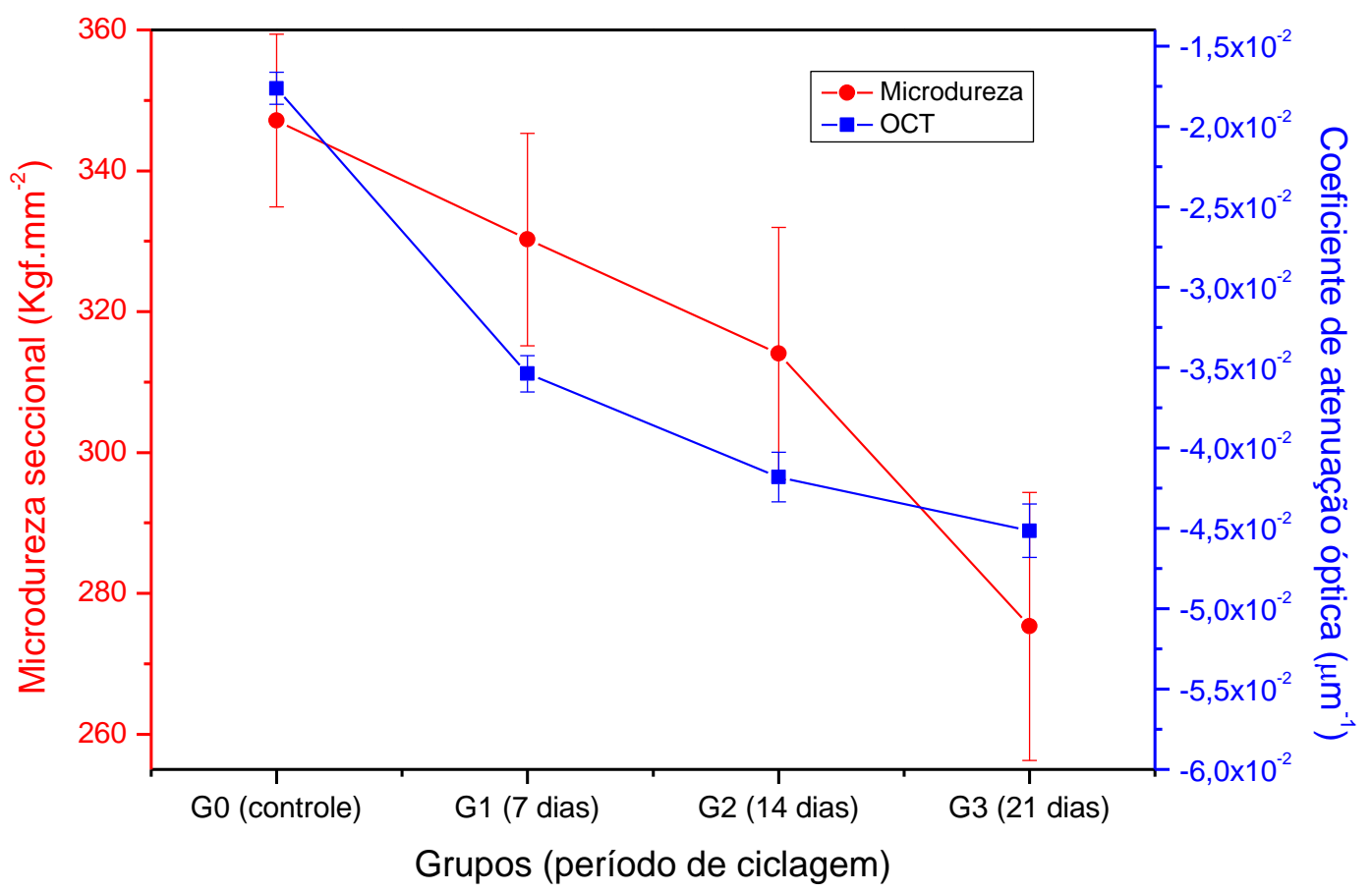

FIGURA 49: Resultados médios de microdureza e de coeficiente de atenuação óptica para a profundidade de 40 a $120 \mu \mathrm{m}$. O sinal negativo associado aos valores de coeficiente de atenuação óptica refere-se ao decaimento exponencial da intensidade do sinal de OCT.

Os valores médios de coeficiente de atenuação óptica aumentaram (desconsiderando-se o sinal negativo relacionado ao decaimento exponencial da intensidade do sinal em função da profundidade) enquanto que os valores de microdureza seccional diminuíram com o aumento do tempo de simulação do desafio cariogênico a que os grupos foram submetidos, apesar de não apresentarem relação de proporcionalidade. Resultados semelhantes foram encontrados ao comparar as médias de microdureza seccional e de coeficiente de atenuação óptica total para a profundidade de 20 a $120 \mu \mathrm{m}$, como apresentado na FIGURA 50. 


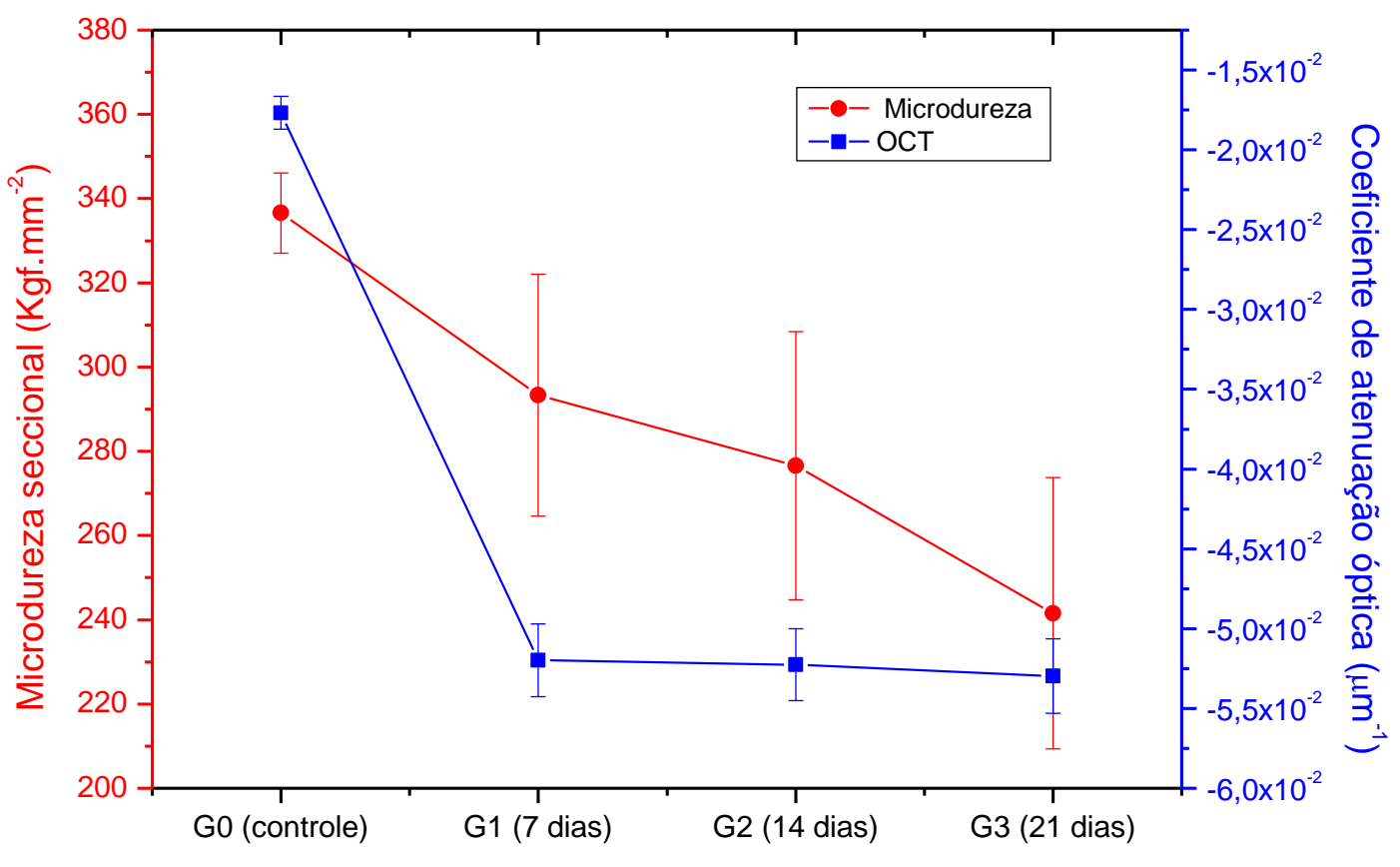

Grupos (período de ciclagem de $\mathrm{pH}$ )

FIGURA 50: Resultados médios de microdureza e de coeficiente de atenuação óptica para a profundidade de 25 a $120 \mu \mathrm{m}$. O sinal negativo associado aos valores de coeficiente de atenuação óptica refere-se ao decaimento exponencial da intensidade do sinal de OCT.

A análise dos gráficos das FIGURAS 49 e 50 indicam que a técnica de OCT apresenta acentuada alteração de coeficiente de atenuação dos grupos submetidos à simulação de desafio cariogênico (independente do período de duração da ciclagem de $\mathrm{pH}$ ), quando comparados ao grupo controle, o que dificulta a correlação direta dos valores médios de coeficiente de correlação e de microdureza Knoop. Além disso, a utilização de valores médios de microdureza não considera a variação dos valores de microdureza com o aumento da profundidade. Para considerar essa variação, a análise mais adequada é o cálculo da diferença de áreas sob a curva entre a região saudável e desmineralizada de gráficos de microdureza seccional em função da profundidade.

As diferenças entre os coeficientes de atenuação óptica, obtidos antes e depois do desafio cariogênico simulado, foram comparadas às áreas 
relacionadas à perda mineral, obtidas por meio da técnica de microdureza seccional. Os resultados dessa análise estão apresentados na FIGURA 51.

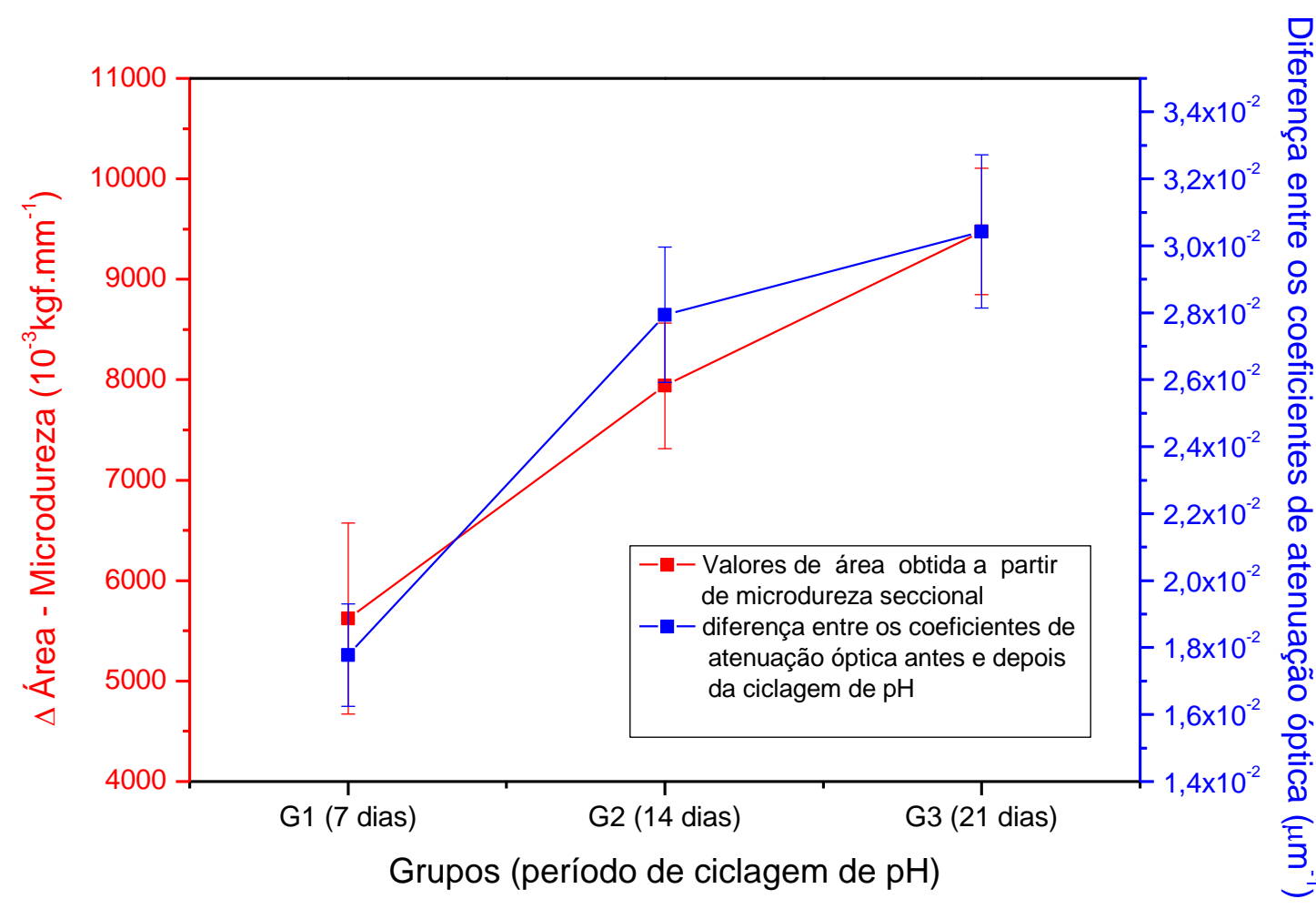

FIGURA 51: Comparação entre os resultados provenientes de testes de microdureza seccional e de OCT, para avaliação de alteração do conteúdo mineral, para a profundidade de análise de 40 a $120 \mu \mathrm{m}$ em esmalte dental.

Na figura acima é possível observar que as técnicas empregadas no estudo para avaliação de desmineralização em esmalte dental apresentam a mesma tendência de crescimento em função do tempo de ciclagem de $\mathrm{pH}$ a que foram submetidos os grupos. Para avaliar a concordância entre as técnicas para detecção de desmineralização, foi calculado o coeficiente de correlação de Pearson, conforme apresentado na Seção 5.1.3. Foi encontrado valor de $\rho$ de 0,97, o que indica forte correlação entre as técnicas analisadas.

A comparação entre área relacionada à perda mineral dos gráficos de microdureza seccional por profundidade e diferença de coeficiente de atenuação óptica total também foi realizada para os resultados obtidos através da avaliação 
da profundidade de aproximadamente 20 a $120 \mu \mathrm{m}$ em esmalte dental, como demonstrado na FIGURA 52.

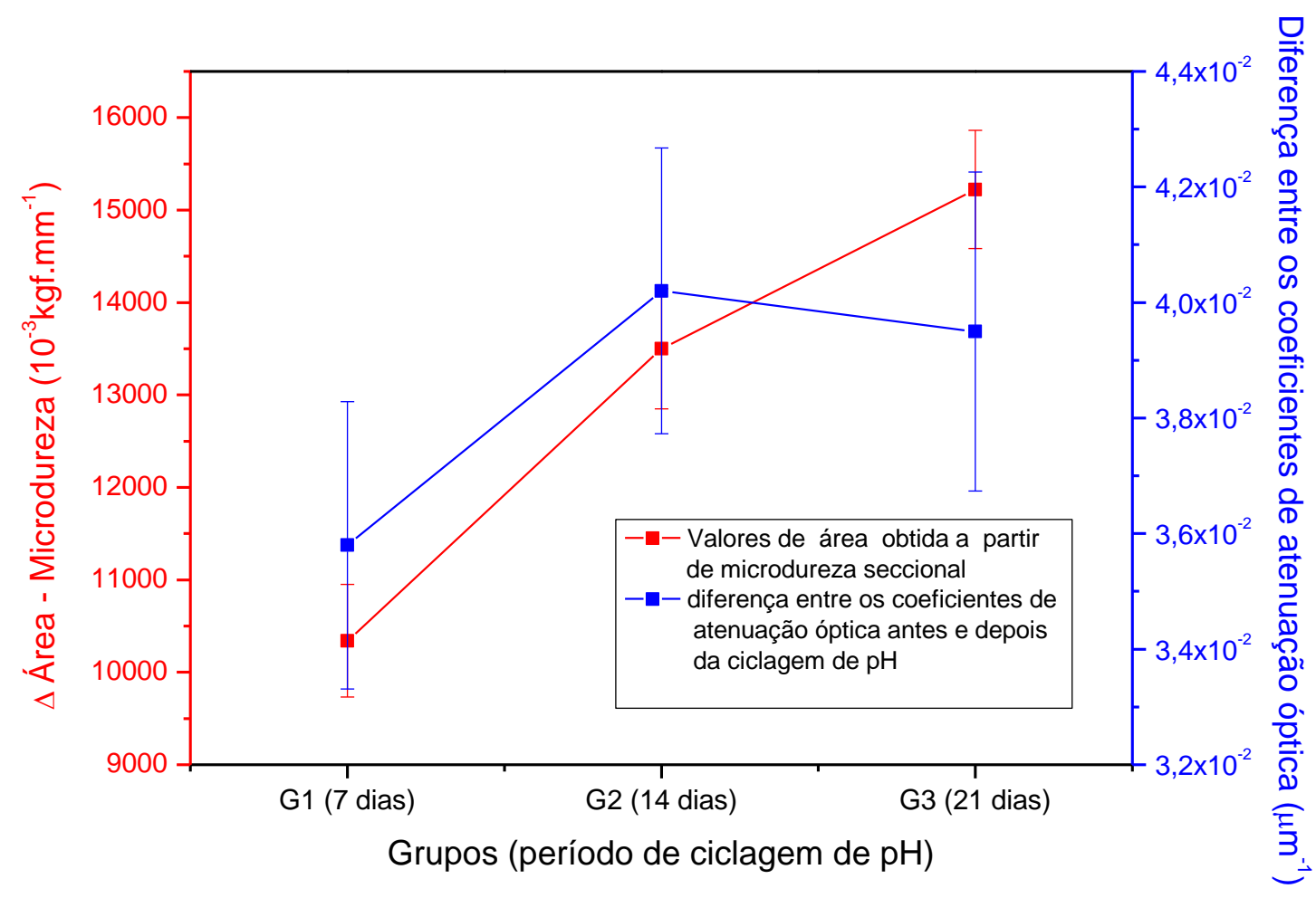

FIGURA 52: Comparação entre os resultados provenientes de testes de microdureza seccional e de OCT, para avaliação de alteração do conteúdo mineral, para a profundidade de análise de $20 \mu \mathrm{m}$ (para microdureza) ou $25 \mu \mathrm{m}$ (para OCT) a $120 \mu \mathrm{m}$ em esmalte dental.

Foi encontrado valor de coeficiente de correlação de Pearson de 0,83, que apesar de indicar elevada correlação entre as técnicas de microdureza e OCT, é menor que o valor encontrado quando considerada, para análise, a profundidade de 40 a $120 \mu \mathrm{m}$ em esmalte dental $(\rho=0,97)$, o que indica ser essa a profundidade mais adequada para análise das técnicas através da comparação da área obtida a partir de gráficos de microdureza e diferença de coeficiente de atenuação óptica total.

Para avaliar a concordância entre as técnicas em detectar alterações minerais, também foram comparadas as áreas obtidas a partir dos gráficos de microdureza e de intensidade de sinal de OCT, ambos, em função da 
profundidade. O grupo controle foi desconsiderado para essa avaliação, por não ter sido submetido à simulação de desafio cariogênico e, portanto, não deve apresentar alteração de conteúdo mineral. As áreas relacionadas à perda mineral de gráficos de microdureza e as áreas sob a curva de gráficos de OCT, considerando a profundidade aproximada de 20 a $120 \mu \mathrm{m}$, estão apresentadas na FIGURA 53.

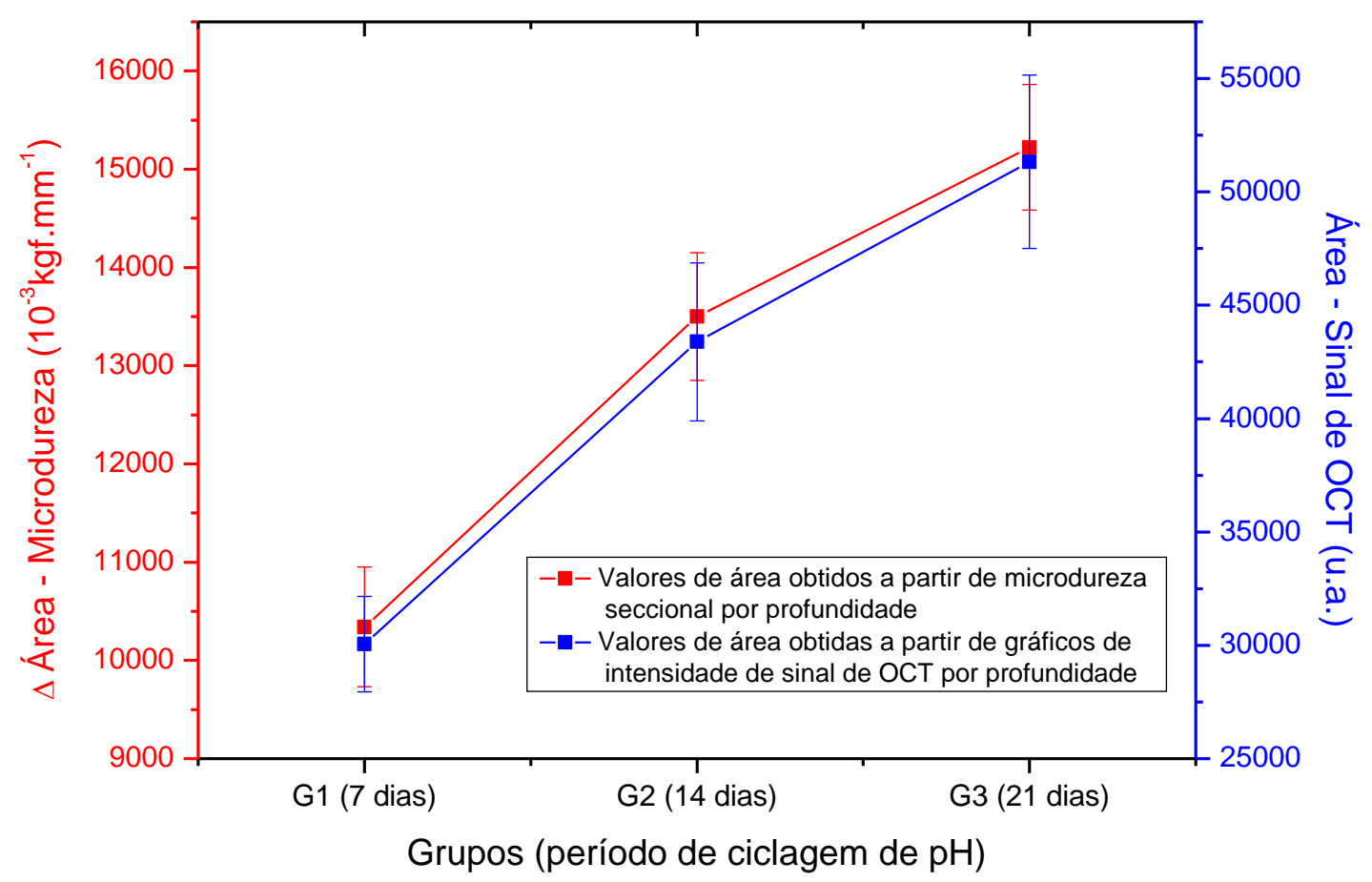

FIGURA 53: Comparação entre as áreas, obtidas, respectivamente, a partir de gráficos de microdureza e de intensidade do sinal de OCT, ambos em função da profundidade, em relação ao tempo de ciclagem de $\mathrm{pH}$ de cada grupo. As áreas comparadas referemse à profundidade de 20 a $120 \mu \mathrm{m}$ para microdureza e de 25 a $120 \mu \mathrm{m}$ para OCT. As barras de erro representam o erro padrão.

Foi encontrada similaridade entre as técnicas analisadas para detecção de alterações de conteúdo mineral do esmalte dental. O coeficiente de correlação encontrado foi de 0,99 , o que indica elevado grau de concordância entre os resultados obtidos a partir das técnicas empregadas. A mesma análise de áreas foi realizada para a profundidade de 40 a $120 \mu \mathrm{m}$, como demonstrado na FIGURA 54. 


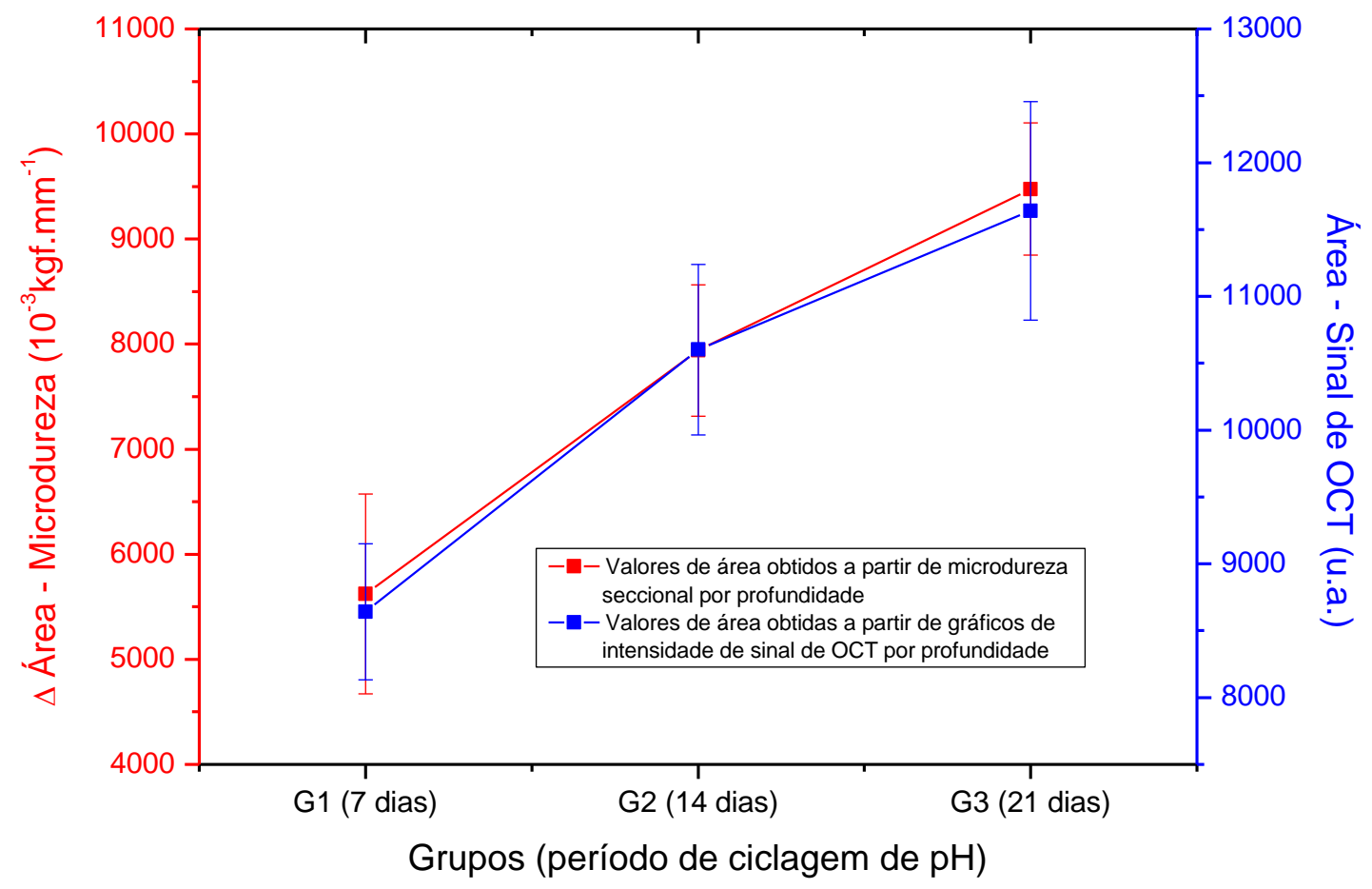

FIGURA 54: Comparação entre as áreas obtidas a partir de gráficos de microdureza e de intensidade do sinal de OCT, ambos em função da profundidade, em relação ao tempo de ciclagem de $\mathrm{pH}$ de cada grupo. As áreas comparadas referem-se à profundidade de 40 a $120 \mu \mathrm{m}$ para microdureza e OCT. As barras de erro representam o erro padrão.

A análise dos resultados acima indica elevada correlação entre as técnicas de OCT e microdureza para avaliação de alteração mineral, com valor de coeficiente de correlação de Pearson de 0,99. Além disso, a diferença entre a desmineralização verificada pelas áreas de microdureza entre os grupos 1 e 2 e entre 2 e 3, também pode ser observada através da técnica de OCT, para as duas profundidades de estudo consideradas.

Para verificar a relação estabelecida entre as técnicas avaliadas, os resultados de área sob a curva de gráficos de OCT por profundidade foram colocados em função dos resultados de diferença de áreas sob a curva entre as regiões desmineralizadas e sadias de gráficos de microdureza (representativas de alteração de conteúdo mineral), para as duas profundidades de análise consideradas no estudo $(20 / 25 \mu \mathrm{m}$ a $120 \mu \mathrm{m}$ e $40 \mu \mathrm{m}$ a $120 \mu \mathrm{m})$. Os resultados 
de OCT para a profundidade de 25 a $120 \mu \mathrm{m}$ e de microdureza de $20 \mu \mathrm{m}$ a 120 $\mu \mathrm{m}$ estão apresentados na FIGURA 55.

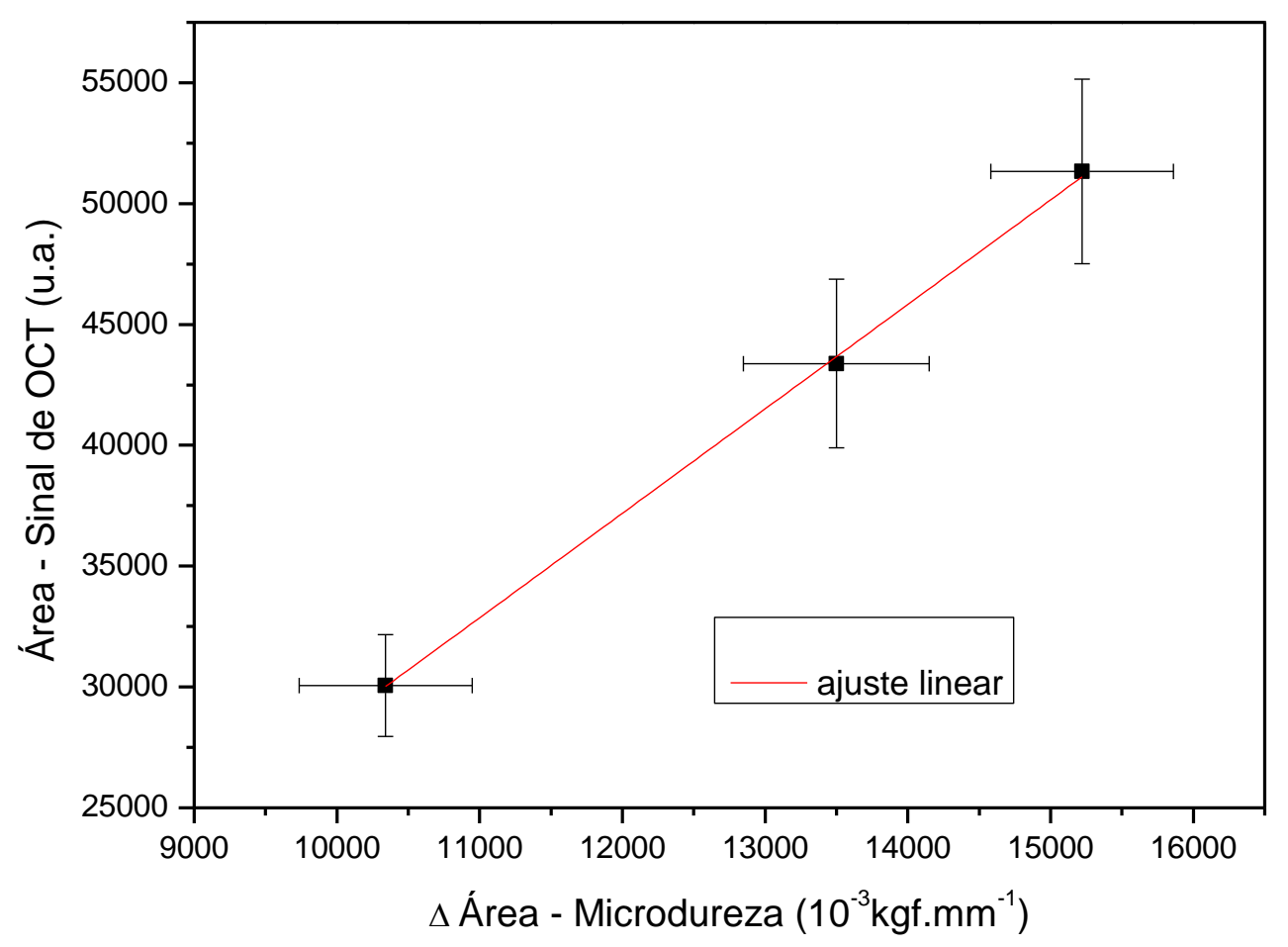

FIGURA 55: Gráfico de área sob a curva de OCT em função da diferença de áreas de microdureza entre a região sadia e desmineralizada (relacionada à perda mineral) para a profundidade aproximada de 20 a $120 \mu \mathrm{m}$ em esmalte dental. A linha vermelha representa a relação linear entre as técnicas avaliadas.

Foi observada relação de linearidade entre as técnicas analisadas e a função que relaciona os dois métodos de exame é dada por:

$$
A_{O C T}=4,32 \cdot \Delta A_{M I C}-14670,94
$$

onde $A_{O C T}$ representa a área sob a curva de sinal de intensidade de OCT pela profundidade e $\Delta A_{M I C}$ corresponde a área relacionada à perda mineral em gráficos de microdureza por profundidade.

A relação estabelecida entre as áreas de OCT e microdureza demonstra que alterações do esmalte detectadas por microdureza são detectadas 
de forma mais expressiva pela técnica de OCT, (com aproximadamente 4 ordens de magnitude a mais).

Para a profundidade de análise de 40 a $120 \mu \mathrm{m}$, a relação entre as áreas obtidas através dos gráficos de OCT e microdureza seccional, ambos em função da profundidade, está apresentada na FIGURA 56.

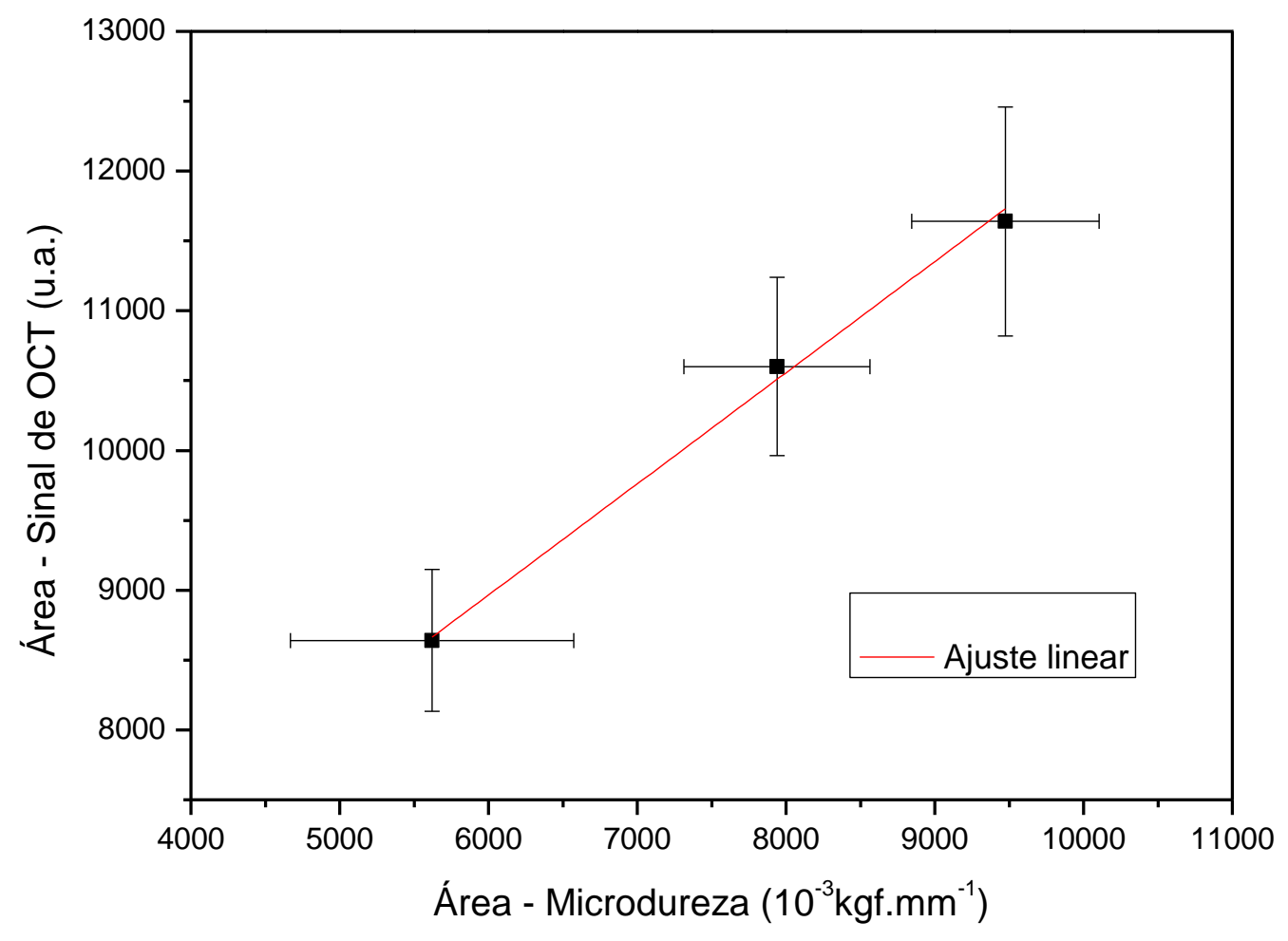

FIGURA 56: Gráfico de área sob a curva de OCT em função da diferença de áreas de microdureza entre a região sadia e desmineralizada (relacionada à perda mineral), para a profundidade de 40 a $120 \mu \mathrm{m}$ em esmalte dental. A linha vermelha representa a relação linear entre as técnicas avaliadas.

Assim como para a profundidade de 20 a $120 \mu \mathrm{m}$, foi observada relação de linearidade entre os resultados de área de microdureza e de OCT. A função que relaciona essas áreas agora é descrita por:

$$
A_{\text {OCT }}=0,79 \cdot \Delta A_{M I C}+4190,49
$$


onde, $A_{O C T}$ representa a área sob a curva de sinal de intensidade de OCT em função da profundidade e $\Delta A_{M I C}$ corresponde a área relacionada à perda mineral em gráficos de microdureza em função da profundidade.

Para a profundidade analisada (40 a $120 \mu \mathrm{m}$ ), a detecção de alterações minerais de esmalte dental, determinada através do cálculo de área de OCT é menor (aproximadamente $80 \%$ ) que a observada pela microdureza.

O estudo de variação de profundidades para análise, demonstrou que a profundidade de 20 à $120 \mu \mathrm{m}$ apresentou-se mais adequada para a determinação de processos de perda mineral, por considerar regiões mais superficiais do esmalte dental, onde ocorrem as maiores alterações de conteúdo mineral, evidenciado pela maior especificidade e sensibilidade obtidas pela análise do coeficiente de atenuação óptica. Além disso, a variação da área do sinal de OCT demonstrou ser capaz de detectar pequenas variação de área de microdureza, que neste caso é da ordem de 4 vezes maior. Para essa profundidade o poder de estudo está apresentado no APÊNDICE C. 


\section{CONCLUSÕES}

O coeficiente de atenuação óptica total foi adequado para identificar as amostras de esmalte dental desmineralizadas, com elevado grau de sensibilidade e especificidade.

O emprego da área sob a curva, obtida a partir de gráficos de intensidade de sinal de OCT em função da profundidade, como parâmetro de avaliação de perda mineral, apresentou alta correlação com os resultados de microdureza, para detecção de diferentes estágios de desmineralização. Houve relação de linearidade entre os resultados de OCT e microdureza para as profundidades de análise em esmalte dental consideradas no estudo.

A técnica de OCT foi capaz de detectar desmineralização do esmalte dental humano em lesões simuladas de cárie. A relação de linearidade observada entre as técnicas de OCT e microdureza, para detecção de desmineralização em esmalte dental, demonstra o potencial do exame de OCT na avaliação quantitativa de perda mineral, sendo uma importante ferramenta para acompanhamento de lesões de cárie em esmalte dental in vitro e in vivo, podendo ser utilizada na rotina da clínica odontológica.

Para determinação absoluta de limiar de esmalte sadio, faz-se necessário um estudo com maior número de amostras. 


\section{APÊNCICES}

\subsection{Apêndice A}

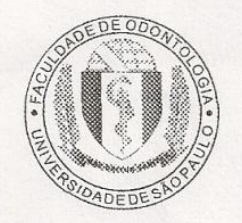

\section{UNIVERSIDADE DE SÃO PAULO \\ Faculdade de Odontologia \\ Banco de Dentes Humanos}

\section{DECLARACÃO AO COMITÊ DE ÉTICA EM PESOUISA}

Para fins de avaliação pelo Comitê de Ética em Pesquisa (CEP) dessa instituição, o Banco de Dentes Humanos da FOUSP (DIVISÃO DENTES PERMANENTES) compromete-se, mais uma vez, em auxiliar pesquisadores na realização de seus projetos.

Sendo assim, após a aprovação do CEP, nossa contribuição consistirá no oferecimento de 53 (cinqüenta e três) dentes $3^{\circ}$ molares hígidos para a execução do trabalho de pesquisa intitulado: "Avaliação do processo de desenvolvimento de desmineralização em esmalte dental utilizando a técnica de tomografia por coerência óptica" a ser realizado por Ana Claudia Ballet de Cara e orientada pelo Prof ${ }^{\circ}$ Dr. Anderson Zanardi de Freitas .

São Paulo, 26 de Março de 2010.
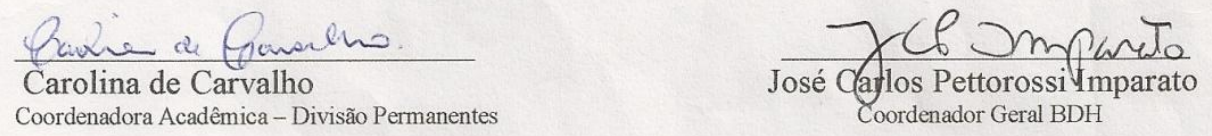

Av. Prof. Lineu Prestes,2227 - Cidade Universitária "Armando de Salles Oliveira" - CEP 05508-900São Paulo - SP - Contato: (0xx11)3091-7905 - e-mail:bdh@usp.br 


\title{
7.2 Apêndice B
}

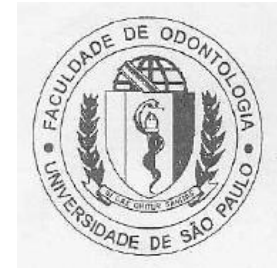

\section{UNIVERSIDADE DE SÃO PAULO FACULDADE DE ODONTOLOGIA Comitê de Ética em Pesquisa}

\author{
PARECER DE APROVAÇÃO \\ FR -360665 \\ Protocolo 153/2010
}

O grupo de trabalho indicado pelo Comitê de Ética em Pesquisa APROVOU o protocolo de pesquisa "Avaliação do processo de desenvolvimento de desmineralização em esmalte dental utilizando a técnica de tomografia por coerência óptica", de responsabilidade do(a) Pesquisador(a) Ana Claudia Ballet de Cara, sob orientação do(a) Prof.(a) Dr.(a) Anderson Zanardi de Freitas.

Tendo em vista a legislação vigente, devem ser encaminhados a este Comitê relatórios anuais referentes ao andamento da pesquisa e ao término cópia do trabalho em "cd". Qualquer emenda do projeto original deve ser apresentada a este CEP para apreciação, de forma clara e sucinta, identificando a parte do protocolo a ser modificada e suas justificativas.

São Paulo, 18 de agosto de 2010.

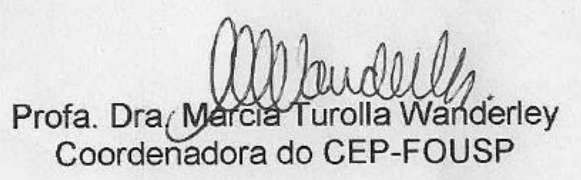

Av. Prof. Lineu Prestes, 2227 - Cidade Universitária "Armando de Salles Oliveira" CEP 05508-000 São Paulo - SP - Diretoria Telefax: (011)3091-0062/3091-7817/3091-7860 - Compras (011) 3091-7825 Impressono S.DO 


\subsection{Apêndice C}

Para o experimento final o poder do estudo obtido a partir dos coeficientes de atenuação óptica provenientes do sinal de OCT (25 a $120 \mu \mathrm{m}$ ) está representado no gráfico abaixo:

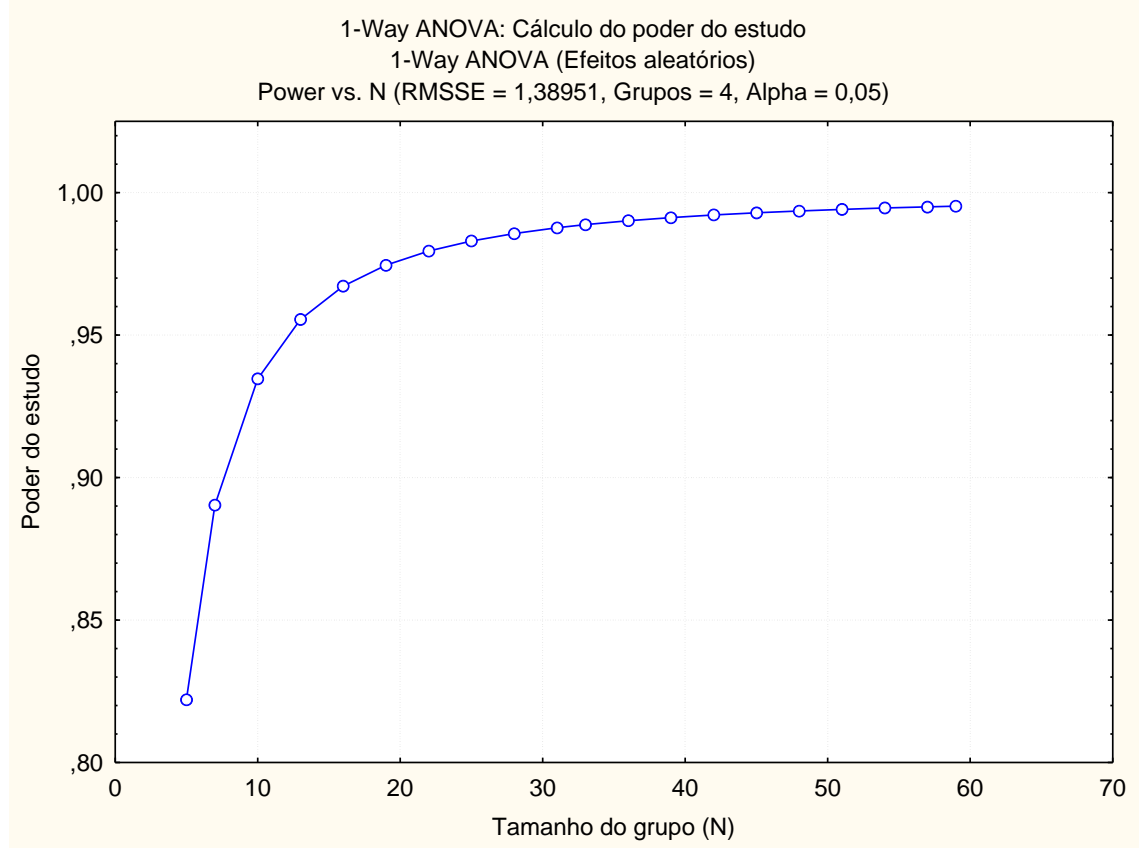

Para o experimento final o poder do estudo obtido a partir das áreas sob a curva do sinal de OCT (25 a $120 \mu \mathrm{m}$ ) está representado no gráfico abaixo:

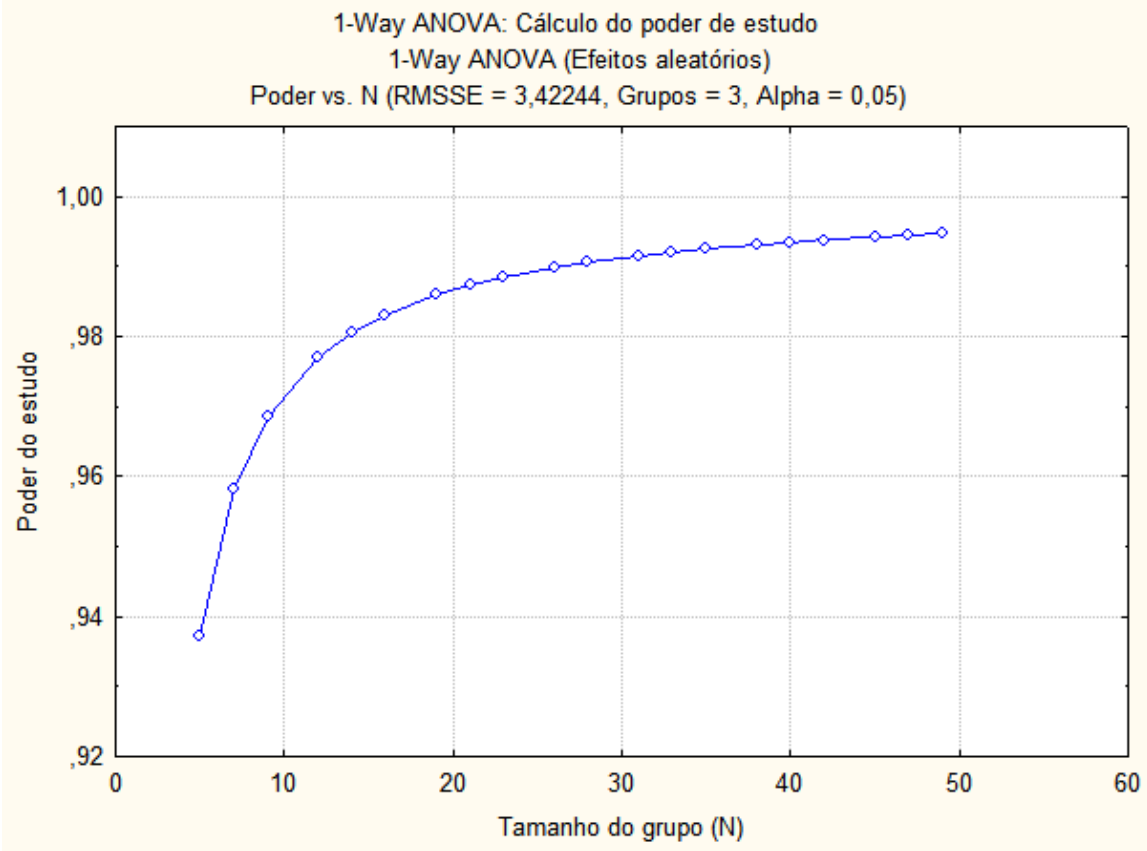

Gráficos obtidos com o programa STATISTICA. 


\section{REFERÊNCIAS BIBLIOGRÁFICAS}

${ }^{1}$ FEATHERSTONE,J. D. B. Prevention and reversal of dental caries: role of low level fluoride. Community Dent. Oral Epidemiol., v. 27, n. 1, p.31-40, 1999.

${ }^{2}$ FRIED, D.; XIE, J.; SHAFI, S.; FEATHERSTONE, J.D.B.; BREUNING, T.M.; LE, C. Imaging caries lesions and lesion progression with polarization sensitive optical coherence tomography. J. Biomed. Opt., v. 7, n. 4, p. 618-624, 2002.

3 STOOKEY, G.K.; GOZÁLEZ-CABEZAS, C. Emerging methods of caries diagnosis. J. Dent. Educ., v. 65, n. 10, p. 1001-1006, 2001.

${ }^{4}$ PRETTY, I.A. Caries detection and diagnosis: novel technologies. J.Dent., v.34, p.727-734, 2006.

${ }^{5}$ STOOKEY, G.K.; JACKSON, R.D.; ZANDONA, A.G.; ANALOUI, M. Dental caries diagnosis. Dent. Clin. North Am., v.43, n.4, p. 665-677, 1999.

${ }^{6}$ BADER, J.D.; SHUGARS, D.A. A systematic review of the performance of a laser fluorescence device for detecting caries. J. Am. Dent. Assoc., v.135, n.10, p.1413-1426, 2004

7 KO, A. C-T.; CHOO-SMITH, L-P.; HEWKO, M.; LEONARDI, L.; SOWA, M.G.; DONG, C.C.S.; WILLIAMS, P.; CHEGHORN, B. Ex vivo detection and characterization of early dental caries by optical coherence tomography and Raman spectroscopy. J. Biomed. Opt., v.10, n.3, 031118, 2005.

${ }^{8}$ FREITAS, A.Z.; ZEZELL, D.M.; VIEIRA JR, N.D.; RIBEIRO, A.C.; GOMES,. A.S.L. Imaging carious human dental tissue with optical coherence tomography. $\boldsymbol{J}$. Appl. Phys., v.99,024906, 2006. 
9 WANG, X-J.; MILNER, T.E.; BOER, J.F.; ZHANG, Y.; PASHLEY, D.H.; NELSON, J.S. Characterization of dentin and enamel by use of optical coherence tomography. Appl. Opt., v.38, n.10. p.2092-2096, 1999.

${ }^{10}$ HUANG, D.; SWANSON, E.A.; LIN, C.P.; SCHUMAN, J.S.; STINSON, W.G.; CHANG, W.; HEE, N.R.; FLOTTE, T.; GREGORY, K.; PULIAFITO, C.A.; FUJIMOTO, J.G. Optical coherence tomography. Science, v.254, p.1178-1181, 1991.

11 YOUNGQUIST, R.C.; CARR, S.; DAVIES, D. E. N. Optical coherence domain reflectometry," Appl. Opt., v. 12, p.158-160,1987.

12 SCHIMITT, J.M.; YADLOWSKY, M.; BONNER, R.F., Subsurface imaging in living skin with optical coherence tomography. Dermatol., v.191, p. 93-98, 1995.

${ }^{13}$ VASQUEZ-PINTO, L.; FREITAS, A.Z.; VIEIRA, N.; GESZTESI, J.; LEO, C. Skin histomorphological correlation with optical coherence tomography (OCT). J. Invest. Dermatol.,128: 546, 2008.

${ }^{14}$ SERGEEV, A. et al. In vivo endoscopic OCT imaging of precancer and cancer states of human mucosa. Opt. Express, v.1, n.13, p.432-440, 1997.

15 FUJIMOTO, J.G.; BREZINSKI, M.E.; TEARNEY, G.J.; BOPPART, S.A.; BOUMA, B.E.; HEE, M.R.; SOUTHERN, J.F.; SWANSON, E.A. Optical biopsy and imaging using optical coherence tomography. Nature Med. ,v. 1, p. 970-972, 1995.

${ }^{16}$ AMAECHI,B.T.; PODOLEANU, A.; HIGHAM, S.M.; JACKSON, D.A. Correlation of quantitative light-induced fluorescence and optical coherence tomography applied for detection and quantification of early dental caries. J.Biomed. Opt., v.8, n. 4, p.642-647, 2003. 
17 JONES, R.S.; DARLING, C.L.; FEATHERSTONE, J.D.B.; FRIED, D. Imaging artificial caries on the occlusal surfaces with polarization-sensitive optical coherence tomography. Caries Res., v.40, p.81-89, 2006.

${ }^{18}$ CHEN, Y.; OTIS, L.; PIAO, D.; ZHU, Q. Characterization of dentin, enamel, and carious lesions by a polarization-sensitive optical coherence tomography system. Appl. Opt., v.44, n.11, p.2041-2048, 2005.

${ }^{19}$ MAIA, A.M.; FONSECA, D.D.; KYOTOKU, B.B.; Gomes, A.S. Characterization of enamel in primary teeth by optical coherence tomography for assessment of dental caries. Int. J. Paediatr. Dent., v.20, n.2, p.158-164, 2010.

20 STANINEC, M.; DOUGLAS, S.M.; DARLING, C.L.; CHAN,K.; KANG, H.; LEE, R.C.; FRIED, D. Non-destuctive clinical assessment of occlusal caries lesions using near-IR methods. Lasers Surg. Med., v.43, p.951-959, 2011.

${ }^{21}$ RAELE, M.P. Desenvolvimento de um sistema de tomografia por coerência óptica no domínio de Fourier sensível á polarização e sua utilização na determinação das matrizes de Mueller. 2009 Dissertação (Mestrado) - Instituto de Pesquisas Energéticas e Nucleares, São Paulo.

22 JONES, R.S.; FRIED, D. Remineralization of enamel caries can decrease optical reflectivity. J. Dent. Res., v.85, n.9, p.804-808, 2006.

${ }^{23}$ FEATHERSTONE, J.D.B.; O'REILLY, M.M.; SHARIATI, M.; BRUGLER, S. Enhancement of remineralization in vitro and in vivo. In: Leach SA. Factors affecting de- and remineralization of the teeth. Oxford: IRL Press, p. 23-34, 1986.

${ }^{24}$ ARGENTA, R.M.O.; TABCHOURY, C.P.M.; CURY, J.A. A modified pH-cycling model to evaluate fluoride effect on enamel demineralization. Pesqui. Odontol. Bras., v.17, n.3, p.241-246, 2003. 
${ }^{25}$ REHDER NETO, F.C.; MAEDA, F.A.; TURSSI, C.P.; SERRA, M.C. Potential agents to control enamel caries-like lesions. J. Dent., v.37, n.10, p. 786-790, 2009.

${ }^{26}$ KIELBASSA, A.M.; WRBAR, K.T.; SCHULTE-MÖNTING, J.; HELLWIG, E. Correlation of transversal microradiography and microhardness on in situ-induced demineralization in irradiated and nonirradiated human dental enamel. Arch. Oral Biol., v.44, n.3, p.243-251, 1999.

${ }^{27}$ KO, C.C.; TANTBIROJN, D.; WANG, T.; DOUGLAS, W.H. Optical scattering power for characterization of mineral loss. J. Dent. Res., v.79, n.8, p.1584-1589, 2000.

${ }^{28}$ KATCHBURIAN, E.; ARANA, V. Esmalte. In: KATCHBURIAN, E.; ARANA, V. Histologia e embriologia oral. Guarulhos, SP.:Panamericana, 1999. p.238-279.

${ }^{29}$ CHADWICK.D.J., CARDEW,G. Dental enamel. London, UK:Chichester Wiley, 1997.

30 YOUNG,R.A.Biological apatite vs hydroxyapatite at the atomic level. Clin. Orthop.Relat. Res., v.113, p.249-262,1075.

31 LEGEROS,R.Z. Calcium phosphates in demineralization/remineralization process. J.Clin. Dent. v.10, n.2, p.65-73, 1999.

32 FRANK,R.M. Tooth enamel:current state of the art. J. Dent. Res., v.58, n.spec issueB,p.684-694, 1979.

${ }^{33}$ NEWBRUN,E. Cariology. Baltimore, Maryland:Williams \&Wilkins, 1978.

${ }^{34}$ FEATHESTONE, J.D., ROSENBERG,H. Lipid effect on the progress of artificial carious lesions in dental enamel. Caries Res., v. 18, n.1, p.52-55, 1984. 
AOBA, T. Solubility properties of human tooth mineral and pathogenesis of dental caries. Oral Dis., v.10, n.5, p.249-257, 2004.

36 THYLTRUP. A.; FEJEKSKOV. O. Cariologia Clínica. 3 ed. São Paulo, S.P.: Editora Santos, 2005.

37 FERSJESKOV, O.; KIDD. E. Cárie dental: a doença e seu tratamento clínico. São Paulo, S.P.: Editora Santos, 2005.

38 FEATHESTONE, J.D. Dental caries: a dynamic disease process. Australian Dent. J., v.53, n.3, p.286-291, 2008.

${ }^{39}$ CURY, J.A. Uso do flúor e controle da cárie como doença. In: BARATIERI, L.N. et al. Odontologia Restauradora: Fundamentos e possibilidades. São Paulo, S.P.: Editora Santos, p.33-68, 2001.

40 CURY, J.A.; TENUTA, L.M.A. How to maintain a cariostatic fluoride concentration in the oral environment. Adv. Dent. Res., v.20, n.1, p.13-16, 2008.

${ }^{41}$ PITTS, N.B. Clinical diagnosis of dental caries: a european perspective. J. Dent. Educ., v.65, n.10, p.972-978, 2001

42 AL-KHATEEB, S.; TENCATE, J.M.; ANGMAR-MANSSON, B.; JONG, E.J.; SUNDSTRON, G.; EXTERKATE, R.A.M.; OLIBEBY, A. Quantification of formation and remineralization of artificial enamel lesions with a new portablefluorescence device. Adv. Dent. Res., v.11, n.4, p.502-506, 1997.

${ }^{43}$ BOUMA, E.B.; TEARNEY, G. J. Handbook of optical coherence tomography. New York, N.Y.:Marcel Dekker, 2002. 
${ }^{44}$ FREITAS, A.Z.; AMARAL, M.M.; RAELE, M.P. Optical Coherence Tomography: Development and Applications In: DUARTE, F.J. Laser Pulse Phenomena and Applications. Rijeka: InTech, 2010, p. 409-432.

${ }^{45}$ FERCHER, A.F.; DREXTER, W.; HITZENBERGER, C.K.; LASSER, T. Optical coherence tomography - principles and applications. Rep. Prog. Phys., v. 66, p.239-303, 2003.

${ }^{46}$ POPESCU, D.P.; SOWA, M. G.; HEWKO, M. D.; CHOO-SMITH, L. P. Assessment of early demineralization in teeth using the signal attenuation in optical coherence tomography images. J. Biomed. Opt., v.13, n.3, 054053, 2008.

47 AZEVEDO, C.S.: TRUNG. L.C.E.; SIMIONATO, M.R.L.; FREITAS, A.Z.; MATOS, A.B. Evaluation of caries-affected dentin with optical coherence tomography. Braz. Oral. Res., v.25, n.5, p.407-13, 2011.

${ }^{48}$ COLSTON, B.W.; EVERETT, M.J.; DA SILVA, L.B.; OTIS, L.L.; STROEVE, P.; NATHEL, H. Imaging of hard- and soft-tissue structure in the oral cavity by optical coherence tomography. Appl. Opt., v.37, n.16, p.3582-5, 1998.

49 BAKHMUTOV, D.; GOUNCHUKOV, S.;KLARCHENKO, O.; VOIOTENOK, O.; ZUBOV, B. Early caries naked-eyed examination. Laser Phys. Lett., v.5, n.5, p.375-8, 2008.

50 MUJAT, C.; VAN DER VEEN, M.H.; RUBEN, J.L.; TEN BOSCH, J.J.; DOGARIU, A. Optical path-length spectroscopy of incipient caries lesions in relation to quantitative light induced fluorescence and lesions characteristics. Appl. Opt., v.42, n.16, p. 2079-2086, 2003.

51 BAUMGARTNER, A.; DICHT, S; HITZENBERGER, C.K.;SATTMANN, H.; ROBI, B.; MORITZ, A.;SPERR, W.; FERCHER, A.F. Polarization-sensitive optical coherence tomography of dental structures. Caries Res., v.34, p.59-69, 2000. 
${ }^{52}$ SOWA, M.G.; POPESCU, D.P.; FRIESEN, J.R.; HEWKO, M. D.; CHOO-SMITH, L. P. A comparision of methods using optical coherence tomography to detect demineralized regions in the teeth. J. Biophotonics, v.4, n.11-12, p.814-823, 2001.

53 FEATHERSTONE, J.D.; TEN CATE, J.M.; SHARIATI, M.; ARENDS, J. Comparison of artificial caries-like lesions by quantitative microradiography and microhardness profiles. Caries Res., v.17, n.5, p.385-391, 1983.

${ }^{54}$ COSTA NETO, P.L.O. Estatística. 2 ed. São Paulo, S.P.: Editora Edgard Blucher, 2002.

${ }^{55}$ NIST/SEMATECH e-Handbook of Statistical Methods. Engineering Statistics Handbook. http://www.itl.nist.gov/div898/handbook/index.htm. Acesso em: 30 jan. 2012. 